Portland State University

PDXScholar

Master of Environmental Management Project

Reports

Environmental Science and Management

Fall 2019

\title{
Watershed Assessment of Tryon Creek of Oregon
}

Danielle Goodrich

Portland State University

Follow this and additional works at: https://pdxscholar.library.pdx.edu/mem_gradprojects

Part of the Environmental Indicators and Impact Assessment Commons, and the Environmental Monitoring Commons

Let us know how access to this document benefits you.

\section{Recommended Citation}

Goodrich, Danielle, "Watershed Assessment of Tryon Creek of Oregon" (2019). Master of Environmental Management Project Reports. 57.

https://pdxscholar.library.pdx.edu/mem_gradprojects/57

https://doi.org/10.15760/mem.59

This Project is brought to you for free and open access. It has been accepted for inclusion in Master of Environmental Management Project Reports by an authorized administrator of PDXScholar. Please contact us if we can make this document more accessible: pdxscholar@pdx.edu. 


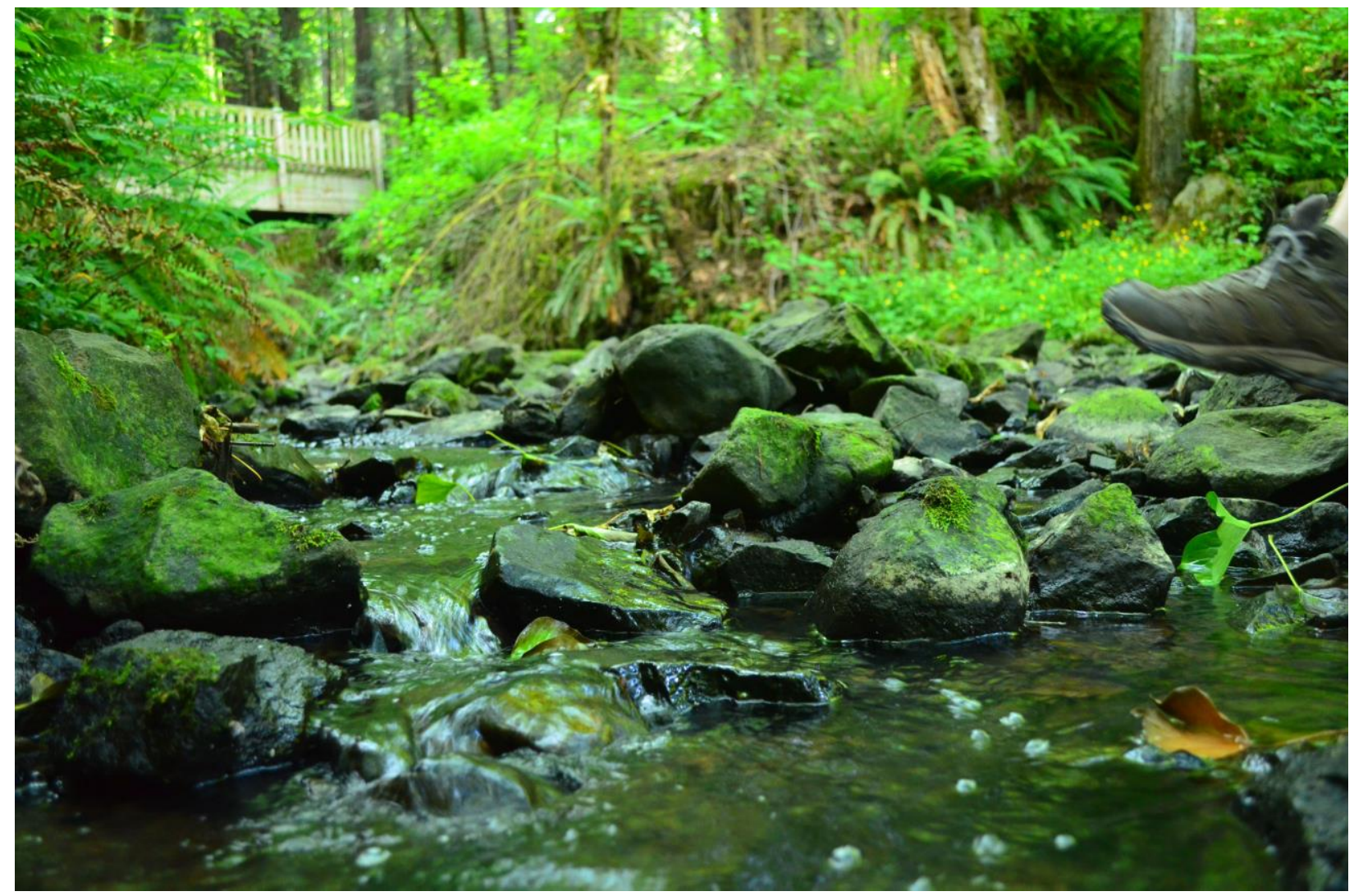

(Source: Barton, A. (2019). Tryon Creek Watershed Council)

\section{Watershed Assessment of Tryon Creek of Oregon}

This document was written in cooperation with the Tryon Creek Watershed Council by Danielle Goodrich as a master's project for the Professional Science Master of Environmental Science and Management degree at Portland State University, Oregon. 


\title{
Watershed Assessment of Tryon Creek of Oregon Tryon Creek Watershed Council
}

\author{
December 17, 2019
}

\section{Acknowledgements}

Thank you to all of the board members and partners of the Tryon Creek Watershed Council for providing this project opportunity and for your dedication to stewardship of the watershed. Glen Leverich, Dusty Day, Terri Preeg Riggsby, Alexis Barton, Sharon Keast, Carl Axelsen, Megan Hill, Jennifer Jones, Hannah Machiorlete, and Torrey Lindbo have contributed incomparable efforts to this watershed assessment and Tryon Creek as a whole. Thank you, Dr. Joseph Maser, very much for guiding this project and providing key insight. Thank you, Dr. Patrick Edwards, for being a member of my review committee and serving as a role model for me during my graduate work. A final thank you goes to all of the folks who provided resources and guidance throughout this process, including Jim Cathcart and colleagues at West Multnomah Soil and Water Conservation District, Colleen Mitchell and colleagues at the City of Portland, Bureau of Environmental Services, Sonja Johnson and colleagues at City of Lake Oswego, Erin Cathcart, Gabe Sheoships, and colleagues at Friends of Tryon Creek, Andrea Berkley and colleagues at Oregon Parks and Recreation Department, Andrea Matzke and colleagues at Oregon Department of Environmental Services, Brook Silver and colleagues at United States Fish and Wildlife Services, Adam Stonewall and colleagues at United States Geological Survey, Monica Blanchard and colleagues at Oregon Department of Fish and Wildlife, and Lori Hennings and colleagues at Metro. 


\section{LIST OF COMPONENTS}

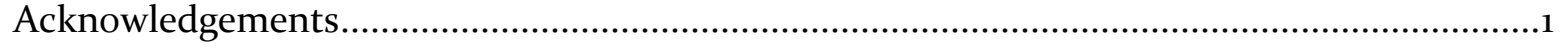

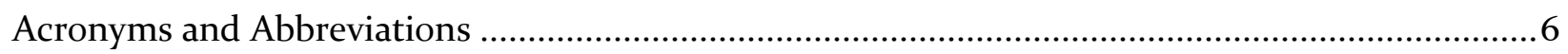

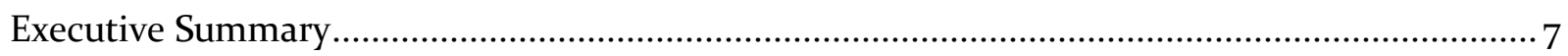

I. Introduction of the Watershed Assessment .................................................................... 11

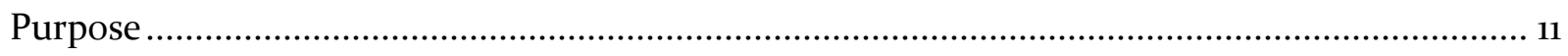

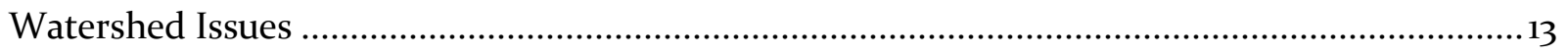

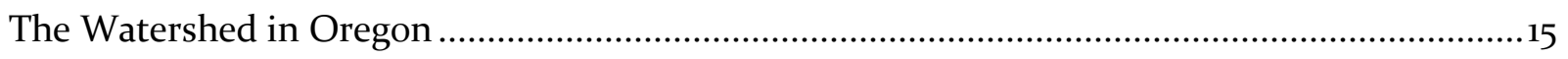

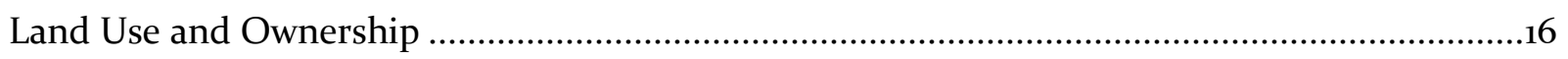

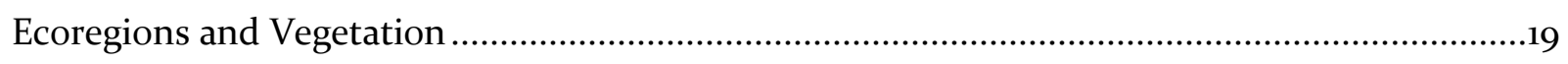

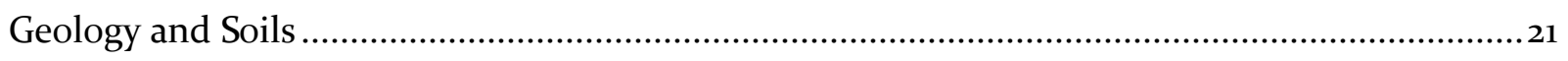

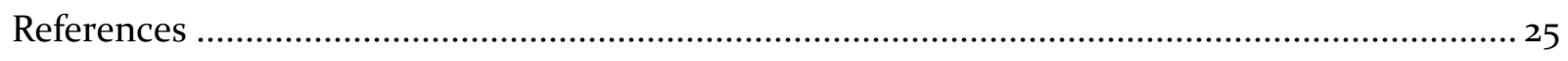

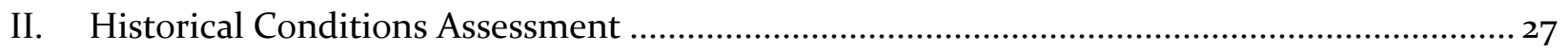

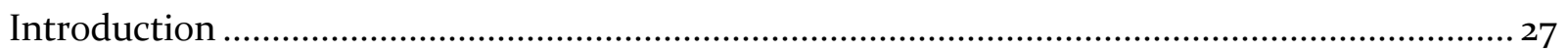

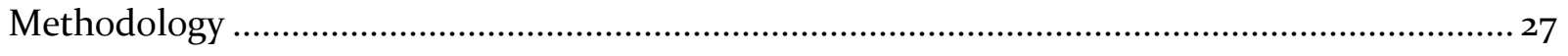

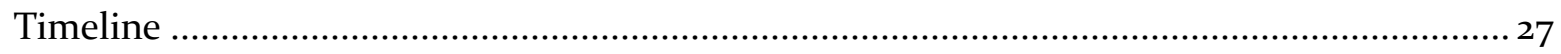

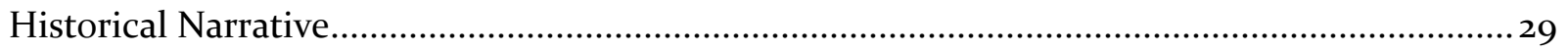

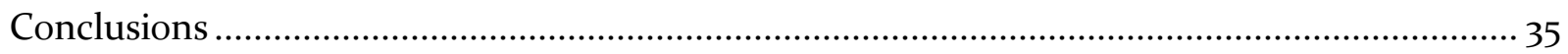

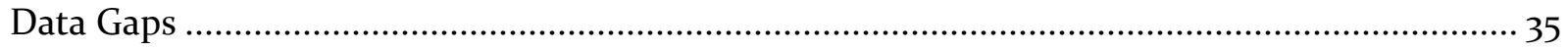

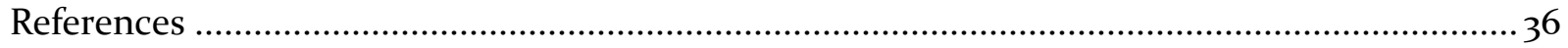

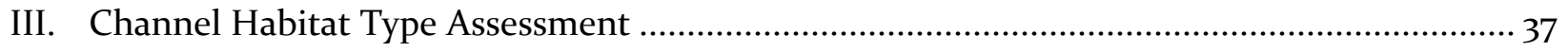

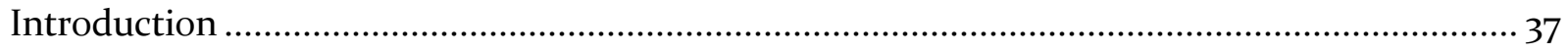

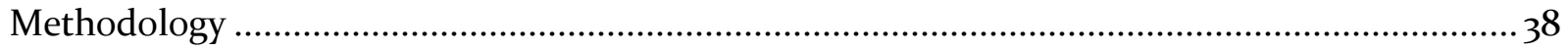

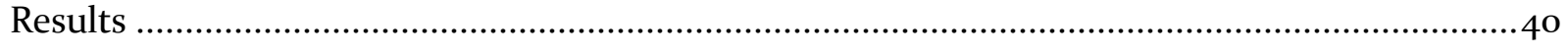

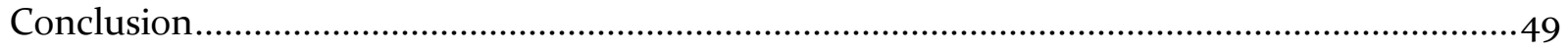

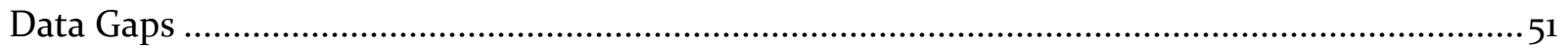

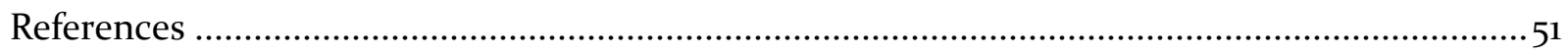

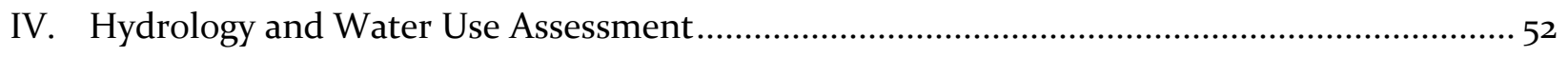

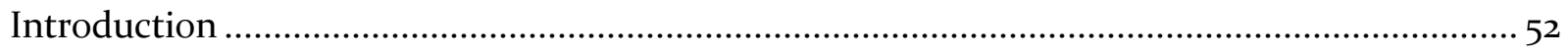

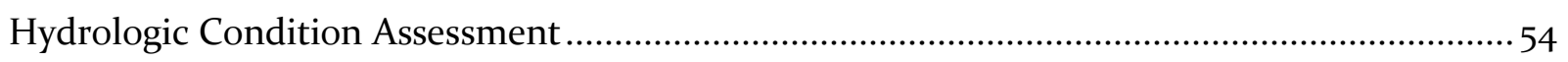

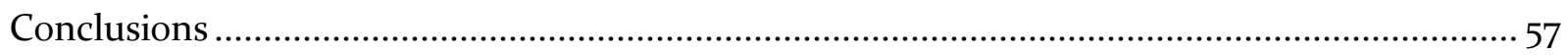

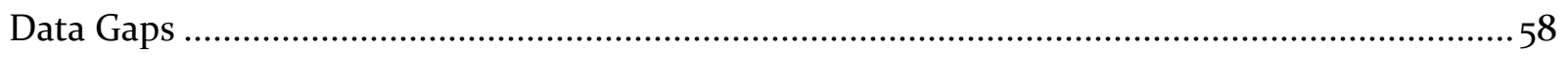

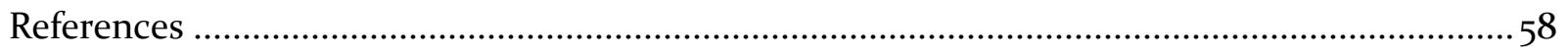

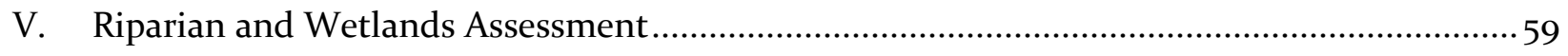

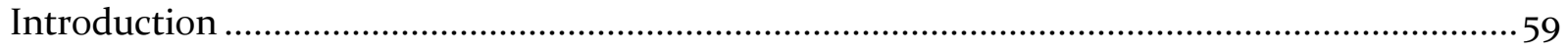




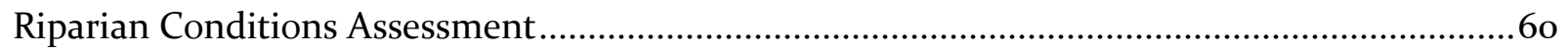

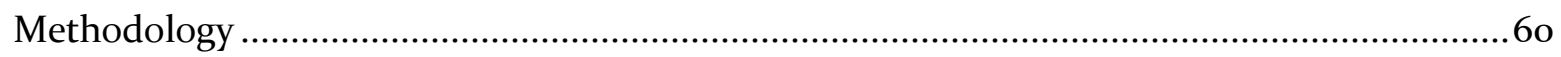

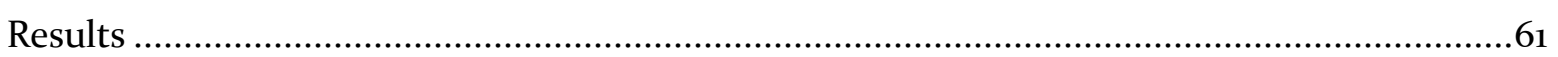

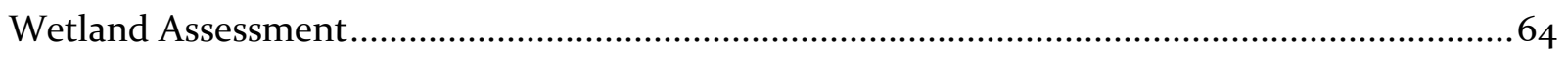

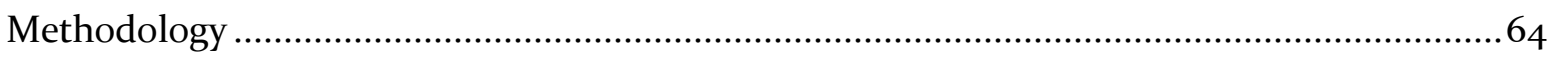

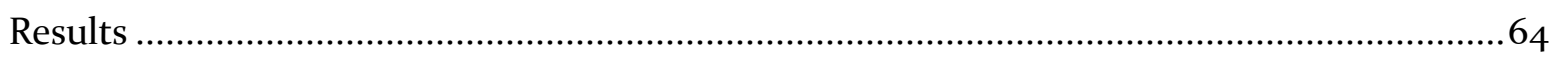

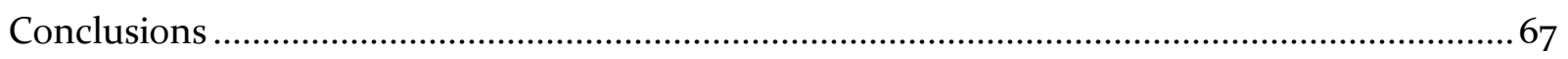

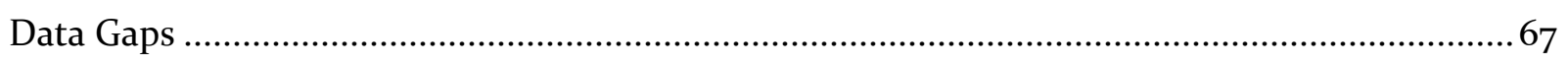

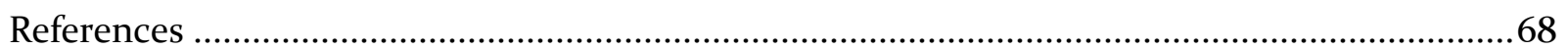

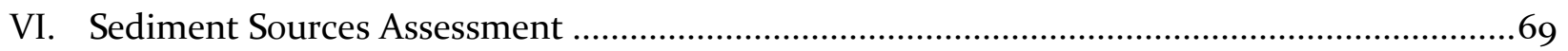

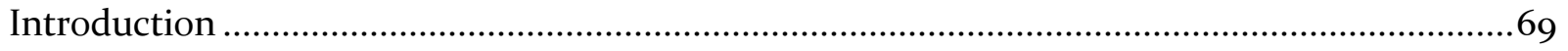

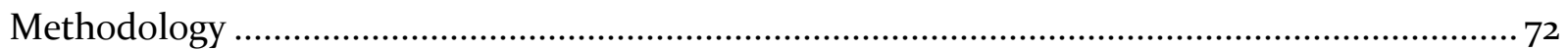

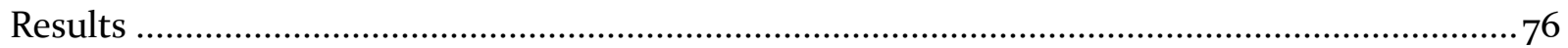

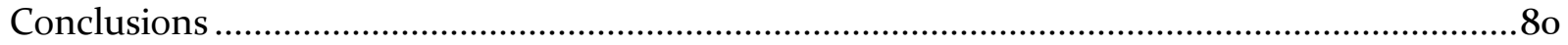

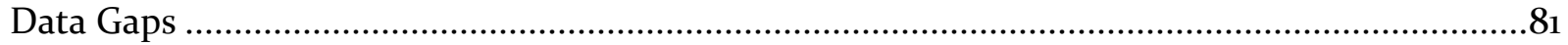

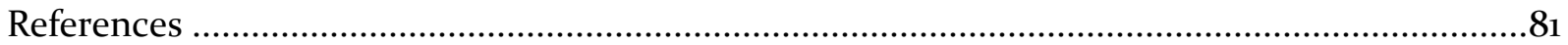

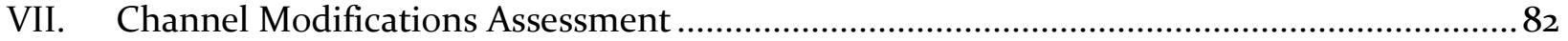

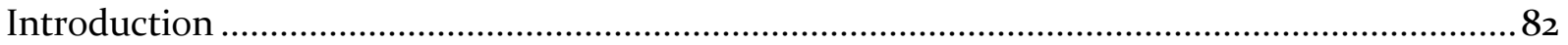

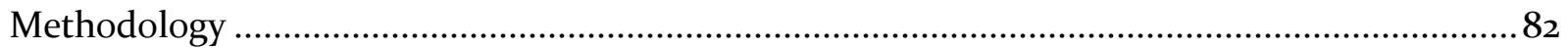

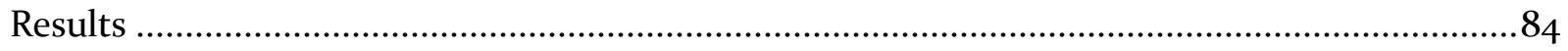

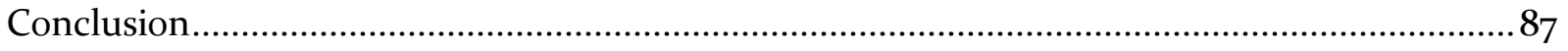

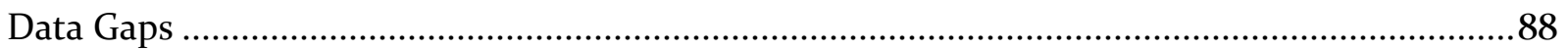

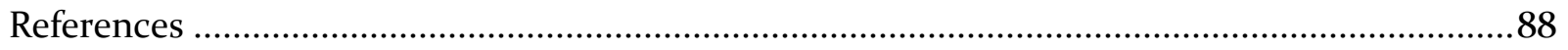

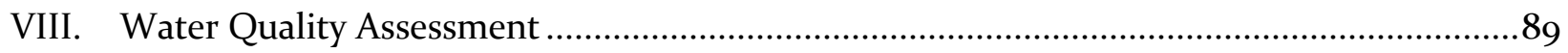

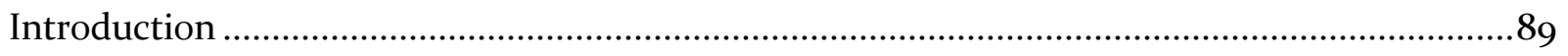

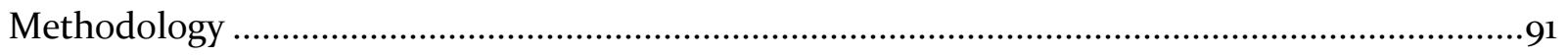

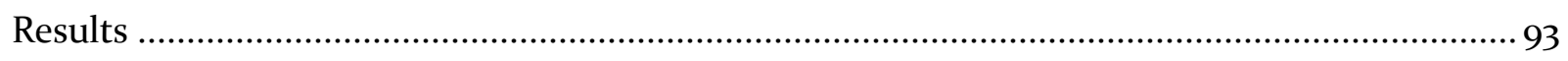

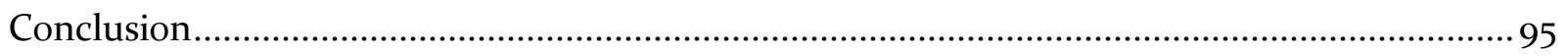

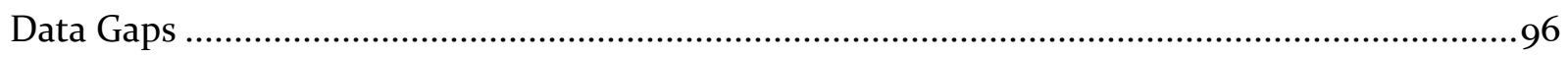

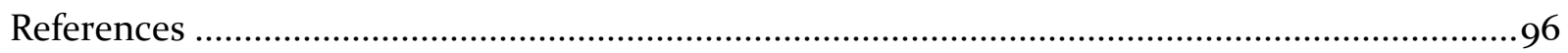

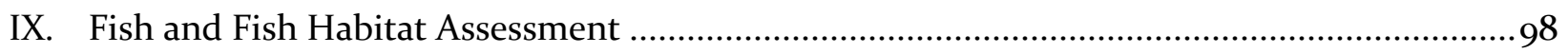

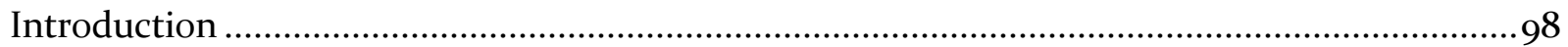

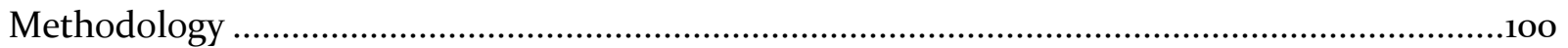

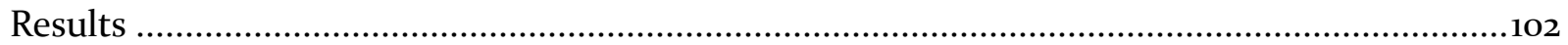

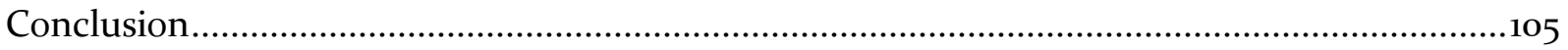




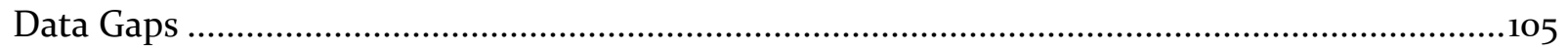

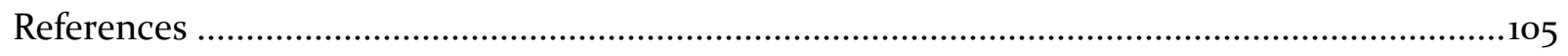

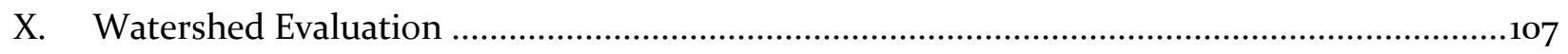

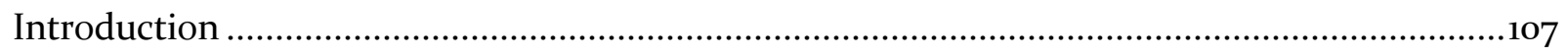

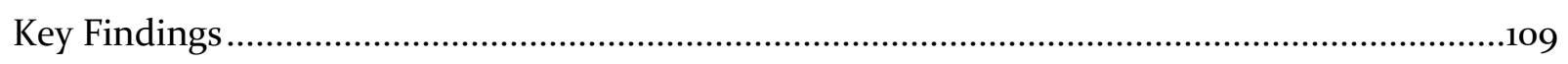

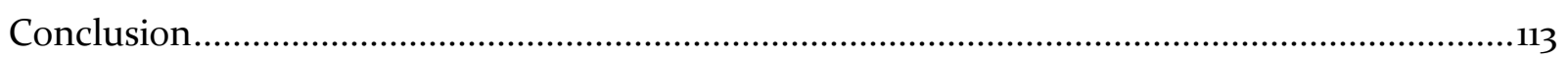

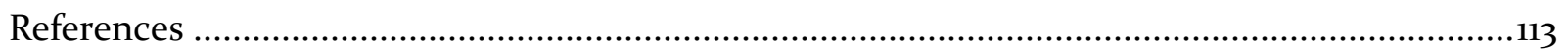




\section{ACRONYMS AND ABBREVIATIONS}

$\begin{array}{ll}\text { BES } & \text { [City of Portland] Bureau of Environmental Science } \\ \text { BLM } & \text { [United States] Bureau of Land Management } \\ \text { BMP } & \text { Best Management Practices } \\ \text { CFS } & \text { Cubic feet per second } \\ \text { CRBG } & \text { Columbia River Basalt Group } \\ \text { CWA } & \text { Clean Water Act } \\ \text { DEQ } & \text { Department of Environmental Quality } \\ \text { DMA } & \text { Designated Management Agency } \\ \text { EPA } & \text { Environmental Protection Agency } \\ \text { ESA } & \text { Endangered Species Act } \\ \text { HUC } & \text { Hydrologic Unit Codes } \\ \text { HWY } & \text { Highway } \\ \text { LWD } & \text { Large Woody Debris } \\ \text { MS4 } & \text { Municipal Separate Storm Sewer Systems } \\ \text { MCF } & \text { Marine Western Coastal Forest } \\ \text { NMFS } & \text { National Marine Fisheries Service } \\ \text { NOAA } & \text { National Oceanic and Atmospheric Administration } \\ \text { NPDES } & \text { National Pollutant Discharge Elimination System } \\ \text { NRCS } & \text { Natural Resources Conservation Service } \\ \text { NWI } & \text { National Wetland Inventory } \\ \text { ODFW } & \text { Oregon Department of Fish and Wildlife } \\ \text { ODOT } & \text { Oregon Department of Transportation } \\ \text { OPRD } & \text { Oregon Parks and Recreation Department } \\ \text { OWEB } & \text { Oregon Watershed Enhancement Board } \\ \text { OWQI } & \text { Oregon Water Quality Index } \\ \text { PAWMAP } & \text { Portland Area Watershed Monitoring and Assessment Program } \\ \text { PBI } & \text { Pacific Biodiversity Institute } \\ \text { PBOT } & \text { Portland Bureau of Transportation } \\ \text { RM } & \text { River mile } \\ \text { TCWC } & \text { Tryon Creek Watershed Council } \\ \text { USFWS } & \text { United States Fish and Wildlife Service } \\ \text { USGS } & \text { United States Geologic Survey } \\ & \end{array}$




\section{Executive Summary}

Introduction

As the Tryon Creek Watershed Council (TCWC) continues to grow its organization, it is important to focus their efforts on lasting changes that most positively affect the watershed. The TCWC plays a community-appointed role as the binding element of agency and stakeholder partnerships throughout the Tryon Creek watershed by providing communication and cooperation. The watershed assessment aims to provide a compilation of existing data as well as an identification of data gaps and recommendations for future cooperative management of the watershed. Developing an understanding of the processes that shape the watershed can shed light on the status of measurable ecosystem resources, including the water quality and fish habitat, as well as measure the impacts of land management practices. An understanding of the role that restoration and protection play is important as the TCWC prioritizes future actions.

\section{Historical Conditions Assessment}

The purpose of recalling historic events of the watershed are to learn how humans have interacted with Tryon Creek and its resources to help us learn about its current conditions. The first human inhabitants of the Tryon Creek are those of the Clackamas Chinook, the WascoWishram, the Willamette Tumwater, the Multnomah, and other Chinookan peoples, as well as the Tualatin Kalapuya, the Cayuse, the Molalla and other tribes and bands of the Columbia and Willamette Rivers. Records of these people and their activities relevant to the history of the watershed are unfortunately sparse. It is suggested that local organizations prioritize the effort of learning about native inhabitants of Tryon Creek and the surrounding area through oral history and research. Further land settlement then began in the mid-1850s when families, including that of Socrates Tryon, were given land through the Donation Land Claim Act. Logging soon began to support the local iron smelting operations which sparked the development of Lake Oswego as a home for industry workers prior to being rebranded as a vacation spot for Portlanders in the early 190os. Through this time, sections the creek were diverted through pipes and culverts that continue to impact the habitat today. As development continued, neighbors came together to protect the forest within Tryon Creek State Natural Area in the 1970s, contributing to the health of the watershed. Today, local agencies and organizations, such as the Tryon Creek Watershed Council, focus efforts on the stewardship of the watershed through naturalization of stream segments and riparian vegetation work.

\section{Channel Habitat Types Assessment}

The application of stream classification systems for the characterization of the effects of land uses, and guidance for stream restoration and protection. Characteristics observed throughout the stream channel are steep slopes, channel incision, and bank degradation. These characteristics can be attributed to the presence of impactful development within a watershed that has steep slopes and prone to landslides. Additionally, throughout sections of the watershed, the stream corridor is lined with landscaping and impervious surfaces that indirectly alter the structure of the stream bank. Actions that can restore channel structure toward a more natural state include improvement of channel meandering and daylighting at the headwaters and confluence. These are sections of the creek that have been most impacted by development through stream piping and diversion.

\section{Hydrology and Water Use Assessment}

In many cases, disturbances to the natural hydrological cycle cause downstream effects on a watershed, making it important to study the hydrology and water use of Tryon Creek. Understanding of hydrologic processes and land use effects are important for further ability to predict summer water temperatures, sediment transport, and other watershed geomorphic 
functions. The main issue associated with the hydrologic process of Tryon Creek is occurrence of peak flows during storms and low flows during dry months. Stormwater drainage patterns in the watershed influence the stream to have high flows following rain or storm events. This leads to erosion, introduction of sediments, and transport of woody debris and other habitat-forming materials. Low summer flows are harmful for fish and other species that rely on pool features for survival. Urban and residential land use have increased the frequency of high and low flows throughout the year. Restoration of stormwater drainage and inclusion of rain gardens and other beneficial infrastructure will benefit the health of Tryon Creek. Additionally, water rights data should be updated to include active diversions of water, including private landowner ponds and channels.

\section{Riparian and Wetlands Assessment}

This section aims to apply assessment methods to the understanding of the connections between the riparian zone, wetland areas, and the creek. Riparian vegetation is important for the biodiversity of the terrestrial aspect of a watershed as well as health of the stream. Benefits of intact riparian areas and wetlands for the stream include shading and providing large woody debris. Historic logging and recent development have altered the riparian environment, leaving the current primary canopy cover within the Tryon Creek State Natural Area being big leaf maple, Douglas fir and young to mid-aged western red cedar. Natural riparian habitat restoration is a large focus of the Tryon Creek Watershed Council (TCWC) and other local organizations throughout the watershed. The TCWC hosts events throughout the year to remove and replace invasive species, including the prolific English ivy. Ivy can overgrow trees and other vegetation, eventually smothering ground cover and felling trees due to the weight of biomass. It is suggested that land managers target ivy growing up tree trunks and smothering ground cover. Sensitive areas would be those with more recent introductions of the invasive plant species as well as those with heavy traffic and likelihood of spreading "hitchhiker" plants via boots or clothing. In addition to benefitting the riparian environment, community events targeted at invasive species removal educate residents and encourage them to continue to remove invasive species within their own properties. Riparian integrity is decreased in areas of concentrated development, especially the headwaters. Projects to remove invasive plant species and plant natives are key for enhancement of a diverse riparian habitat. Biodiversity and significant wetland environment are richest within the boundaries of the Tryon Creek State Natural Area. Wetlands assist with water storage as well as habitat for diverse plant and animals. Segments of the watershed that would most benefit from restoration of wetland habitat are the channeled headwaters and the confluence. It is suggested that the watershed council educate residents and help them to manage their land in ways that encourage meandering and wetland preservation. Native plant and terraced landscaping would increase water storage within the soil, rather than draining directly to the stream.

\section{Sediment Sources Assessment}

Within an urban watershed, there are many natural and anthropogenic sources of sediment that should be studied as they affect the stream habitat. Tryon Creek is susceptible to sediment transport due to steep slopes, channel confinement, and concentrated development. Stormwater drainage diverted to the creek without water storage or filtration carries sediment and pollutants from roadways and other impervious surfaces. Fine sediments negatively impact aquatic organisms through smothering of rock surfaces and eggs as well as decreasing visibility. Many projects by the City of Portland target improvement of roadways and parking lots to increase water storage and filtration as it moves downstream to the creek. Recommendations for reduction of impacts of fine sediments include conservation of productive riparian environments and improvement of 
stormwater drainage from public and private facilities. Bio-swales and rain gardens provide water storage and filtrations for the runoff before entering the stream system.

\section{Channel Modifications Assessment}

The degree of impact from in-channel structures and activities can vary depending on the type of channel and the features of the modification itself. Development of Tryon Creek historically occurred without consideration of the health of the watershed and its aquatic organisms. The creek has been diverted through piping and culverts throughout its length. The culverts of Boones Ferry $\mathrm{Rd}$ and Hwy 43 have been identified as highly impactful for fish passage and are prioritized for improvement. When planning replacement of culverts, it is also important to consider challenges that the creek may face as a result. Sediment currently held in place upstream of culverts will be disturbed and washed downstream. Relocation of lamprey and other sediment dwelling organisms may reduce negative population impacts during construction of the Hwy 43 culvert. Restructuring of these culverts, daylighting sections, and improvement of floodplains would benefit the health of the aquatic habitat of Tryon Creek. Specifically, the headwaters of Tryon Creek were largely disregarded during development, leading to piping of stream channels that should be day-lighted to be enjoyed by the wildlife and human community. The confluence with the Willamette River is a section of the creek that has been channelized and would benefit from meandering and rehabilitation of the floodplain zone. This restoration would increase storm resilience by giving water more space to flow before flooding residential areas as well as provide key habitat for aquatic organisms.

\section{Water Quality Assessment}

Studying the beneficial uses and water quality status of a creek sheds light on its health and habitability for sensitive aquatic organisms. Tryon Creek is 303(d) listed for biological criteria, dissolved oxygen, and temperature. Sensitive beneficial uses of the watershed include salmon spawning and rearing which are highly responsive to changes of these factors. Projects to decrease temperature maximums should focus on increasing riparian vegetation shading, especially in urban areas of the watershed. Preservation of cool temperatures at the headwaters through shading riparian environment and healthy stream habitat will have downstream effects on water temperature. Through efforts to encourage a native riparian environment and allowing the stream to meander naturally on private and public land surrounding the stream, temperature, dissolved oxygen, and other water quality parameters would benefit. Additionally, protection of the environment within the state natural area would continue to serve as a positive impact on the entire watershed. The dissolved oxygen and biological criteria parameters have less data to steer restoration priorities. Yet, colder, fast moving water with few pollutant influences can typically retain more oxygen indicating that stormwater drainage improvements and channel restoration would also be effective for the purpose of increasing dissolved oxygen.

\section{Fish and Fish Habitat Assessment}

One of the indicators for watershed health used in this assessment is the presence of fish, specifically salmonid species, and their habitats. Salmonid and other fish species are observed in Tryon Creek downstream of the Hwy 43 culvert and it is concluded that they would move upstream if given the opportunity. Larval lamprey were also caught downstream of the Hwy 43 culvert during samples between 2005 and 2012. The primary action that would benefit salmon distribution throughout Tryon Creek would be restructuring of the Hwy 43 and Boones Ferry Road culverts. Removing this fish passage barrier would provide habitat and other useful resources to key species that historically used Tryon Creek for habitat. Improvement of channel complexity will also make the stream more habitable through maintenance of large woody debris and pool-riffle options. 
Another suggestion for retention of stream structure is the survey of and encouragement of beaver habitat. 


\section{INTRODUCTION OF THE WATERSHED ASSESSMENT}

\section{Purpose}

As the Tryon Creek Watershed Council (TCWC) continues to grow its organization, it is important to focus their efforts on lasting changes that most positively affect the watershed. The TCWC plays a community-appointed role as the binding element of agency and stakeholder partnerships throughout the Tryon Creek watershed by providing communication and cooperation. In this role, the board of the council aims to serve their community in a positively impactful way. The most recent strategic plan of the TCWC, completed in 2017, included a need for a watershed assessment to gain an understanding of the processes that drive the watershed. An assessment of this manner would provide a compilation of existing data as well as an identification of data gaps and recommendations for future cooperative management of the watershed. An understanding of the role that restoration and protection play is important as the TCWC prioritizes future actions.

A watershed assessment is a tool used by watershed councils and other agencies to aid in the identification of key features and the understanding of processes that characterize the watershed. The benefit of conducting assessments at the watershed level is the recognition of physical connections between tributaries and the stream, surface water and groundwater, and wetlands and the water sources that feed them. Developing an understanding of the processes that shape the watershed can shed light on the status of measurable ecosystem resources, including the water quality and fish habitat, as well as measure the impacts of land management practices. The assessment technique applied to Tryon Creek was developed by the State of Oregon with the goal of evaluating the natural and anthropogenic processes that occur within a watershed and how best to manage the land for the benefit of the future of watershed health and function (Watershed Professionals Network, 1999). The process of reviewing the history of the watershed, describing its resources, features, and human influences, and identifying key issues, ultimately leads to the evaluation of how a watershed works. Through this process, a watershed council and its partners can determine management priorities for the watershed in its current condition.

The Oregon Watershed Assessment of Aquatic Resources manual compiled by the Oregon Watershed Enhancement Board (OWEB) inspired the structure of this watershed assessment. One of the main goals of the manual was to provide guidance for the interpretation of watershed health and prioritization of watershed stewardship efforts through the use of water quality and fish habitat as indicators for the health of a watershed. In addition to the introduction, the manual is composed of ten assessment components: historical conditions, channel habitat types, hydrology and water use, riparian and wetlands, sediment sources, channel modification, water quality, fish and fish habitat, and watershed condition evaluation. Emphasis is placed on the evaluation of existing data and broad-scale patterns alongside local knowledge to plan further data collection and stewardship projects. It is important to note that the watershed assessment manual was designed for watersheds of around 60,000 acres, which is about 14 times the size of the Tryon Creek watershed. Figure 1.1 displays Tryon Creek highlighted in dark blue, which is clearly much smaller than many of the major watersheds and sub-watersheds of Oregon that are also shown in the state map. This size discrepancy between the intended use of the assessment manual and its application here will lead to some alterations of the application of the methods to a more appropriate format. 


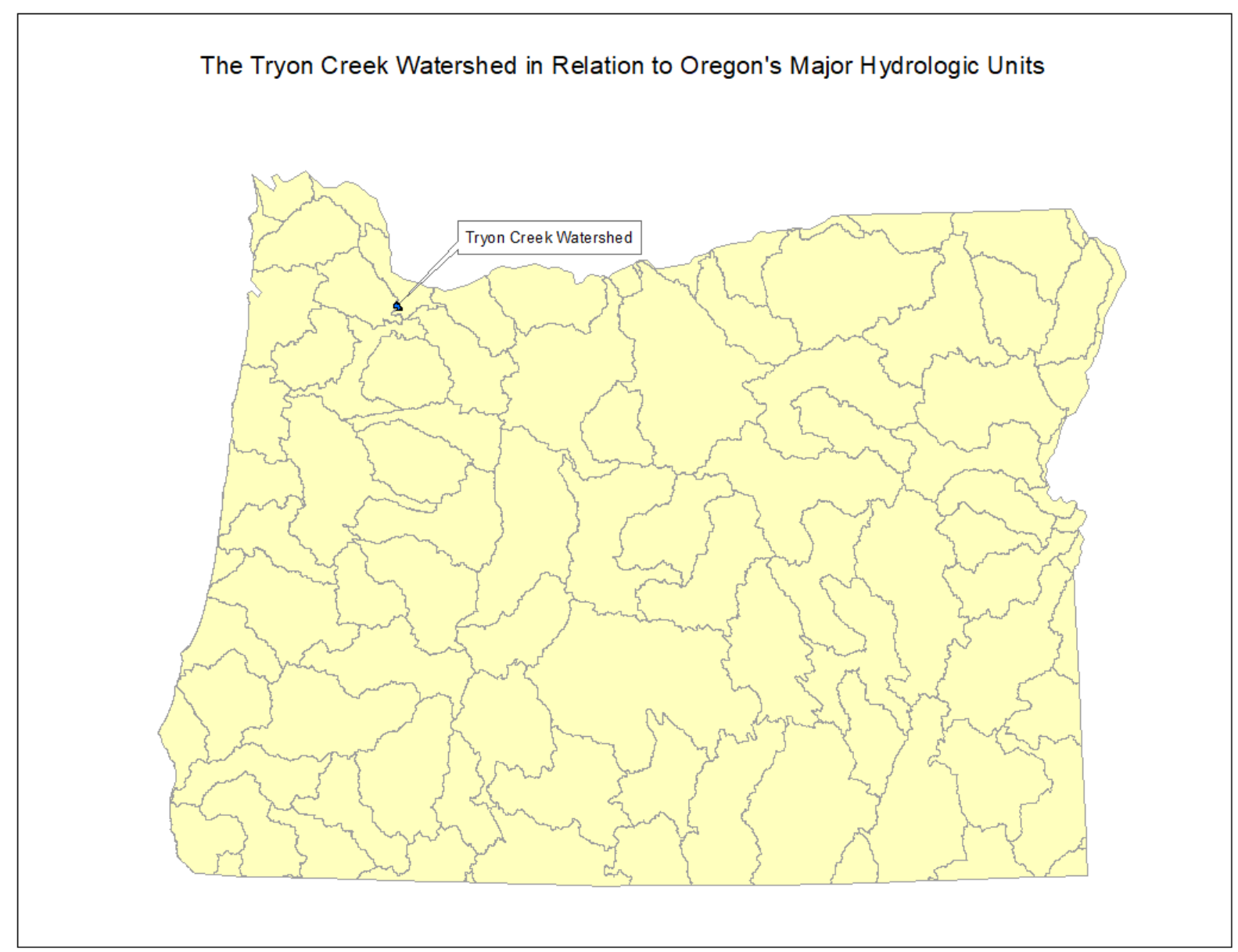

Figure 1.1: Map of Oregon showing the Tryon Creek Watershed in relation to other hydrologic units (Source: Oregon Watershed Enhancement Board).

For the purposes of this work, a watershed can be described as the area of land with connected ground and surface waterways within which all precipitation and groundwater drain down sloped surfaces to a common point. Watershed boundaries are determined by the landscape and are often manipulated by human development and use of the land (Watershed Professionals Network, 1999). Watersheds are palmate-shaped with vein-like streamlines that converge along the primary stream segment that increases in size and volume downstream. Additionally, subwatersheds are often determined for the application of management and habitat restoration that is more efficiently performed on a smaller scale.

There are multiple goals for the completion of this watershed assessment: first, this assessment will compile all existing materials regarding past and current research projects within Tryon Creek. Second, this assessment of Tryon Creek will identify data gaps that can be filled by the TCWC or partnering agencies. Finally, this assessment will examine the health of the watershed as a whole as well as target locations for restoration and protection priorities. 


\section{Watershed Issues}

The goal of identifying and assessing issues of concern for the watershed is to develop a prioritization schedule of stewardship efforts. A common issue for urban streams, such as Tryon Creek, is the occurrence of piped stream segments and influence of nearby development. Urban streams in the Pacific Northwest face challenges that impair the overall health of the watershed and its ability to support wildlife. The native plants and animals of the watershed, especially salmonid species, are the focus of many restoration and protection efforts of the past century due to their protected status. All tributaries of the Lower Willamette Basin without natural barriers, including Tryon Creek, were once abundant with anadromous fish including cutthroat trout, steelhead, Coho salmon, Chinook salmon, and Pacific lamprey (City of Portland, 2005) that are now either not present or less common within the creek due to a variety of factors, including migration barriers, degraded habitat, and poor water quality. Also related to habitat degradation is the development within the riparian zones causing decreased native plant species and increased impervious surfaces as well as invasive plant and animal species. The increased impervious surfaces and steep slopes of the watershed also contribute to dispersion of fine sediments, pollutants, and warm waters into the stream channel and consequently affect fish and macroinvertebrate habitat. Channeling the stream through pipes and culverts also adds issues including alteration of water flow, fish barriers, and sediment deposition. Impaired water quality parameters for Tryon Creek include bio-criteria, dissolved oxygen, and temperature.

The Tryon Creek watershed assessment will address these issues by providing a resource of knowledge to scientists, land managers, and the rest of the community. This resource can be used when making decisions to restore habitat or develop within the watershed. Learning about the effects of past watershed projects illuminates potential outcomes of current projects. The watershed assessment will also be a tool to prioritize work to be conducted within the watershed by the Tryon Creek Watershed Council and its partners. The focus of the included literature are the current issues and activities within the watershed. 


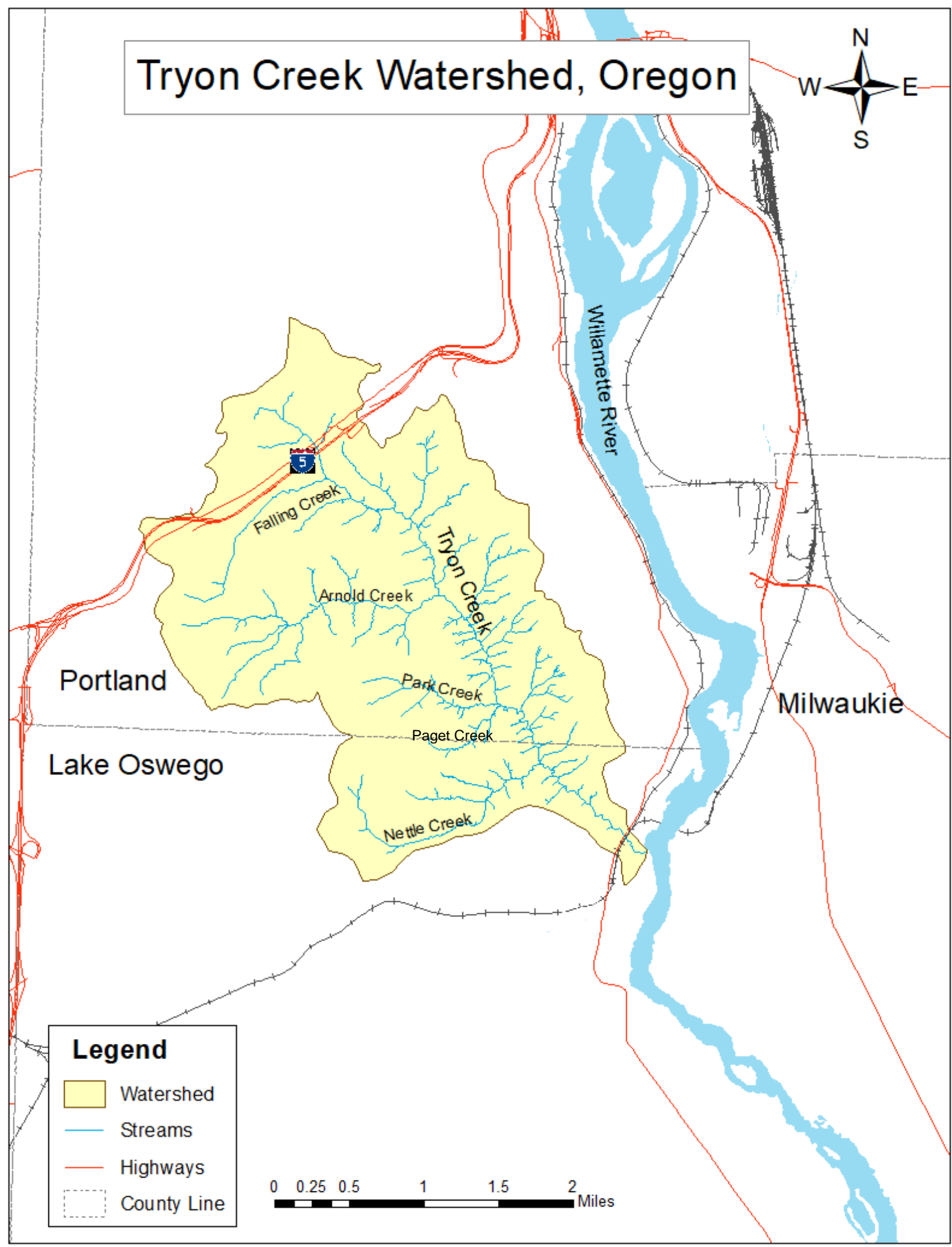

Figure 1.2. The location of the Tryon Creek watershed in Oregon (Sources: Oregon Department of Forestry, Tryon Creek Watershed Council, Oregon Department of Transportation, \& Oregon Department of Land Conservation and Development). 


\section{The Watershed in Oregon}

Watershed is one of many terms used to describe drainage areas in a variety of sizes. The boundary of the watershed was defined based on the USGS Hydrologic Unit Codes (HUC) boundary. Elevation contours are used to model the flow of water from every point within a watershed. The watershed is bounded to the east by the Palatine Hills, to the north by Portland's West Hills, and to the southwest by Mt. Sylvania (Natural Resource Management Group, 2002).

The area of land included in the Tryon Creek watershed is relatively small and contains the main stem of the stream and all of the surface water tributaries, as well as some of the unseen groundwater or piped tributaries. The notable tributaries of Tryon Creek that will be discussed within this assessment are Falling Creek (0.53 sq. mi.), Arnold Creek (1.21 sq. mi.), Park Creek (o.6o sq. mi.), and Nettle Creek (o.91 sq. mi.) (Figure 1.2). The mainstem of Tryon Creek conveys most of the water throughout the year while the tributaries have drainage areas of about $\mathbf{1} / \mathbf{2}$ that (Table 1.1). The boundary of the watershed was refined from the USGS Hydrologic Unit Codes (HUC) boundary. Elevation contours are used to model the flow of water from every point within a watershed. The watershed is bounded to the east by the Palatine Hills, to the north by Portland's West Hills, and to the southwest by Mt. Sylvania (Natural Resource Management Group, 2002).

Table 1.1: Stream reaches of the Tryon Creek watershed in Oregon (Source: Natural Resource Management Group).

\begin{tabular}{|l|l|l|l|l|}
\hline No. & Sub-watershed & Drainage Area (sq. mi.) & Min. Elevation (ft.) & Max. Elevation (ft.) \\
\hline o & Tryon Creek & 6.76 & 8 & 973 \\
\hline 1 & Falling Creek & 0.53 & 361 & 686 \\
\hline 2 & Arnold Creek & 1.21 & 169 & 973 \\
\hline 3 & Park Creek & 0.60 & 141 & 566 \\
\hline 4 & Nettle Creek & 0.91 & 107 & 561 \\
\hline
\end{tabular}

The Tryon Creek watershed is approximately 4,200 acres in size with 3,300 acres in Southwest Portland in Multnomah County and 900 acres in Lake Oswego in Clackamas County (Figure 1.2). The low gradient stream is surrounded by steep hillslopes (City of Portland, 2005). Approximately $20 \%$ of the land is protected within public and other park and open spaces, while the remaining is mostly developed land. Tryon Creek is about 7 miles long. The flow of the perennial mainstem of the creek originates in the Tualatin Hills to the west of Portland, continues southeast from the Multnomah Village area, through Tryon Creek State Natural Area, towards the Highway 43 crossing in Lake Oswego, and ending at the confluence with the Willamette River.

Tryon Creek is part of the Lower Willamette River sub-basin, which runs through the major metropolitan city of Portland, Oregon. After its passage through Portland, the Willamette River meets the Columbia River, flowing west to the Pacific Ocean. Every year, mature salmon return to their birthplaces within the Columbia River and its tributaries to spawn and lay eggs of their own (Oregon Parks and Recreation Department, 2017). This migration holds great natural and cultural importance.

The Willamette River is iconic for the development of the state of Oregon, as the northsouth Interstate 5 that connects many of the large cities runs parallel to the river. The Willamette River is also an important landscape for humans and wildlife- it is host to recreation and industrial development and a large part of the north-south migratory bird corridor (Oregon Parks and Recreation Department, 2017). Although less bountiful than in the past, the river is also a site for anadromous fish travel and other wildlife habitat. 


\section{Land Use and Ownership}

The major land uses present within the Tryon Creek watershed are residential, urban, and recreation. More than half of the Tryon Creek watershed is developed with single family homes (Houck \& Cody, 2011). With infrastructure comes the need for roads, and it was reported in 2002 that road density of the watershed is greater than 3 miles of road per square mile (Klatte \& Ellis, 2002). In general, increased impervious surfaces such as roads and buildings make flooding events more extreme, consequently altering the stream hydrology and disturbing stream habitat (Silver et al., 2017). Contaminants from automobiles, industry, and other sources enter the waterway through runoff and can harm plants and wildlife. Additionally, roads that cross the stream are built with culverts that limit passage for sensitive anadromous fish species and other aquatic organisms. This leads to an increased proportion of urban fish populations found with eroded fins, lesions, and tumors (Silver et al., 2017). Overall, the disturbances associated with a high level of development has the potential to adversely affect watershed health of Tryon Creek.

Historically, impactful land use of the watershed began after Socrates Tryon Jr. sold his inherited land to Oregon Iron Works, and the company subsequently cut and burned many western red cedars and Douglas fir for charcoal. The major logging concluded in 1961, yet the effects are still evident throughout the riparian forest. Within the next ten years, land acquisition for the Tryon Creek State Natural Area largely motivated by citizen advocacy began (Oregon Parks and Recreation Department, n.d.). With the goal to provide a public resource for education that reflected the Willamette Valley ecosystem, land was acquired between 1971 and 1988 from public and private sources and later named for the settler, Dr. Socrates Hotchkiss Tryon. Like other urban watersheds, development and increased impervious surfaces is highly impactful for Tryon Creek. With nearly a quarter of the watershed being paved, there is an increased frequency of flooding associated with rainy weather and hydromodification of the natural stream flow (Houck \& Cody, 2011). Most of the development within the watershed occurred before the implementation of stormwater management requirements of the last decade, meaning that most of the stormwater flows directly into the creek without detainment or treatment (City of Portland, 2009). Further, nearly $75 \%$ of the watershed is single-family or multi-family residential zones, which often drain stormwater directly toward the stream (City of Portland, 2012). Another effect of development is the need for culverts that contain the stream where the road crosses over. The culvert under Highway 43 in Lake Oswego for example, was built in 1920, was retrofitted with a baffle system in 2008, and a replacement has been authorized in federal legislation and now await appropriation.

The two cities in which Tryon Creek is located, Portland and Lake Oswego, work together alongside the watershed council to manage and protect the creek. The city of Lake Oswego grew in the mid-1850s as a hub of iron extraction and production with the construction of the first iron furnace on the Pacific Coast in 1867 (Kuo \& Campbell-Sack, 2013). By the late 180os, the industrial town, given the nickname the "Pittsburg of the West," had developed the First Addition neighborhood with the intention to attract residential use and continued to grow and change to a suburban environment (Borthwich, 1891).

The city of Portland was established as the prominent marketplace by John Herard Couch when he dropped anchor in 1845 and claimed it to be the furthest point that his ship can get into the mouth of the Columbia River (Katauskas, 2009). Multnomah Village, the neighborhood of Portland that contains the headwaters of Tryon Creek, was named for the Oregon Electric Railroad's Multnomah Station. The word Multnomah was originally adopted from the Chinook language. In 1907, construction began on the railroad line that operated along the Willamette Valley toward Salem (Hamilton, 2007). At that time, Multnomah was a suburban neighborhood with scattered 
dairy farms. This railway provided access for suburban communities to travel to the city of Portland for civic celebrations, cultural events, and the first Rose Festival in 1907.

The City of Portland Bureau of Environmental Services and the City of Lake Oswego are two of the partner agencies that work with the Tryon Creek Watershed Council (TCWC) to manage and protect the creek. Approximately 2/3 of Lake Oswego stormwater drains toward Tryon Creek (Callison, 2003). At different scales, each of these cities contain an urban center surrounded by outwardly increasingly dispersed suburban and forested communities. As the urban centers continue to spread, there is great pressure on landowners of the watershed to develop, and only recently has there been a focus on mindfulness of the health of the watershed (Callison, 2003). The Urban Growth Boundary of the Portland metropolitan region leads to division of land within the boundary into smaller portions and development on sites that may otherwise be deemed unbuildable or even ecologically risky. The ownership distribution within the watershed is a majority private or non-industrial (Table 1.3). This can be separated further into the categories of commercial, industrial, and mixed commercial and residential, which figure 1.3 reveals to be almost all of the watershed with a remaining large number of parks and open spaces and a few instances of public and industrial land ownership.

Table 1.3: Ownership within the watershed in percent of total land area (Source: Oregon Department of Land Conservation and Development).

\begin{tabular}{|l|l|}
\hline \multicolumn{1}{|c|}{ Ownership Class } & Percent of Watershed \\
\hline Commercial & $2.5 \%$ \\
\hline Residential & $71 \%$ \\
\hline Mixed Commercial \& Residential & $7.5 \%$ \\
\hline Industrial & $1 \%$ \\
\hline Public & $1.5 \%$ \\
\hline Parks \& Open Spaces & $16.5 \%$ \\
\hline
\end{tabular}




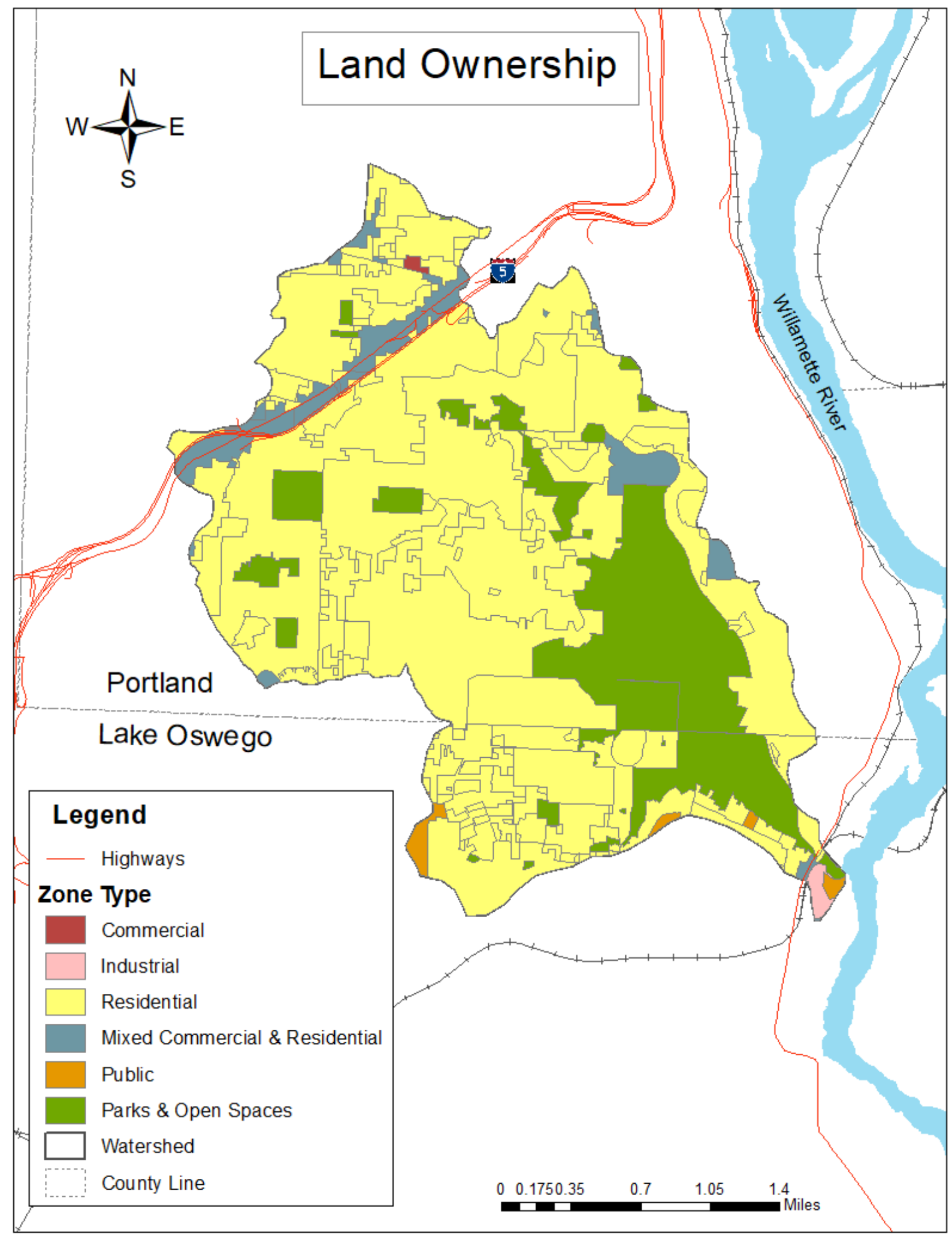

Figure 1.3: Land ownership classes within the watershed (Sources: Oregon Department of Forestry, Tryon Creek Watershed Council, Oregon Department of Transportation, \& Oregon Department of Land Conservation and Development). 


\section{Ecoregions and Vegetation}

Ecoregions are areas of land with boundaries based on biotic and abiotic phenomena, such as geology, physiography, vegetation, climate, soils, land use, wildlife, and hydrology. The ecosystem type within an ecoregion is reflected in the geology, flora and fauna, landscape characteristics, and the processes of watersheds within. The purpose of distinguishing ecoregions is to provide research, assessment, management, and monitoring of ecosystems with a spatial reference (Pater et al., n.d.). This watershed assessment discusses levels III and IV of ecoregions based on the division of the US EPA. For context of scale, the United States contains 98 regions at level III.

On the level III distinction, the Tryon Creek watershed is within the Willamette Valley ecoregion (Figure 1.4). The level IV ecoregions that are within and near the watershed are the Portland/Vancouver Basin, Prairie Terraces, and the Valley Foothills, all of which are part of the Willamette Valley. The Willamette Valley ecoregion has been described as a trough between the Coast Range to the west and the Cascades to the east (Pan, et al., 2001). Mild, wet winters and warm, dry summers characterize the Willamette Valley ecosystem with elevations that range from sealevel to about 400 feet (OPRD, 2017). With the large metropolitan areas and expansive fertile lands centered on different segments of the Willamette Valley, most of Oregon's population and agriculture are in this ecoregion. Streamflow within the Willamette Valley ecoregion is coordinated with precipitation, which occurs primarily $(\sim 75 \%)$ between the months of October and March. The pre-settlement landscape of the Willamette valley was characterized by rolling prairies, forests of deciduous and coniferous trees, and wide wetlands.

The Portland/Vancouver Basin ecoregion of the Willamette Valley is composed of many waterways with characteristic undulating terraces, floodplains, and oxbows. Today, this ecoregion is covered with urban and suburban development, and it has other anthropogenic uses such as pastures and nurseries. The Prairie Terraces ecoregion of the Willamette Valley contains characteristically low-gradient and sinuous streams and rivers. Prairie and oak woodlands maintained by burning once dominated the fluvial terraces, while Oregon ash and Douglas fir were common in wetter areas. Today, large fields of grass seed and grain crops are a common sight within this ecoregion. The final ecoregion of the Willamette Valley discussed here is the Valleys Foothills, which is characteristic of the transition zone between the three level III ecoregions of the area Willamette Valley, Cascades, and Coast Range. Originally dominant, the Oregon white oak have since been replaced with rural residential development, woodland, pastureland, vineyards, tree farms, and orchards.

There are few records of land use and habitat type before the Tryon family settled in the watershed, yet it is known that Clackamas Chinook, the Willamette Tumwater, the WascoWishram, the Watlata, the Multnomah, the Tualatin Kalapuya, the Cayuse, and the Molalla people have lived in throughout the Willamette Valley for thousands of years. The open grassland and oak habitats of the region and the accompanying native birds and wildlife depended on regularly set fires that likely also improved conditions for hunting, gathering, and travel (OPRD, 2017). Along waterways such as the Willamette River and Tryon Creek, riparian forests with expansive floodplains provided habitat for wildlife such as anadromous fish and migratory birds that flew the major-north south migratory Pacific flyway across America. With the introduction of large-scale agriculture, hydropower, and urban development and removal of controlled burning and floodplain zones starting in the mid-18oos, the area transitioned to include more coniferous forests than historically present. 


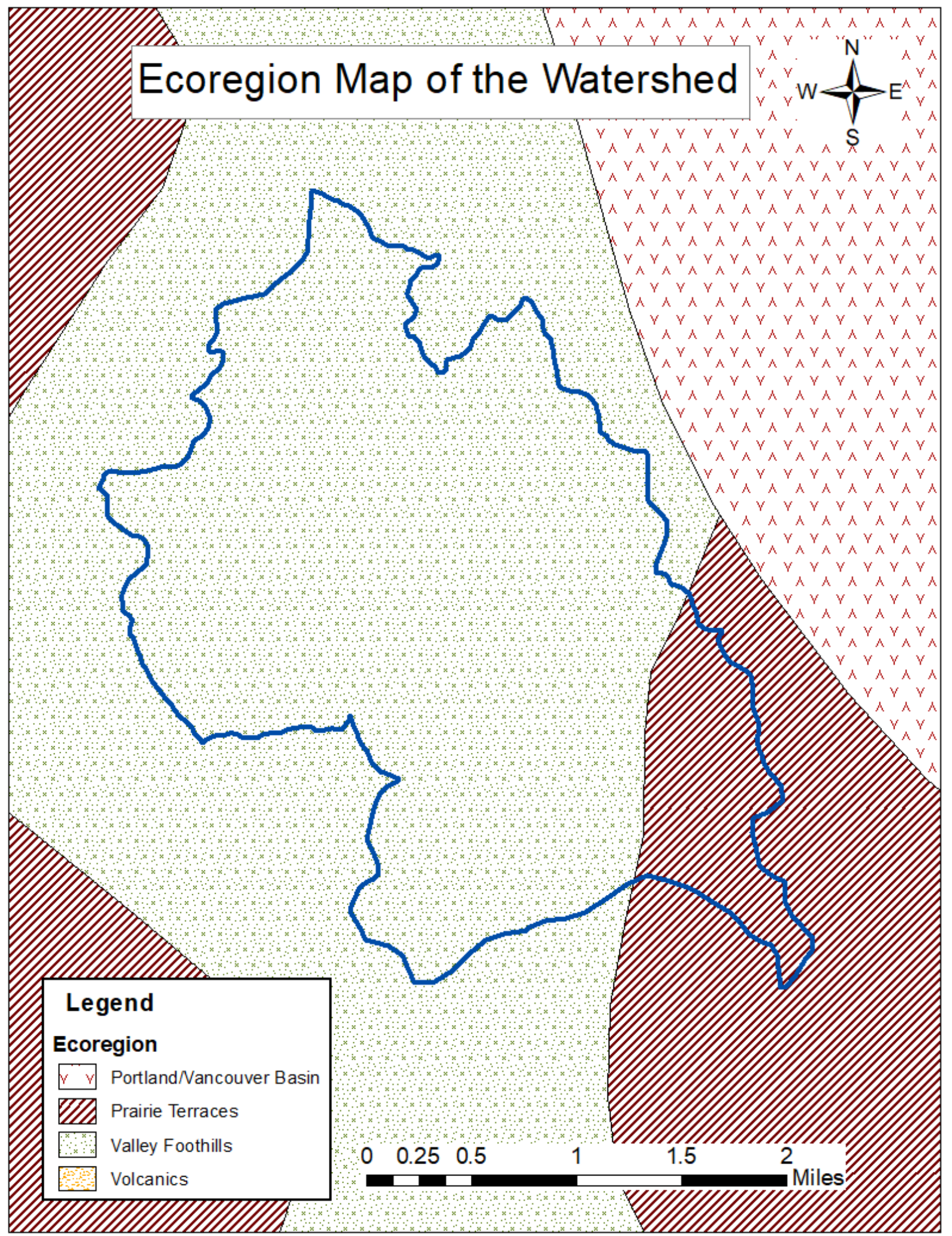

Figure 1.4: Level IV ecoregions surrounding the watershed (Sources: Geospatial Enterprise Office, Tryon Creek Watershed Council). 


\section{Geology and Soils}

Tectonic plate activity has contributed significantly to the character of this region. Converging continental and oceanic plates have developed the Cascade Mountain range, which is located to the west of the Tryon Creek watershed (Orr \& Orr, 2002). Volcanic flows, which stopped about 9 million years ago, occurred in and around the watershed. The Boring flows and Mt. Sylvania have shaped the local ecosystem through biota and topography. The erosion and sediment deposition of millions of years of geologic events have contributed to the fertile soil characteristics of the Willamette Valley. The Willamette Valley is a large alluvial plain with widths averaging 20 to 40 miles across and elevation range of o to $400 \mathrm{ft}$. above sea level (Orr \& Orr, 2002).

Many of the geological features of the area are credited to the development of the basaltic coastal range during the Eocene period. During this time, the North American tectonic plate met "an extensive line of submarine volcanoes and seamounts," resulting in the development of the basaltic coastal range of the west coast (Bishop, 2003). About 35 to 55 million years ago, The Basalt of Waverly Heights, thought to have originally been an island on the oceanic plate, became the base of the upper part of Tryon Creek State Natural Area with material consisting of basalt and undifferentiated sedimentary rocks exposed in a few locations (Friends of Tryon Creek, 1994) (Figure 1.5). A set of impactful basaltic flows from the Miocene Epoch, the Columbia River Basalt Group (CRBG), originated at the Idaho, Washington, and Oregon borders. The CRBG subsequently covered most of northern Oregon and southwest Washington between 14 and 17 million years ago, flowing around the Basalt of Waverly Heights (City of Portland, 2009). Evidence of this flow can still be seen in raised localized channel slopes, exposed basalt adjacent to Tryon Creek within the upper channel network and throughout the lower portion of Tryon Creek State Natural Area (MacDonald, 2015). The small Boring Lava flows affected parts of the watershed, including West Portland and Mt. Sylvania regions of the Tryon Creek watershed about 2 million years ago.

One of the most impactful geological events in this area were the Missoula Floods, which deposited fine-grain sediments throughout the watershed between 13,000 and 15,000 years ago (Herrera Environmental Consultants, 2009). Near the end of the last ice age, the glacial edges of Lake Missoula in northern Idaho and western Montana began to melt, filling the lake with more water. As this ice melted, the ice edge of the lake along the Columbia River would begin to float, allowing for a rush of water to flow across eastern Washington and down the Columbia River towards the Willamette River and the Pacific Ocean. It was estimated that this happened 40-100 times leaving parts of Portland under 200 feet of water and Tryon Creek under an estimated 400 feet of water (MacDonald, 2015). Cycles of flooding and dry seasons would distribute the sediments throughout the region. Alluvium deposited during and after the Missoula floods can still be found at the mouth of Tryon Creek. 


\section{Geology Map of the Watershed}
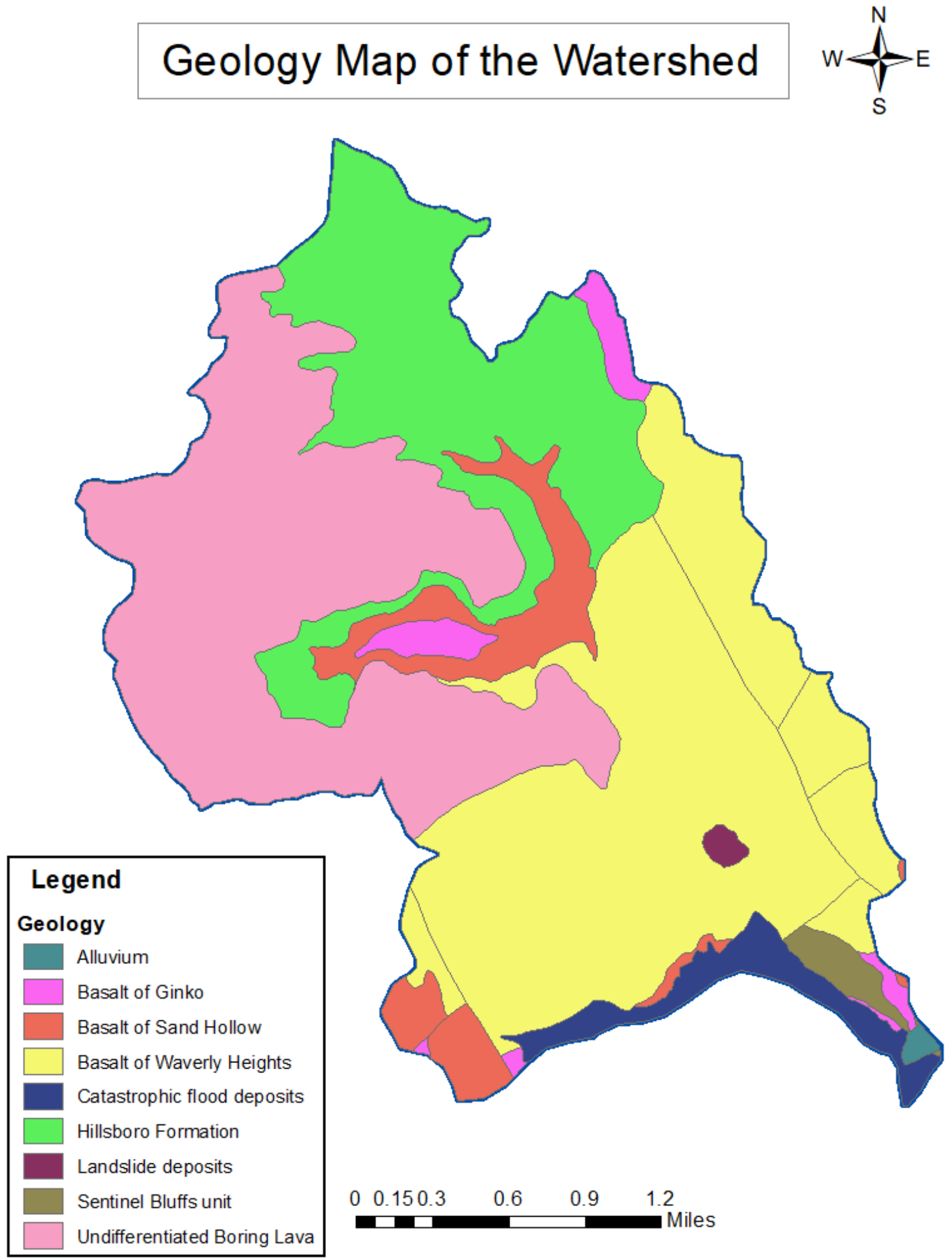

Figure 1.5: Geologic map of the watershed (Sources: Oregon Geologic Data Compilation, Tryon Creek Watershed Council). 
The soils that overlay the volcanic rocks were deposited in four distinct episodes. The oldest was deposited between the time period of the CRBG and the Boring volcano eruption and is composed of small patches of Cascade sediments (City of Lake Oswego, 2015). The next was coarser sediments from the Cascades and upper Willamette Valley deposited in the Portland basin around the same time as the eruptions from the Boring Volcanoes. The largest sedimentary deposits were from the Missoula floods that flowed down the Columbia and Willamette River Basins many times. Finally, a small patch of post-Missoula alluvium is deposited on the Willamette River floodplain northward from the mouth of Tryon Creek.

The soils in the Tryon Creek watershed are in the Cascade series, characterized by soils that are mostly silt loam with aluminum-rich volcanic ash (NRCS, n.d.). Within the watershed, almost all of the soils are silt loams or silty clay loams, which are generally characterized as somewhat poorly to moderately drained soils (Figure 1.6). Additionally, the soils tend to be mostly wet with up to a foot of dry soil for less than 2 months during the summer ( $G$ \& G, 1999). Runoff on these soil types ranges from slow to rapid; heavily influenced by slope. With approximately 6o to 75 percent of the slopes in the watershed exceeding a 30\% grade, the watershed experiences frequent landslides and erosion events (City of Portland, 2009). Other soil types reported within the watershed with less detail are Delena silt loam, Olympic silt loam, Amity silt loam, and Powell silt loam (Williams \& Coulton, 1997). The increase of impervious surfaces and development on hilly terrain puts pressure on the already unstable ground, leading to susceptibility to landslides and soil erosion (City of Lake Oswego, 2013). 


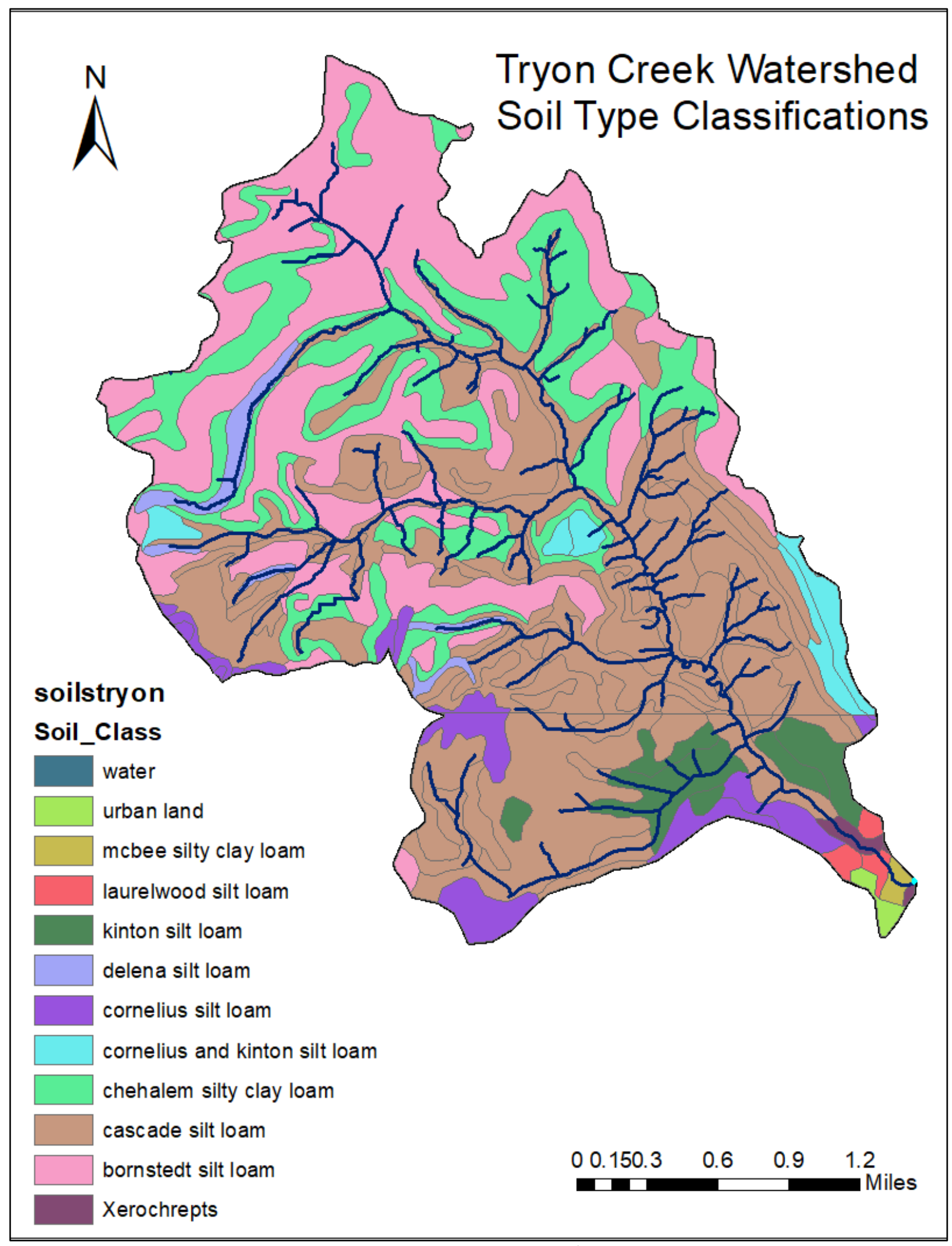

Figure 1.6: Map of soil types throughout the watershed (Sources: Natural Resource Conservation Service (NRCS) soils mapping). 


\section{References}

Bishop, E. (2003). In search of ancient Oregon: A geological and natural history. Portland, OR: Timber Press.

Borthwick, B., et al. (1891). Advertisement for First Addition Lots. Lake Oswego Preservation Society.

Callison, E. (2003). Watershed Issues: Land Use and Zoning, Riparian Protection, Municipal Regulatory Permits, Water Quality. West Multnomah Soil and Water Conservation District.

City of Lake Oswego (2015). Hydromodification Assessment.

City of Lake Oswego (2013). Comprehensive Plan Volume I.

City of Portland, Bureau of Environmental Services (2009). Tryon Creek Confluence Habitat Enhancement Design Report.

City of Portland, Bureau of Environmental Services (2005). Fanno and Tryon Creeks Watershed Management Plan.

City of Portland, Bureau of Environmental Services (2005). Framework for Integrated Management of Watershed Health.

Friends of Tryon Creek (1994). A Forest in the City: Your Guide to Tryon Creek State Park. Friends of Tryon Creek State Park.

G., A. \& G., G. (1999) Established Series. National Cooperative Soil Survey, Oregon.

Geospatial Enterprise Office (n.d.). Oregon Ecoregions. Oregon Spatial Data Library

Hamilton, N. (2007). Images of America: Portland's Multnomah Village. Arcadia Publishing: USA.

Herrera Environmental Consultants (2009). Tryon Creek Confluence Habitat Enhancement Design Report. City of Portland Bureau of Environmental Services.

Houck, M., Cody, M., \& Audubon Society of Portland. (2011). Wild in the City: Exploring the intertwine, the Portland-Vancouver region's network of parks, trails, and natural areas (2nd edition). Corvallis: Portland, Oregon: Oregon State University Press; Audubon Society of Portland

Katauskas, T. (2009). Portland Yesterday and Today. West Side Publishing, Lincolnwood, Illinois.

Klatte, B. \& Ellis, R. (2002). Tryon Creek Environmental Baseline Conditions and Limiting Factors Analysis for Anadromous Salmonids. West Multnomah Soil and Water Conservation District.

Kuo, S. \& Campbell-Sack, C. (2013). Oswego Iron Heritage Trail. City of Lake Oswego.

Lake Oswego Preservation Society (2017). Iron Industry History. Lake Oswego Preservation Society History Center \& Museum.

MacDonald, A. 2015. Hydromodification Assessment. City of Lake Oswego.

Natural Resource Conservation Service (n.d.). Web Soil Survey. United States Department of Agriculture.

Natural Resource Management Group (2002). Tryon Creek Watershed Hydrogeologic Assessment. West Multnomah Soil and Water Conservation District.

Oregon Department of Forestry (2007). Statewide Streams.

Oregon Department of Land Conservation and Development (2017). Oregon Zoning - 2017. Oregon Spatial Data Library.

Oregon Department of Transportation (2018). Oregon City Limits - 2018. Oregon Spatial Data Library.

Oregon Department of Transportation (2017). Oregon Highway Network - 2017. Oregon Spatial Data Library.

Oregon Department of Transportation (2017). Oregon Transportation Network - 2017. Oregon Spatial Data Library. 
Oregon Parks and Recreation Department (2017). Natural Resource Assessment and Strategic Action Plan- Willamette Basin.

Oregon Parks and Recreation Department (n.d.). Tryon Creek State Natural Area. Park History.

Oregon Watershed Enhancement Board (2016). Oregon Watershed Councils - 2014. Oregon Spatial Data Library.

Orr, W. \& Orr, E. (2002). Geology of the Pacific Northwest Second Edition. Waveland Press, Inc. Long Grove, Illinois.

Oswego Heritage Council (2018). Oswego Heritage Museum.

Pan, Y., et al. (2001). Bioassessment of Urban Streams (Johnson Creek and Tryon Creek). Portland State University Environmental Sciences and Resources.

Silver, B., et al. (2017). An Urban Stream Can Support A Healthy Population of Coastal Cutthroat Trout.

Tryon Creek Watershed Council (2012). Tryon Creek Watershed Boundary. Data Basin.

United States Census Bureau (2018). Annual Estimates of the Resident Population: April 1, 2010 to July 1, 2017. American Fact Finder.

Watershed Professionals Network (1999). Oregon Watershed Assessment Manual. Governor's Watershed Enhancement Board. Salem, Oregon.

Williams, P. \& Coulton, K. (1997). Phase 1 Data Review of Hydrologic and Geomorphic Conditions in the Upper Tryon Creek Watershed, 1997. Prepared for West Multnomah Soil and Water Conservation District. 


\section{HISTORICAL CONDITIONS ASSESSMENT}

\section{Introduction}

This section explores literature focused on the historical conditions of Tryon Creek and how it has been shaped into the urban watershed that it is today. To fully understand what a watershed needs as far as restoration and protection, we must first study its historical connections to its inhabitants. Human lifestyles within the region have influenced the watershed of Tryon Creek for many years and continue to do so in increasing amounts. This section is focused on recorded history of humans and how they have utilized the watershed and its resources.

\section{Methodology}

Materials for this section were found through literature searches using the Portland State University library catalog, Google Scholar, the Lake Oswego Public Library, the Oswego Heritage Council, and the Lake Oswego Preservation Society. Members of the Tryon Creek Watershed Council and partnering agencies also provided literature and directional guidance for these searches. Interviews with local residents also contributed to the compilation of a timeline and historical narrative. The purpose of this section is to set the stage for the discussion of the current conditions within the watershed. For that reason, many of these topics will be revisited with more detail in later sections. For example, historical fish populations will be mentioned here, and the topic of fish and fish populations will be further expanded later within the watershed assessment.

\section{Timeline}

A timeline provides a listed record of impactful events within the Tryon Creek watershed. Many of these events have contributed to the present state of the watershed and its resources. Note that most of these events are discussed in further detail throughout the historical conditions narrative.

Pre-settlement - The communities who have inhabited the Willamette Valley for tens of thousands of years include the Clackamas Chinook, the Willamette Tumwater, the Wasco-Wishram, the Watlata, the Multnomah, the Tualatin Kalapuya, the Cayuse, the Molalla, and other tribes and bands native to the Columbia and Willamette River Basins.

\section{- Euro/American Settlement -}

1850 - Socrates Hotchkiss Tryon came to Oregon as a pioneer and developed a homestead on the 650 acres of land, which he acquired through the Donation Land Claim Act, within the Tryon Creek watershed.

1855 - Socrates Tryon completed construction of a sawmill, converted forestland to farm, and built a house near what is now known as Stampher Road. Within this same year, Socrates Tryon died, and management of his land was conducted by his wife, Frances Tryon.

1867 - The Oregon Iron Company completed construction of the first iron furnace on the shore of the Willamette River, south of Tryon Creek.

1867-1885 - Charcoal pits were constructed to convert the fallen trees of the forest areas spanning from Tryon Creek to West Linn to charcoal to use for iron smelting.

1869 - Frances Tryon turned over her land to her children, Socrates Jr. and Sallie. 
1874 - A large tract of the Tryon family land was sold to Oregon Iron Company for $\$ 7,000$, or $\$ 10.85$ per acre. Logging of the land began soon after.

- Urban Development -

1887 - A narrow-gauge rail line connecting Lake Oswego to Elk Rock Island, which is about a mile downstream the Willamette River from the Tryon Creek confluence to deliver people and goods to steamships was constructed over Tryon Creek near the current Hwy 43.

1888 - Plans for the First Addition neighborhood of Lake Oswego, which originally housed many Oregon Iron and Steel Company workers, began just a quarter mile away from the second iron furnace.

1894 - Iron competition from the east forced the Oregon Iron Company to close operations of iron extraction, logging, and smelting in Lake Oswego.

1900 - An impactful forest fire burned through the upper canyon of what is now known as Tryon Creek State Natural Area.

1900- Construction of rail services via the Southern Pacific Railroad and the West Portland Motor Line trolley began.

1907 - The Oregon Electric Railroad was extended down from Portland through Multnomah Village to Salem.

1912-1915 - The Boones Ferry Wood and Tie Company set up a logging camp and yard near the present-day Alfred Street.

1920 - The highway 43 culvert was constructed about $1 / 4$ mile up from the confluence with the Willamette River.

1950s - F.C. and Addie Marshall donated approximately 26 acres to the City of Portland for Marshall Park.

Early 1960 - With the expectation of development expansion, a major sewer line was constructed along the Tryon Creek.

1961 - All major logging concluded within the watershed.

1962 - The Columbus Day Storm, which stretched from northern California to southern British Columbia brought heavy rainfall and extreme eastward winds to watersheds such as Tryon Creek.

- Resource Conservation and Stewardship -

1970 - Neighbors within the watershed formed the Friends of Tryon Creek to protect the natural area from the effects of the planned large-scale residential development.

1971-1988 - Land for the Tryon Creek State Natural Area was acquired as gifts from Multnomah County, Friends of Tryon Creek, as well as private landowners.

1996 - An impactful flooding event occurred throughout the Willamette Valley and its tributaries, including Tryon Creek.

1996 - The Metro Bond Measure was used to purchase Foley-Balmer and Jensen Natural Areas, now managed through an intergovernmental agreement between Metro and Portland Parks and Recreation.

Present 


\section{Historical Narrative}

\section{Pre-Settlement}

Few records exist that detail the lives of people that lived in the Tryon Creek watershed before white settlers arrived. Yet it is known that the Kalapuya occupied the Willamette Valley as far south as the Upper Umpqua basin for thousands of years (Buan \& Lewis, 1991). The Kalapuya are described as "made up of several autonomous bands loosely related by language" (Juntunen et al., 2005). Their population was estimated to have peaked at 15,000 and then decreased to about 600 in the mid-18oos due to epidemics of malaria and pneumonia. Other tribes reported present in the region by William Clark were the Clackamas, Clowewellas, and Chinook. The dominant language dialects originated from Kalapuyan-Takelman while many also used Chinook Jargon, a dialect that originated from the vocabulary of the influential Chinook Tribe and other languages. Chinook Jargon was used by local tribes for trade conversations throughout the area. The Kalapuya lived in villages composed of familial bands within river valleys and tributaries, while camping outside of the village seasonally to gather food and supplies. It has been described that the land within the Tryon Creek watershed has historically been hospitable because of its proximity to the Willamette River and the presence of abundant native vegetation (Sheoships, 2019). Both the water system and the green forest provided unique food such as camas and salmon as well as resources to maintain a livelihood supported by the land.

The majority of the tools that have been unearthed within the watershed are those of stone because organic materials did not preserve well in the acidity of the valley soil. Stones were carved into different shapes for a variety of uses including fishing weights, hide scrapers, and projectile points (Oswego Heritage Council, 2018). One of the few wood-based tools built by many groups of western Oregon were canoes for the purpose of water transport. It is likely that in the early 180os Native inhabitants of Tryon Creek traveled in canoes or other boat styles across the Willamette River to the newly developed city center in Oregon City for trading. Oregon City was established in the 1820 os by John McLoughlin of the Hudson's Bay Company for its proximity to the Willamette Falls, which propelled the Hudson's Bay Company's lumber mill. The Willamette River also provided a way for traders to arrive in Oregon City to partake in trading of fur, which was the Hudson's Bay Company market, and other goods (Fulton, 2002). There are also records of fishing off the canoes and riverbanks through the use of spears, detachable harpoon heads, line and hook, clubs, lures and bait, and basket traps. The pre-settlement vegetation was likely dominated by latesuccessional and old-growth Douglas fir and other conifers including western red cedar, western hemlock, and grand fir (Smith \& Morrison, 2007). With varying patches in canopy cover, red alder was also more common as pioneer species in open areas.

\section{Homestead Settlement}

In 1850, the Vermont-born physician, Socrates Hotchkiss Tryon, settled his family on the land now known as the Tryon Creek State Natural Area (Friends of Tryon Creek, 1994). He and his wife brought son Socrates Jr. from California to settle here and daughter Sallie was born in 1852. Tryon gained this land through the Donation Land Claim Act, a program that attracted homestead settlement in Oregon by granting land to those that claimed it in the early 1850 . By 1855 , Tryon and his family had built a sawmill, farmed an area of land, and constructed a home on the land that was primarily covered with Douglas fir and western red cedar (Oregon Parks and Recreation Department, n.d.). The rural farmhouse stood on a flat area above the Willamette River on what is now known as Stampher Road until the 1990s. The Tryon homestead was a desired location because of its proximity to the creek and the Willamette River, yet potentially less desirable due to the steep slopes surrounding the waterways. Socrates died in 1855 , leaving his land to his wife Frances. When 
she died in 1869, she turned over their 645 acres to her children Socrates, Jr., Sallie, and Sallie's husband, A.A. Cleveland. They sold the land in 1874 to the Oregon Iron Company for $\$ 7,000$, or $\$ 10.85$ per acre. The creek and later the Tryon Creek State Natural Area were both named Tryon, the first known settler of European descent (Friends of Tryon Creek, 1994).

The Tryon family story is more accurately represented in historically records, partly because they owned land that now makes up the Tryon Creek State Natural Area. The story of the Tryon family settlement was one of the more well-documented to settle in the Tryon Creek watershed through the Donation Land Claim Act, yet there were many other landowners that left a mark on the area. For example, Multnomah Village, the location of the Tryon Creek headwaters, is a part of the land that Thomas Tice and his wife Polly claimed in 1852 after moving to Oregon from Missouri with their three children (Hamilton, 2007). This time period marks the beginning of welldocumented legacy activities, or "past land use practices that have contributed to current watershed and stream channel conditions” (Watershed Professionals Network, 1999).

\section{Forestry}

Soon after the purchase of the Tryon family land in 1874, Oregon Iron Company began logging the cedar and fir trees. This purchase would set off a short-lived, yet productive run of iron mining and smelting in the Lake Oswego area. Economic development that came with the iron industry of the area led to construction of rail lines and housing in and around the area (Fulton, 2002). Logging continued intermittently until the mid-189os to provide charcoal for the pig iron foundry in Lake Oswego. As demonstrated in figure 2.1, the trees naturally available for logging at the time were almost all coniferous and mixed. Lumber harvested by Albert Durham's company was shipped to California all the way down to parts of South America (Fulton, 2002). The current Iron Mountain Trail within Tryon Creek State Natural Area was constructed on a previous logging road from this time period. Between the years of 1867 and 1885, this road was used to deliver wood to large mounded pits where the wood was slow heated and transformed into charcoal to use in the iron smelting process (Kuo \& Campbell-Sack, 2017). A forest fire later burned through a portion of the natural area around 1900, leaving charred snags that have been observed from the northerly portion of the Maple Ridge Trail as recently as within the last 20 years (Friends of Tryon Creek, 1994).

The Boones Ferry Wood and Tie Company constructed a logging camp and yard on what is now Alfred Street and logged the area between 1912 and 1915. This lumber was used primarily for railroad ties, fence posts, and cord wood and hauled out using a corduroy road constructed with tree trunks on the east side of the creek toward the current Fourth Avenue. Equipment from this operation, including a steam donkey engine that was removed from the canyon when a sewer line was built along the creek in the early 1960 , were left or forgotten in the area as historical relics. A shorter and less documented period of logging, this time in the south part of the canyon, began in the early 1950s (Friends of Tryon Creek, 1994). The final logging practices of note was that of a 200acre tract at north end of the canyon in 1961. With the removal of much of the old-growth forest, came the introduction of deciduous and mixed conifers which are now the dominant vegetation of the forest in addition to sporadic old-growth trees (Smith \& Morrison, 2007). Today the Tryon Creek State Natural Area and surrounding neighborhoods are primarily second growth Douglas fir, western red cedar, big leaf maple, and red alder trees (Friends of Tryon Creek (1994). 


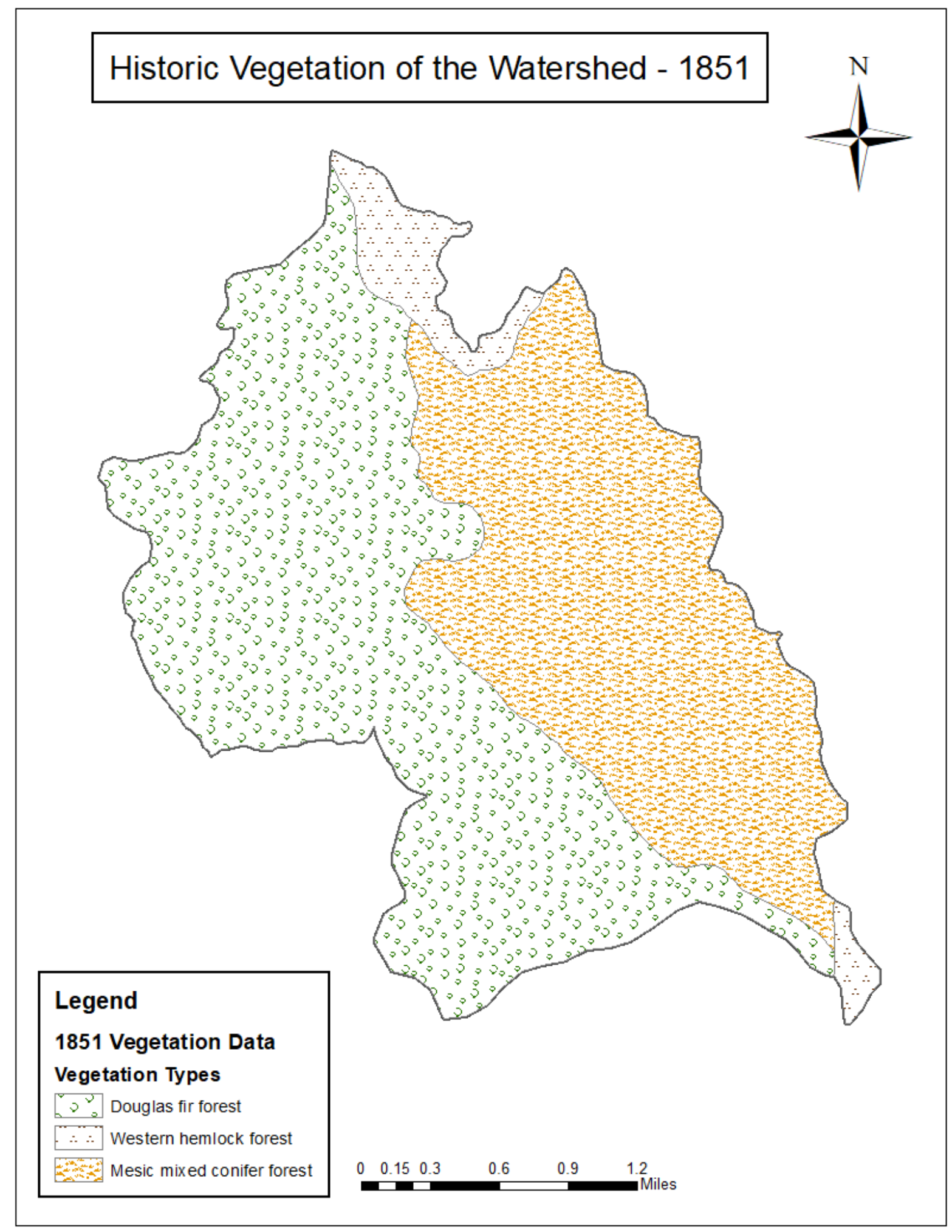

Figure 2.1: Pre-settlement vegetation of the watershed (Sources: Metro Data Resource Center, Tryon Creek Watershed Council). 


\section{Farming}

Dairy farming was common in the forested hills to the south and west of Portland. Trees were cleared and used for fencing, leaving grassland and scattered stumps for cattle to graze until the landowner had enough resources for the arduous task of clearing the stumps for development (Hamilton, 2007). Many of these dairy farms were operated by Swiss immigrants, such as Bill and Anna Raz and their ten children who all emigrated from Switzerland to Oregon throughout the 188os. The Raz Brothers Dairy underwent a series of name and ownership changes to eventually be sold to Alpenrose Dairy which is an ongoing dairy company in the area (Hamilton, 2007). There were many examples of dairy farms in Lake Oswego as well, including the A Avenue Dairy located in what is now known as the First Addition neighborhood (Oswego Heritage Council, 2018). Before the real estate campaign to draw new residents to Lake Oswego in the early 190os, the primary source of income for landowners was farming or the iron business. There are many other examples of families that farmed on land acquired through Donation Land Claim or land bought from the time of that act. Otto and Frances Kruse, originally from Germany, purchased farmland near the current Carman Drive in Lake Oswego in 1863 where they grew cabbage, cauliflower, grain, and hay. The crops, which their sons continued to farm after Otto and Frances died, were transported to Portland by wagon and later by truck (Oswego Heritage Council, 2018). At the time, cauliflower was a new crop in Oregon and the Kruse farm was even featured in a 1913 issue of the Oregonian for their innovative practices (Foster, 2009). Although this farm was not within the Tryon Creek watershed, their farming practices were well-known and indicative of others in the area.

The Woodlee Heights subdivision of the Arnold Creek area now stands on previous farmland. Specifically, the land that the Stephenson Elementary School occupies was a hop farm and still contains a small farm and cow pastures (Marantz, 2019). There are other signs of agricultural and horticultural historic activities, such as the remaining steel and glass greenhouses on Stephenson Court. One property that has been passed on through multiple generations was originally owned by the late Gordon Wilshire, a renowned miniature rose horticulturist. Today the Arnold Creek area is developed into subdivisions with a suburban design, featuring curving streets and pocket neighborhoods that exit onto Stephenson Street (Marantz, 2019).

\section{Fires}

The native Kalapuya managed the ecosystems of the Willamette Valley for hundreds of years by igniting regular fires. In addition to maintaining the natural grassland, oak savanna, and riparian forests of the region, the fires also likely improved conditions for hunting, gathering, and traveling (Oregon Parks and Recreation Department, 2017). Fire was historically used by the Kalapuya for both immediate and long-term results (Juntunen et al., 2005). In the short-term, fires were used to confine game animals for easier hunting, to clear fields of crops, and even to gather acorns from oaks that could withstand a small fire. Long-term fire use eliminated unwanted plants and encouraged healthy plant regrowth, as well as altering habitats for the preference of animals to hunt, such as removal of woody materials to improve habitat for ducks.

A more recently recorded impactful fire was one that swept through the upper canyon of land now within the Tryon Creek State Natural Area in 190o. Evidence of this fire has been observed as recently as the mid-1990s in the charred snags and stumps within that part of the forest (Friends of Tryon Creek, 1994). Today, the watershed is dense with residential and urban development, making it dangerous for managed fire practices. 


\section{Fish Populations}

Oregon state fish biologists have tracked the passage of salmon such as Coho, steelhead, and cutthroat from the Columbia River system through the Willamette Falls and into the upper portions of the Willamette River and its tributaries since as early as 1903 (City of Portland, 2005). The Multnomah Channel is a longstanding entrance into the Willamette River basin for anadromous fish such as Coho, steelhead, and cutthroat. Due to hydrologic inaccessibility in the upper Willamette River basin and the Willamette Falls, only individuals able to survive the difficult passage were believed to be the only anadromous fish able to access and populate areas in the middle and upper Willamette River basin. With improvements of the hydrologic regime and fish passage over the falls, historically absent anadromous fish including summer steelhead, Coho and fall Chinook were able to naturalize in sub-basins upstream of Willamette Falls (City of Portland, 2005). Among the anadromous species to suffer from historic operations of Willamette Basin dams are the wild spring Chinook. The Oregon State Game Commission has historically stocked Coho into the creek, yet populations have not been able to recover to numbers before the installation of the Hwy 43 culvert. Although beaver populations have not been surveyed in Tryon Creek, it is known that they are often found to co-exist with anadromous salmonid species in the Willamette Valley and throughout the rest of the Pacific Northwest (Petro, et al., 2015). American beavers (Castor canadensis) are commonly found in forests dominated by Douglas fir (Pseudotsuga menziesii), which is present throughout large parts of the Tryon Creek watershed.

\section{Floods and Storms}

Tryon Creek is prone to higher flows during storm events due to extended wet periods, steep surrounding slopes, and soil characteristics that prevent infiltration (City of Portland, 2005). Rain and snow melt cause rapid increase in water levels and flow rates, affecting hydrologic factors throughout the watershed.

Although the effects on Tryon Creek are less discussed, the Columbus Day Storm of 1962 was caused by a typhoon called "Freda," that brought winds of up to $116 \mathrm{mph}$ to downtown Portland (Katauskas, 2009). This storm that developed in the Pacific Ocean traveled toward land with the force of a Category 3 hurricane. Infrastructure, power lines, and vegetation, including trees hundreds of years old, were destroyed from Northern California to southern British Columbia. It was reported that nearly $70 \%$ of the 4,ooo homes of Lake Oswego were damaged to some degree during the windstorm (Read, 2015). It is likely that destruction to forested and developed parts of the Tryon Creek watershed also occurred.

Another well-known storm event that hit the Portland area took place in February 1996. The flood was recorded to have caused millions of dollars of damage to the region. The intensity of the flooding was a result of combination of multiple factors- heavy winter snowfall in the area, a massive storm in the western Pacific, and a La Niña pattern that pushed this storm toward Washington and Oregon instead of its usual path toward California (Jennings, 2003). The heavy rainfall continued for three days in early February and was measured at half an inch an hour in some locations. In combination with melting snow, this rain forced rivers and streams well above their winter banks, leading to mudslides and floods throughout the region. The Tryon Creek watershed experienced severe landslide, streambank and streambed damage, yet did not cause significant property damage comparable to that of other impacted areas (City of Portland, 2005). The consequential bank erosion caused a detriment to the water quality of the watershed, resulting in the 303(d) listing by the OR department of Environmental Quality (DEQ) (City of Portland, 1997). Through the regulation of dam flows along the Columbia and tributaries of the Willamette, the US Army Corps of Engineers was able to minimize damage to Portland and the Willamette Valley. The 
events of the flood encouraged environmentalists, concerned citizens, and government agencies to evaluate how human development and associated actions affect flooding patterns and intensity.

The stream gauge monitored by the United States Geologic Survey reports a more recent peak flow in early 2017 at approximately 610 cubic feet per second (CFS), which is over $50 \%$ higher than the second highest recorded peak flow of the last 20 years (United States Geologic Survey, 2019). This is a result of the rapid melting of a snowstorm that occurred throughout the Portland area in January 2017. Increased development of urban watersheds causes snowmelt and rain to run off impervious surfaces and directly into storm drains and creeks without the lag time that soil filtration provides for natural systems.

\section{Channel Modifications and Restorations}

A characteristic of Tryon Creek that has intensified is flood response to storm events, and there are many stream channel characteristics that have been altered throughout the timeline of the watershed. City of Portland (2005) notes that the lower portion of the Tryon Creek historically had a more meandering and curved path.

Prior to the development boom of the mid-19oos, the floodplain was more expansive, and the water system was responsive to storms as far as water level, but less so than today. With structures and impervious surfaces close to the creek, runoff into the creek moves at a faster rate causing the creek to flood more dramatically during storm events. Channel confinement has been recorded back to around the 1970 s and likely took place earlier than that. Historic aerial photographs and maps reveal that channel migration has been nonexistent since 1852, indicating likely control by humans for development or other purposes (City of Portland, 2009). In a natural setting, the channel is free to migrate naturally, yet it is now controlled by humans to flow in a particular path. Another factor that can cause consistency in stream location, such as the mouth of Tryon Creek, could be constant sediment deposition from fast moving waters slowed by rocks or changes in flow rate.

The upper portion of Tryon Creek has undergone a lot of channel modifications in the form of culverts, ditches, and even piping the stream. A recent restoration project to target a portion of this was conducted by the City of Portland at the headwaters. The project was located on a 2.7-acre site that was contaminated with gasoline, oil, and cleaning fluids assumedly from an auto mechanic shop that operated there in the 1940s. The site had later been developed resulting in 900 feet of the creek being piped and buried (Houck \& Cody, 2011). After the 2009 removal of contaminated materials and restoration of the headwaters, a large portion of the creek was day-lighted, and the banks were planted with native shrubs and grasses.

A location of Tryon Creek that has experienced impactful channel modification is where it crosses under highway (Hwy) 43. In 2008, multi-agency work was completed to raise the stream to "swim-in" level and re-contour the channel below, as well as replace baffles in the culvert. Although this work did not result of fish passage upstream, it was a significant effort that decreased the vertical distance between the culvert and stream. Comparison of historic maps from 1852 and 1927 display that a meander upstream from Hwy 43 may have been removed (City of Portland, 2009). A 1949 map and historic photographs also show that there was once a second channel that diverted from the main channel upstream from the Hwy 43 culvert, yet it is not conclusive if Tryon Creek was truly multi-threaded near its confluence with the Willamette River. This also indicates that the channel was shortened and steepened by the installation of the Hwy 43 culvert. Residents of Tryon Creek have noted the effects of land management, including the construction of this culvert and others throughout the last century and earlier (Hedlund, 2019). 


\section{Park Development}

In 1970, large-scale residential development continued within the watershed and many neighbors took notice that this may negatively impact the health of the watershed. The Friends of Tryon Creek was started by a group of concerned neighbors to conserve the natural resources of the creek and its surrounding forest (Houck \& Cody, 2011). Between the years 1971 and 1988, land was purchased from private landowners and acquired by gifts from Multnomah County, Friends of Tryon Creek, and other landowners (Oregon Parks and Recreation Department, n.d.). Around this time, Governor Tom McCall and the Transportation Commission Chair Glen Jackson made the decision to purchase the first urban park of the Portland area, which was officially named the Tryon Creek State Natural Area in the 1990s. Today, the park has 14 miles of trail, some of which that follow historic logging roads. The forested park provides a classroom for students young and old to connect to the natural and cultural values of the Tryon Creek watershed. Restoration and protection of the watershed currently takes place within the state natural area by Oregon State Parks employees and volunteers as well as outside of the park by the Tryon Creek Watershed Council, other agencies, and individual community members. Designating parks and restoring land throughout the watershed is a key part of people's impacts on the watershed today.

\section{Conclusions}

The history of Tryon Creek is a relatable narrative for much of Oregon with the relatively rapid transformation following the Donation Land Claim and Homestead Acts of the mid-18oos. Before this time, native populations lived for thousands of years with the land in a seemingly low impact lifestyle. Historic logging, flood management, and urban development are a few anthropogenic actions that largely shape the current conditions of the Tryon Creek watershed. Through the beginning of residential development, neighbors of Tryon Creek recognized its value and stood up for its conservation. Through the review of historical conditions, it is important to remember that they are not synonymous with restorable conditions. There are many factors that affect restoration or reestablishment of a watershed, especially one that has a deep anthropogenic history.

\section{Data Gaps}

Many records of the natural and cultural history of Oregon, and even Willamette Valley history exist, yet those of Tryon Creek are far sparser. Historical records with a focus on life within the cities of Lake Oswego and Portland were also used to learn more about human interactions with the Tryon Creek watershed. It should be noted that historical information detailing life within the watershed before the settlement of Socrates Tryon was only briefly mentioned in reports reviewed for this project. Whether that is because it is less understood due to lack of artifacts or other reasons is unclear. For this report, there is a strong focus on actions of humans that have shaped the Tryon Creek watershed to its current condition. For that reason, additional historical information about the iron industry, settlement, and development of city centers of Portland, Lake Oswego, and other local cities were not included in a high level of detail. 


\section{References}

Buan, C. \& Lewis, R. (1991). The first Oregonians: an illustrated collection of essays on traditional lifeways, federal-Indian relations, and the state's native people today. Oregon Council for the Humanities.

City of Portland, Bureau of Environmental Services (1997). Upper Tryon Creek Corridor Assessment.

City of Portland, Bureau of Environmental Services (2005). Fanno and Tryon Creeks Watershed Management Plan.

City of Portland, Bureau of Environmental Services (2009). Tryon Creek Confluence Habitat Enhancement Design Report.

Foster, L. (2009). Images of America: Lake Oswego. Arcadia Publishing, USA.

Friends of Tryon Creek (1994). A Forest in the City: Your Guide to Tryon Creek State Park. Friends of Tryon Creek State Park.

Fulton, A. (2002). Iron, Wood \& Water. An Illustrated History of Lake Oswego. Oswego Heritage Council.

Hamilton, N. (2007). Images of America: Portland's Multnomah Village. Arcadia Publishing: USA. Hedlund, W. (2019). Phone interview with William Hedlund.

Houck, M., Cody, M. J., \& Audubon Society of Portland. (2011). Wild in the city: Exploring the intertwine, the Portland-Vancouver region's network of parks, trails, and natural areas (2nd edition). Corvallis: Portland, Oregon: Oregon State University Press; Audubon Society of Portland.

Jennings, T., et al (2003). Currents of Change: A History of the Portland District, U.S. Army Corps of Engineers, 1980-200o. Portland, Ore.: U.S. Army Engineer District.

Juntunen, J., et al. (2005). The World of the Kalapuya a Native People of Western Oregon. Benton County Historical Society and Museum. Meadowlark Communications, Inc., Corvallis, Oregon.

Katauskas, T. (2009). Portland Yesterday and Today. West Side Publishing, Lincolnwood, Illinois.

Kuo, S. \& Campbell-Sack, C. (2017). Oswego Iron Heritage Trail. City of Lake Oswego.

Marantz, L. (2019). Email interview with Liz Marantz.

Metro Data Resource Center (2014). Vegetation (1851). RLIS Discovery.

O'Connor, K. (2012). February 1996 Flood with Metro Goal 5 Updates, Portland Metro Region, Oregon. US Army Corps/Metro Data Resource Center.

Oregon Parks and Recreation Department (2017). Natural Resource Assessment and Strategic Action Plan- Willamette Basin.

Oregon Parks and Recreation Department (n.d.). Tryon Creek State Natural Area. Park History.

Oswego Heritage Council (2018). Oswego Heritage Museum.

Petro, V., et al. (2015). Evaluating landowner-based beaver relocation as a tool to restore salmon habitat. Global Ecology and Conservation. Volume 3, pages 477-486.

Portland Parks and Recreation (2009). Habitat Management and Trail Plan Marshall Park Natural Areas.

Read, W. (2015). The 'Big Blow' of Columbus Day 1962. Office of the Washington State Climatologist.

Sheoships, G. (2019). Email interview with Gabe Sheoships.

Smith, H. IV \& Morrison, P. (2007). Vegetation Inventory and Mapping of Tryon Creek State Natural Area. Pacific Biodiversity Institute, Winthrop, Washington.

United States Geologic Survey (2019). USGS 14211315 Tryon Creek near Lake Oswego, OR. 


\section{CHANNEL HABITAT TYPE ASSESSMENT}

\section{Introduction}

Channel habitat types are a way to classify stream segments based on watershed runoff, landform relief, geology, and other characteristics that influence erosion and deposition processes (Paustian, et al., 1992). These characteristics further understanding of channel properties and ability to predict responses to natural and human influences. There are many systems used to classify channel habitat types of streams in all ranges of orders. This section will highlight the results from two stream classification projects from the City of Portland Bureau of Environmental Services in 1997 and 2005. Many parts of Tryon Creek can be described as steep and narrow with few instances of large woody debris or dynamic aquatic habitats (City of Portland, 2009). The research highlighted in this section will divide the creek into segments that are described with further and more unique details.

The completion of this section of the Tryon Creek Watershed Assessment compiles data from previous resources, including the 1997 Upper Tryon Creek Corridor Assessment and the 2005 Fanno and Tryon Creeks Watershed Management Plan. In 1997, the City of Portland reported that the steep slopes and relatively impervious soils of the Tryon Creek watershed make it especially vulnerable to the effects of development including increase in impervious surfaces such as roads and buildings (City of Portland, 1997). A goal of the Upper Tryon Creek Corridor Assessment was "identification of damaged or exposed infrastructure (undermined culverts or exposed sewer pipe located in the stream), areas of incised channel bed, stream bank failures, slope failures, locations of debris jams, landscaped areas, areas of potential fish habitat enhancement, and other potential stream enhancement," yet this section will focus on the attributes related to channel habitat types (City of Portland, 1997). This research focused on assessment of Tryon Creek upstream from Boones Ferry Rd. including Tryon Creek as well as the following tributaries- Falling, Arnold, Oak, and Quail Creeks. The Fanno and Tryon Creeks Watershed Management Plan of 2005 is another report completed by City of Portland Bureau of Environmental Services and the resulting report "characterizes watershed conditions, identifies watershed problems and assets, and recommends a comprehensive and strategic set of projects, programs, and activities to improve watershed health" (City of Portland, 2005).

One of the goals of this watershed assessment is to determine areas of the watershed that are in need of restoration or protection (Watershed Professionals Network, 1999). An understanding of channel habitat types present within the watershed will aid in the maintenance of present stewardship efforts and guide the focus of those efforts in the future. Application of channel habitat type classification is conducted under a few assumptions, the first of which is that surrounding geology and geomorphology impact the specific patterns of stream channels and this can be used to classify channel habitat type (Watershed Professionals Network, 1999). The second assumption is that channel habitat types respond to inputs of sediment, water, and wood in predictable manners. Finally, the third assumption is that the aquatic habitat quality is influenced by the distribution and condition of the characteristics of channel habitat types throughout the stream network.

Setting and structure of an environment both impact the shape and flow rate of a creek (Watershed Professionals Network, 1999). To better understand the influences of humans and natural events throughout the watershed, it is helpful to first study the channel habitat of Tryon Creek. Channel modification, restoration, and protection are actions that greatly effect fish habitat quality through the alteration of the channel habitat type. A goal of the Tryon Creek Watershed 
Council is to make lasting positive impacts within the watershed which means that an understanding of which efforts are more effective within each stream reach would assist in the achievement of that. Stream classification will ultimately lead to a better understanding of how land use affects stream flow and prepare for how different stream classifications will respond to stewardship efforts (Watershed Professionals Network, 1999). Understanding of classifications will lead to the best decisions for wildlife use of the watershed. Ultimately, this assessment will result in an overlook of which stream segments are in need of restoration that will work with the channel habitat type for the goals of the watershed council.

\section{Methodology}

\section{Upper Tryon Creek Corridor Assessment}

The Upper Tryon Creek Corridor Assessment completed by the City of Portland BES described channel characteristics of the upper portion of the watershed. Field observations of instance of events including "damaged or exposed infrastructure (undermined culverts or exposed sewer pope located in the stream), areas of incised channel bed, stream bank failures, slope failures, locations of debris jams, landscaped areas, areas of potential fish habitat enhancement, and other potential stream enhancements." (City of Portland, 1997). This assessment was conducted in April 1996 (a few months after a historically high storm event inundated the Portland area) and focused on stream reaches upstream of SW Boones Ferry Rd, including Tryon Creek mainstem, Falling, Arnold, Oak, and Quail Creeks. Extent of erosion was determined based on the calculation of a 2year flow $\left(\mathrm{Q}_{2}\right)$ and 10-year flow $\left(\mathrm{Q}_{10}\right)$. Observations and photo documentation were recorded by scientists walking the length of the study site.

\section{Fanno and Tryon Creeks Watershed Management Plan Reach Descriptions}

The channel habitat types will be focused on the stream reach descriptions reported in the Fanno and Tryon Creeks Watershed Management Plan, in which the City of Portland divided Tryon Creek into stream reaches with common hydrologic, land use, or habitat features. Other factors that were considered in the determination of stream reaches were land use, gradient, tributary confluences, significant culverts and barriers, and other important habitat features. It is noted that reach breaks may also be defined by the presence of structures such as culverts that create breaks in stream connectivity and function (City of Portland, 2005). In order to provide highly detailed habitat descriptions, sub-reaches were also assigned throughout the watershed (Figure 3.1). Descriptions of each stream reach, its habitat characteristics, and river miles (distance from the Willamette River confluence) were recorded. Data collection followed the same reach designation as that of Oregon Department of Fish and Wildlife in the Aquatic Inventory Project Physical Habitat Surveys 2001. This study relies largely on observation and variables recorded through this method include date, reach, channel form, valley form, streamside vegetation, land use, stream flow, location, and additional reach notes (Moore, et al., 2019). These responses were then combined and summarized to gain an understanding of each stream reach. 


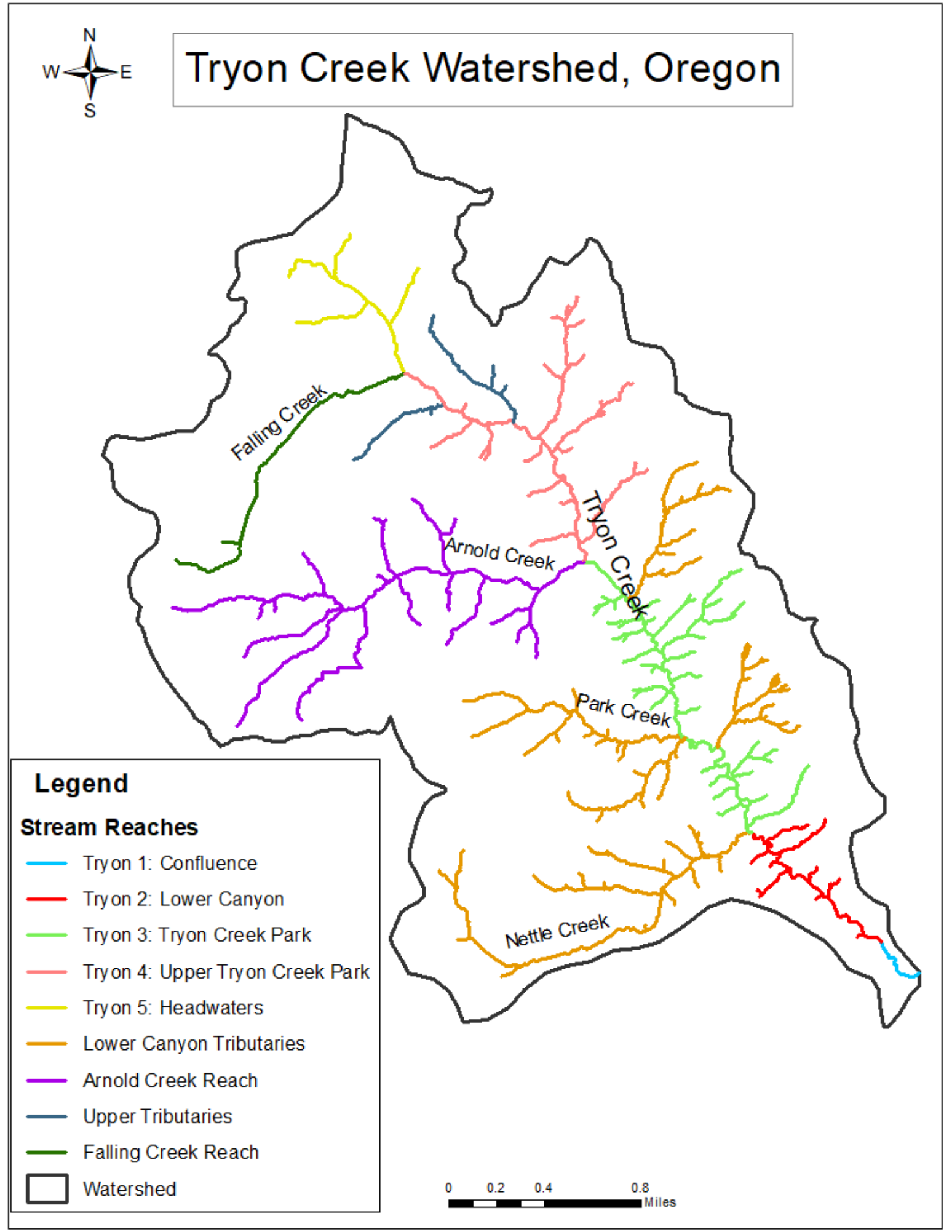

Figure 3.1: Map of the primary stream reaches described by the City of Portland (Source: City of Portland). 


\section{Results}

\section{Reach Descriptions}

In an effort to provide recommendations for improvement of channel habitat, the City of Portland documented creek corridor and riparian conditions of the Upper Tryon Creek corridor. More recently, the City of Portland assessed Fanno and Tryon Creeks together in a join watershed management plan. This report goes into detail about many aspects of each of the two watersheds and discusses them side-by-side. The following text was adapted directly from each of the documents and pasted together where appropriate to best provide an interpretation of the channel habitat conditions in and around Tryon Creek. Observations referring to right or left bank use the conventional assumption that one is facing downstream (City of Portland, 2005). The use of [brackets] denotes descriptions paraphrased from the Upper Tryon Creek Corridor Assessment (1997) based on field observations of channel conditions. The stream reaches of the two reports were not designated using the same parameters, leading to incongruous descriptions.

\section{Mainstem Tryon Creek}

Tryon 1: Confluence

Mouth of Tryon Creek (Willamette River) to the west side of HWY 43 (river mile [RM] o.o to 0.24 ; approximately 1,286 feet)

This reach includes Hwy 43 culvert at the upstream end. Stream gradient is low at 2.3 percent. Critical habitat features include the confluence of Tryon Creek and the Willamette River. Land use in this area is predominantly residential; however, the Tryon Creek Water Treatment Plant is located on the south shore of this reach and directly discharges into the Willamette River.

Tryon 2: Lower Canyon

HWY 43 to Nettle Creek confluence (RM 0.24 to 1.06; 4,330 feet)

Although the hillside was completely logged approximately 40-6o years ago, the area is now designated as greenspace and is largely undisturbed within the confines of Tryon Creek State Natural Area. One exception is a sewer pipe that runs along the valley bottom. Several tributaries enter the lower canyon near the upper end of the sub-reach. Land use in the drainage is split between park (along the riparian corridor) and low-density residential (in upland areas).

Tryon 3: Tryon Creek Park

(RM 1.06 to 2.68; approximately 8,554 feet)

Tryon 3A

Nettle Creek to Park Creek confluence (RM 1.06 to 1.80; 3,96o feet)

This sub-reach has a stream gradient of o.6 percent. Vegetative canopy is nearly entire, with well-established second-growth forest. Three tributaries (Red Fox Creek, Palatine Hill Creek, and Park Creek) enter the sub-reach, and Park Creek marks the upper boundary of the sub-reach.

Walking trails cross and parallel the creek through approximately one half of the sub-reach, and there are two footbridges. Tryon Creek State Natural Area bounds the drainage basin.

TRYON $_{3} \mathrm{~B}$

Park Creek confluence to the confluence of Tryon Creek and Arnold Creek (RM 1.8o to $2.68 ; 4,640$ feet) 
This sub-reach has a stream gradient of o.8 percent. Although the reach runs through a well-established forest stand, numerous trails run through the reach, and human and horse activity is high. The upper extent of the sub-reach ends at the confluence of Tryon Creek and Arnold Creek, immediately above SW Boones Ferry Road. The SW Boones Ferry Road culvert is approximately 150 feet long and is considered completely impassable to anadromous and resident fish. Tryon Creek State Natural Area generally bounds the drainage basin; some low-density residential areas exist in the uplands.

Tryon 4: Upper Tryon Creek

(RM 2.68 to $4.02 ; 7,076$ feet)

This reach comprises six sub-reaches, based on distinct hydrologic, habitat, and land use regimes.

Tryon 4A

Upper Tryon Park (RM 2.62 to 3.28; approximately 3,485 feet)

This reach segment has a stream gradient of 2.3 percent. It includes SW Maplecrest Drive (100 feet long), which bounds the upper extent of the reach. Mature secondogrowth forests dominate the landscape. Some low-density residential use is found in the uplands.

[Tributary T1 runs parallel to SW Boones Ferry Rd. and meets Tryon Creek north of the Arnold Creek tributary - There are observations of moderate incision and some bank failure.]

[Reach T1 and Reach T 2 - There is sediment deposit and moderate channel incision around the SW Boones Ferry Rd. crossing. The combination of channel incision and lack of streamside vegetation have resulted in bank erosions on both sides of Tryon Creek. There are a few woody debris jams that are suggested to be left in place for the storage of sediment.]

Tryon $4 \mathrm{~B}$

SW Maplecrest Drive to Marshall Boulder Cascade (RM 3.28 to 3.48; approximately 1,056 feet)

This reach is generally similar to Tryon $4 \mathrm{~A}$, except that land use is dominated by low-density residential development (with landscaped vegetation in the riparian zone and along southwest facing slopes). Marshall Cascade (a run of rock pools and steps) bounds the upper end of this sub-reach.

[Reach $\mathrm{T}_{3}$ - Bank failure potentially in response to management of riparian vegetation is noted. The floodplain of this portion of the stream is within Marshall Park, with low shrub cover and impervious surfaces such as a basketball court.] [Tributary $\mathrm{T}_{2}, \mathrm{~T}_{3}$, and $\mathrm{T}_{4}$ - These tributaries are mostly moderately incised with some instances of incision to the bedrock or clay layers, leading to bank failure. There is presence of streamside vegetation, including shrubs. Tributary T2 flows through an underground pipe east of SW Terwilliger Blvd. Tributary T3 lacks woody debris within the stream channel and has instances of exposed pipes. Residential buildings in Tributary $\mathrm{T}_{3}$ are located near significant valley slope failure. Side- 
cutting and sediment deposition have occurred as a result of backwater around a culvert just upstream of the Tributary $\mathrm{T}_{4}$ confluence with Tryon Creek.]

Tryon $4 \mathrm{C}$

Marshall Cascade to SW 18th Place culvert (RM 3.48 to 3.55; 3,696 feet)

Four to five tributaries enter Tryon Creek in this sub-reach, including Burlingame Creek. The SW 18th Place culvert (approximately 70 feet long) is located at the upper end of the sub-reach, immediately above Marshall Cascade.

[Reach $\mathrm{T}_{4}$ and Reach $\mathrm{T}_{5}$ include Tryon ${ }_{4} \mathrm{C},{ }_{4} \mathrm{D}$, and ${ }_{4} \mathrm{E}-\mathrm{A}$ boulder cascade is present in Reach $\mathrm{T}_{4}$. There is moderate channel incision and stream bank failure throughout Reach $\mathrm{T}_{5}$, likely a result of the observed landscaping impacts, rock walls lining the channel, and loss of riparian vegetation or shrubs. Exposed pipelines were also prevalent.

Tryon 4D

SW 18th Place to SW Lancaster Drive (RM 3.55 to 3.98; 2,270 feet)

Quail Creek defines the upper end of this short, 850-foot sub-reach. The hydrology is predominantly perennial flow, but sections become perennial-surface flow (i.e., dispersed and shallow flow) in bedrock areas. Land use is a mixture of park and lowdensity residential.

Tryon $4 \mathrm{D}$ (continued)

Quail Creek to SW Lancaster Drive (RM 3.92 to 4.11; 1,050 feet)

This sub-reach ends at the upstream end of the SW Lancaster Drive culvert, which is approximately 80 feet long. Land use is exclusively residential, with significant landscaping and only a partial tree canopy. Stream gradient is approximately 3.7 percent, with two short reaches of much steeper gradient.

Tryon $4 \mathrm{E}$

SW Lancaster Drive to SW 26th Avenue/Taylors Ferry Road (Falling Creek) (RM 3.98 to 4.03 ; 265 feet)

This sub-reach is very short (260-280 feet) with $2 \%$ stream gradient. Land use is residential, and the riparian canopy is limited. The confluence with Falling Creek defines the upper extent of the sub-reach.

Tryon 5: Headwaters

(RM 4.03 to > 4.85; approximately/over 3,69o feet)

The headwater section of Tryon Creek is enclosed in residential development, commercial development, and transportation uses, and is divided into five subreaches based on culvert locations.

Tryon 5 A

SW Taylors Ferry Rd. To Interstate 5/SW Barbur Culvert (RM 4.16 to 4.32; 845 Feet) This reach extends from Falling Creek to the bottom of I-5/SW Barbur Boulevard. The downstream reach is dominated by a series of five closely spaced streets and driveway culverts (near the intersection of SW 26th Ave and Taylors Ferry Road). Four closely spaced culverts (approximately 320 feet total length) bound the upper 
extent of the sub-reach. Stream gradient is $2 \%$. Residential development and landscaped lawns dominate the land use in the area and characterize the riparian and floodplain land base.

[Reach T6 - Bank incision, which is often associated with stream bank failure, ranges from moderate to cut all the way to the bedrock. The presence of landscaping and lack of vegetation and shrubbery cause a lack of shade, resulting in higher water temperature and poor fish habitat.]

Tryon $5 \mathrm{~B}$

I-5/SW Barbur Boulevard to end of open reach below SW Dolph Court (Rm 4.32 to 4.46; 740 Feet)

This reach begins with the long approximately 580 feet) I-5/Barbur Boulevard culvert. Commercial development and arterial roads dominate the landscape and land -use. As a result, stormwater runoff (from impervious surfaces) is significant throughout the sub-reach. The upper $150-160$ feet of the sub-reach is an open channel, and the sub-reach ends just below an industrial parking lot near Dolph Court.

$\left[\mathrm{T}_{7}\right.$ - This stream channel is partially piped].

Tryon $5 \mathrm{C}$

SW Dolph Court to bottom of culverts below SW 3oth Avenue (RM 4.46 to 4.56; 530 Feet)

This short reach terminates at an apartment complex (and culverted stream segment) just below SW 3oth Avenue. Wetland habitat exists immediately above SW Dolph Court.

[Reach T8 includes ${ }_{5} \mathrm{C},{ }_{5} \mathrm{D}$, and ${ }_{5} \mathrm{E}$ - The water level is low and flows partially underground. The portions that are open channel have moderate channel incision. The Dolph Ct. culvert has caused sediment deposition.]

Tryon $5 \mathrm{D}$

SW 30 th Avenue to end Of SW Carson Street (RM 4.56 to 4.85; 1,530 Feet)

This sub-reach is the uppermost segment on Tryon Creek. The SW 3oth Avenue culvert is approximately 160 feet long and defines the downstream extent of the subreach. A series of three closely spaced culverts (approximately 260 feet in total length) bound the upper extent of the sub-reach. Stream corridor characteristics from above SW 3oth Avenue to SW Carson Street are highly variable. Storm runoff is a dominant component of hydrology in these sub-reaches, and land use is primarily moderate-density residential.

Tryon $5^{\mathrm{E}}$

Headwaters Complex (includes all small upper tributaries above RM 4.85)

The headwater complex is a series of intermittent stream segments, all flowing into mainstem Tryon Creek. Although stream flow is seasonally intermittent, peak flows probably impact water quality and hydrologic processes in downstream creek reaches. 


\section{Tributaries to Tryon Creek}

Tributaries are presented in ascending geographic order in the sub-basin. They include lower canyon tributaries (Nettle, Palatine Hill, Red Fox, Park and Fourth Avenue Creeks); Arnold Creek; upper tributaries (Burlingame and Quail Creeks), and Falling Creek. Arnold Creek and Falling Creek are believed to significantly impact habitat and hydrologic functions in the Tryon Creek sub-basin and are characterized in more detail than lower canyon tributaries and upper tributaries.

Lower Canyon Tributaries

Nettle Creek, Palatine Hill Drainage, Red Fox Creek, Park Creek, and Fourth Avenue Creek

Thorough habitat surveys have not been conducted in these lower Tryon Creek tributaries; detailed habitat descriptions are therefore not available. However, lower tributary segments flow into and are bound by Tryon Creek State Natural Area and are considered to have an intact forest canopy, high riparian integrity, and variable hydrology. The upper reaches of all these creeks are in low-density residential development.

Nettle Creek

Nettle Creek enters Tryon Creek at RM 1.15 (Tryon 2/Tryon 3A reach break). The mainstem reach is approximately 1.7 miles long. It is about 75 percent residential land use and lies within Lake Oswego and Multnomah County.

Palatine Hill Drainage

Palatine Hill Creek is approximately 0.5 mile long. It is $40-50$ percent residential land use and is largely contained in Multnomah County.

Red Fox Creek

Red Fox Creek is approximately 0.7 miles long. It is 50 percent residential land use and lies primarily within the City of Lake Oswego.

Park Creek

Park Creek enters Tryon Creek at RM 2.82 (Tryon 2/Tryon 3A reach break) and is approximately 1.0 mile long. It is $50-60$ percent residential land use and lies within Multnomah County and the City of Portland.

Fourth Avenue Creek

Fourth Avenue Creek is approximately 0.7 mile long. About 40 percent of the subbasin lies within the property limits of Lewis \& Clark College; the remainder lies within

Tryon Creek State Natural Area and the City of Portland.

Arnold Creek Reach

Mouth of Arnold Creek to above SW 43rd Avenue (RM o.o to 1.84; approximately 9,70o feet)

Approximately 8o percent of Arnold Creek sub-basin is in residential land use (within the City of Portland). Arnold Creek is divided into six sub-reaches; however, detailed habitat and biological community surveys have been done for only sub- 
reaches Arnold ${ }_{1} \mathrm{~A}$ and Arnold ${ }_{1} \mathrm{~B}$. Low flows within Arnold Creek and a cascade reach just below $S W{ }_{16}$ th Place (Arnold ${ }_{1 B} B$ ) probably isolate fish populations. At least eight tributaries enter Arnold Creek; these are not included in this characterization report.

Arnold $1 \mathrm{~A}$

Mouth of Arnold Creek to SW Arnold Road (RM o.o to o.13; Approximately 680 Feet) This reach begins at the confluence of Tryon Creek and Arnold Creek. The reach is heavily wooded, with a dense canopy (except along SW Arnold Street, which runs parallel to the creek). Some of the sub-reach lies within Tryon Creek State Natural Area. Stream gradient is less than 1 percent. The SW Arnold Street culvert (approximately 50 feet long) defines the upper end of the sub-reach.

[Reach $A_{1}$ - This reach is moderately incised with significant sediment deposits at the confluence with Tryon Creek. An iron pipe with an 8-inch-diameter is exposed. Soils are described as highly consolidated clay.]

Arnold ${ }_{1 B} \mathrm{~B}$

SW Arnold Road to above SW 16th Place (Cascade Reach) (RM o.13 to $0.41 ; 1,480$ Feet)

Stream gradient averages 6 percent. This sub-reach is believed to be the end of anadromy, and the ODFW (2001) habitat surveys ended here. SW Arnold Street continues to parallel the stream at a distance of 50-75 feet to the north. The SW 16th Place culvert bounds the upper extent of the sub-reach.

[Reach A2 - Moderate incision and some lateral migration have led to bank instability failure.]

Arnold ${ }_{1} \mathrm{C}$

SW 16th Place to SW Lancaster Road (Middle Arnold) (RM 0.41 to o.78; 1,950 Feet)

Stream gradient is 1.8 percent. The predominant land use in the sub-reach is residential, with several driveway culverts crossing the stream channel. SW Arnold Street continues to parallel the sub-reach along the north slope. The SW Lancaster Road culvert (approximately 110 feet long) marks the upper extent of the sub-reach.

[Reach A3 - A boulder cascade marks the upstream end of this stream reach. Light to moderate incision occurs throughout. There are a few woody debris jams that should be left in place to prevent incision. A vital shrub component is present in the areas where streamside landscaping isn't present.]

Arnold ${ }_{1} \mathrm{D}$

SW Lancaster Road to SW 31st Avenue (RM o.78 to 1.15; 1,950 feet)

Stream gradient is approximately 3 percent; this sub-reach is otherwise similar to Arnold ${ }_{1} C$. The SW 3ist Avenue culvert bounds the upper extent of the sub-reach.

[Reach $\mathrm{A}_{4}$ and Reach $\mathrm{A}_{5}$ - Moderate incision and some bank failure are present. Residential development is present in the floodplain of Reach $\mathrm{A}_{4}$, yet areas not affected by proximity to houses, there are woody debris jams. Reach $\mathrm{A}_{5}$ is in fairly 
good condition due to properly landscaped stream rehabilitation. Reach $\mathrm{A}_{5}$ is characterized as a riffle/pool sequence with occasional woody debris jams, and streamside vegetation and shrubs that prevent bank failure and shade the stream.] [Reach $\mathrm{O}_{1}$ -

Arnold ${ }_{1} \mathrm{E}$

SW 31st Avenue to SW 35th Avenue (Arnold Headwaters) (RM 1.15 to 1.42; 1,430 Feet) Stream gradient is 6.3 percent. The long SW 35th Avenue culvert (approximately 100 feet) defines the upper end of this sub-reach.

[Reach A6 - There is moderate to heavy stream incision throughout the reach that extends to the bedrock in some areas.]

[Tributary A8 and tributary A9 - There is a high potential for sediment input in Tributary A8 due to steep stream grade and a narrow valley with a high occurrence of valley slope failure. At the time of survey, the undersized culvert near the end of Tributary A8 was filled with sediment, causing the stream to flow over the culvert. Tributary A9 flows mostly on bedrock due to high level of incision. Both banks of Tributary A9 exhibit some moderate bank failure. Several pipes are exposed along Tributary A9.]

Arnold ${ }_{1} \mathrm{~F}$

Arnold Headwaters (RM 1.42 to 1.84)

This headwaters reach is predominantly in public land ownership. It is over 2,500 feet long, with a gradient of approximately 8 percent.

[Reach $\mathrm{A}_{7}$ - There is moderate to heavy incision throughout this reach, leading to a bedrock or clay/rock stream subsurface. Stormwater runoff enters the stream in at least one point.]

Upper Tributaries

The upper tributaries include Burlingame Creek and Quail Creek. Detailed habitat descriptions (and other instream and riparian data) are not available for these two reaches. A brief description of dominant land-use by reach is provided below.

Burlingame Creek

Burlingame Creek flows into Tryon Creek near RM 3.89 (Tryon $4 \mathrm{D}$ ). The creek is approximately one mile long. About 90 percent of the drainage is zoned residential land use within the City of Portland.

Quail Creek

Quail Creek flows into Tryon Creek near RM 3.92 (near the upper extent of Tryon 4D). The creek is approximately 0.5 mile long. More than 90 percent of the drainage is zoned residential land use within the City of Portland.

[Reach Q1 and Reach Q2 - Moderate incision and associated bank failure are present along the lower reach of Quail Creek, resulting in channel flowing on clay or bedrock. Rocks have been placed in some portions which are characterized as in fair condition. The streamside vegetation along most of the creek is landscaped.] 
Falling Creek Reach

Falling Creek is approximately one mile long. The Falling Creek drainage lies within residential urban development, roads, and parks. Limited data are available that characterizes instream channel condition and riparian and floodplain characteristics. Culverts divide Falling Creek into three sub-reaches: Falling $1 \mathrm{~A}$,

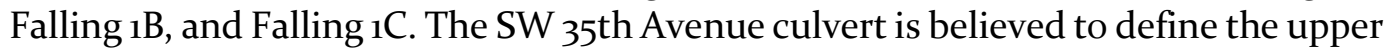
limit of fish habitat in Falling Creek, but this assumption has not been confirmed.

Falling $1 \mathrm{~A}$

Mouth of Falling Creek to SW 26th Avenue (Lower Falling) (Approximately zo Feet) This sub-reach begins at the confluence of Falling Creek and Tryon Creek (RM 4.16: Tryon $4 \mathrm{E}$ ).

Stream gradient is approximately 2.5 percent. Land use is predominantly multiplefamily residential, with a large number of apartments close to the stream corridor. SW Taylors Ferry Road and SW 35th Drive parallel the stream at distances between 100 and 300 feet. The SW $35^{\text {th }}$ Avenue culvert defines the upper extent of the subreach; the culvert is approximately 150 feet long and has a gradient of 6.5 percent.

[Reach F1 includes Falling $1 \mathrm{~A}$ and $1 \mathrm{~B}$ - This reach is characterized to be moderately incised with moderate to severe bank erosion in many areas.]

Falling $1 \mathrm{~B}$

SW 26th Avenue to SW 35th Avenue (Approximately 3,500 Feet)

No information reported.

Falling ${ }_{1} \mathrm{C}$

SW 35th Avenue to SW Huber Street (Approximately 1,500 Feet)

Stream gradient is $\mathbf{2 . 2}$ to 2.5 percent. Land use is primarily residential, although the lower half of the sub-reach has few structures. The sub-reach ends immediately above the SW Huber Street culvert, which is approximately 6o feet long.

[Reach F2 - Moderate incision is present throughout this reach. Landscaping covers most of the stream banks with a diminished shrub component.]

Falling $1 \mathrm{D}$

SW Huber Street to Jackson Middle School (Upper Falling) (Approximately 200 Feet)

No information reported.

[Reach $F_{3}$ includes Falling $1 \mathrm{D}$ and ${ }_{1} \mathrm{E}$ - The stream flows mostly underground and beneath Jackson Middle School. The parts of the creek that are exposed here have high prevalence of landscaping along the streamside with few shrubs. Houses and landscaping such as lawns are developed within the floodplain.]

Falling $1 \mathrm{E}$

Jackson Middle School (1,80o Feet) 
The majority of this creek segment is buried (piped) under Jackson Middle School playfields. The lower portion of the reach lies within a residential neighborhood." (City of Portland, 2005).

[Reach F4 runs above Comus Street - Most of the stream in this reach flows through underground pipes with the remaining subjected to the presence of landscaping. 


\section{Conclusion}

The Upper Tryon Creek Corridor Assessment describes sections of Tryon Creek as moderately incised and eroded, which in combination with nearby commercial and residential presence leave it vulnerable to natural and human influences (City of Portland, 1997). Other noted channel characteristics reported in the Corridor Assessment were stream bank failure, lack of woody debris, lateral migration, with most instances resulting issues are either sediment deposition or erosion to the bedrock. Further responses to variable width/depth ratios within streams are vulnerability to peak flows and elevated water temperatures, which consequently have negative effects on wildlife, especially salmonids (Rhodes, 2002). Observed human activities often associated with stream issues are landscaping with a lack of the vital riparian vegetation, impervious surfaces such as roads and building within the floodplain, agriculture with potential nutrient loading effects on the stream, and structures within the stream including culverts and exposed pipes. In 2002, Klatte and Ellis also observed stream bank erosion within Tryon Creek State Natural Areas in locations that have undergone high frequency of park visitors causing trail erosion and cross drain failure. While there were also activities of positive stream health maintenance including the preservation of woody debris jams that enhance aquatic habitat and can reduce stream velocity consequently reducing erosion and later sediment deposition.

The nine primary stream reaches described by the City of Portland in the Fanno and Tryon Creeks are mapped in figure 3.1. They vary in length and channel habitat type and some boundaries are set by human-made structures, such as the transition from Tryon 1: Confluence to Tryon 2: Lower Canyon that is defined by the presence of Highway 43. Tryon 1: Confluence can be characterized as primarily residential with a low stream gradient. The two major features of this stream reach are the Tryon Creek Water Treatment Plant and the confluence with the Willamette River. Tryon 2: Lower Canyon contains a portion of the Tryon Creek State Natural Area and therefore greenspace that has been undisturbed since logging ended in the mid-19oos. Besides the park, land use within Tryon 2 is primarily low-density residential. Tryon 3: Tryon Creek Park includes the mainstem of the creek that covers a majority of the state park. The second-growth forest provides a heavy vegetative canopy. Several lower canyon tributaries enter throughout this stream reach with low stream gradient of about 0.7 percent. Moving upstream, the next section is Tryon 4: Upper Tryon Creek that comprises of mainstem Tryon and a few smaller tributaries. This stream reach is varied throughout and can be characterized by some instances of second-growth trees as well as landscaping associated with the range of low to high-density residential land use. The final portion of Tryon Creek mainstem is Tryon 5: Headwaters, which is heavily concentrated with residential and commercial development, including dense roads and highways. Culverts and stormwater runoff are both prevalent components of this segment of the creek. The channel habitat of the Lower Canyon Tributaries is less studied, yet it is known that they have second-growth forest cover and flow from residential headwaters and enter Tryon Creek within the state park. Stream profile and channel slopes were modeled for Tryon Creek mainstem as well as the Falling and Arnold Creek Tributaries (Figure 3.2A-C). All three figures demonstrate a steep slope along the channels, especially that of the mainstem of Tryon Creek. Locations of flatter lines indicate likely sediment deposition. One of the largest tributaries of Tryon Creek is Arnold Creek, and of the land it flows through, about $80 \%$ is residential with varying amounts of riparian coverage. Several of the stream reaches of Arnold Creek contain culverts. There are two creeks within the Upper Tributaries stream reach, yet habitat descriptions are not available. The final reach described by the City of Portland is the Falling Creek Reach which flows through primarily residential land and is notable piped where it passes by Jackson Middle School (City of Portland, 2005). 


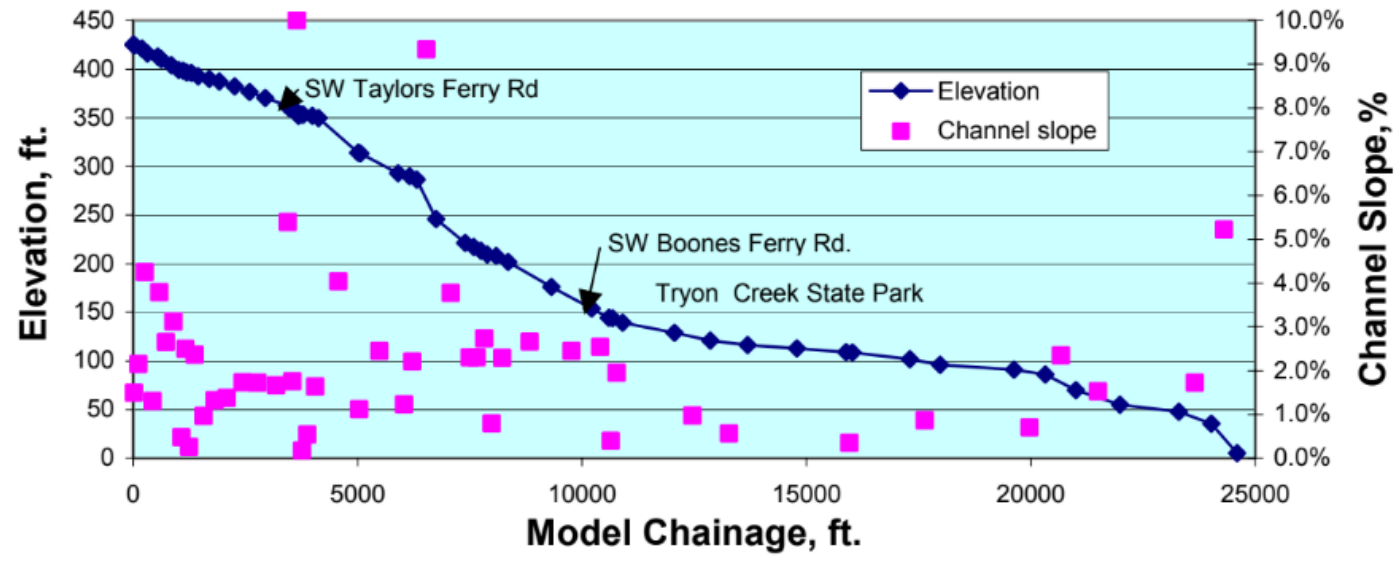

Figure 3.2A Model stream profile and channel slopes for Tryon Creek (Source: City of Portland).

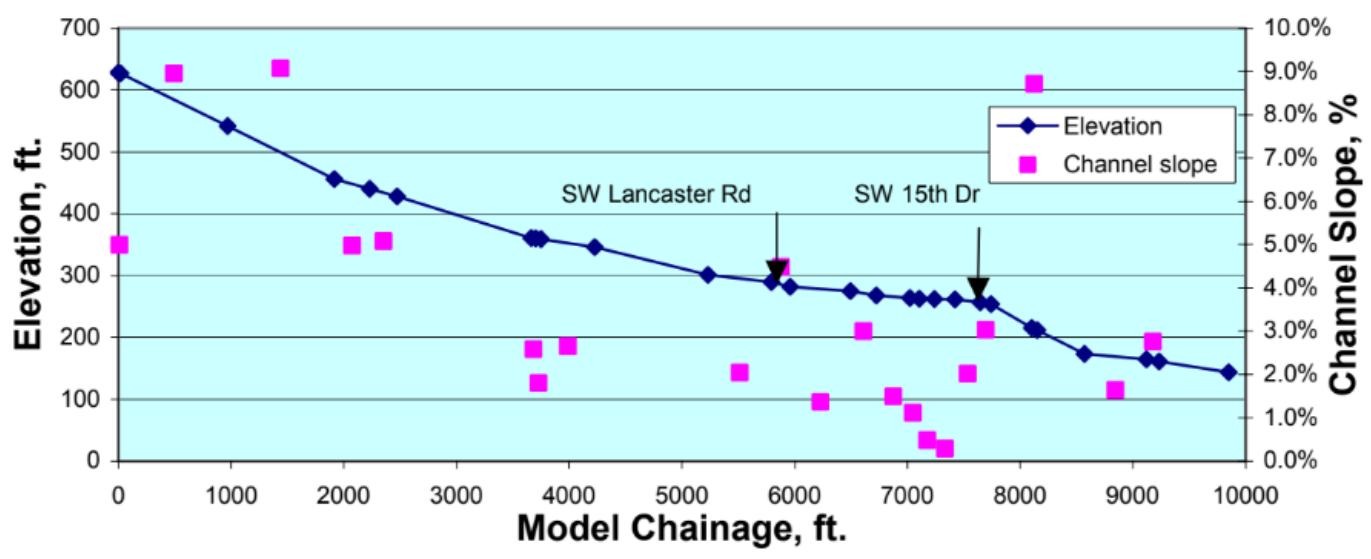

Figure 3.2B Model stream profile and channel slopes for Arnold Creek (Source: City of Portland).

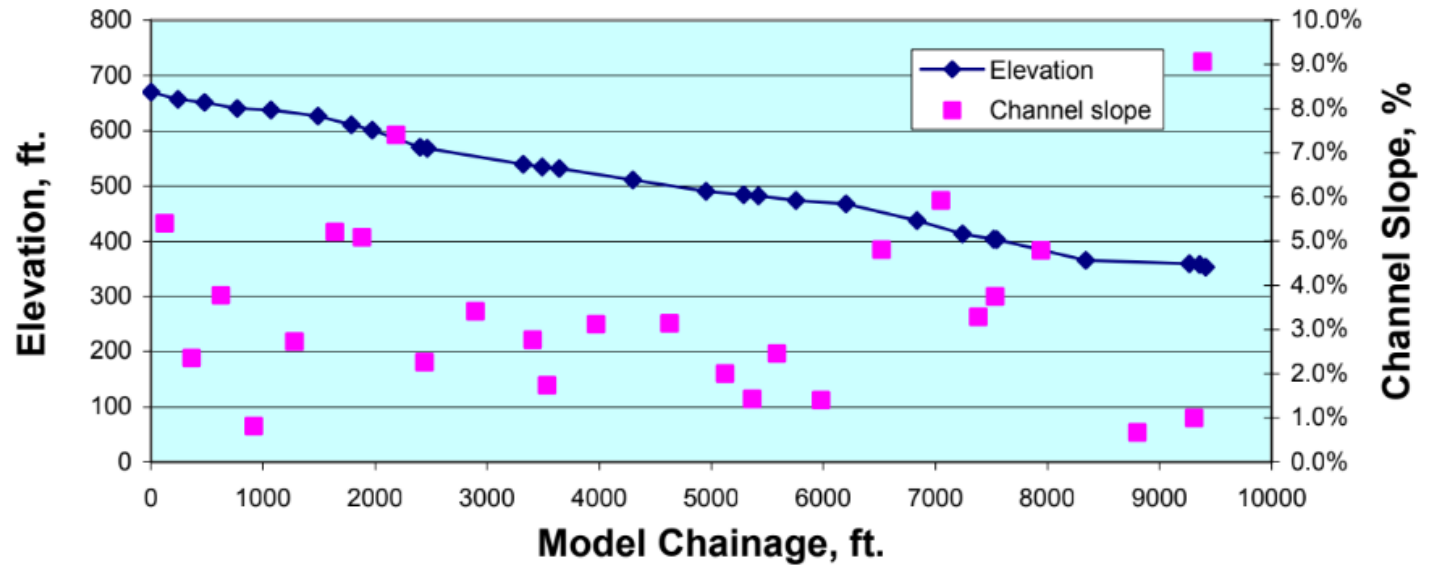

Figure 3.2C Model stream profile and channel slopes for Falling Creek (Source: City of Portland). 


\section{Data Gaps}

As an urban environment that is constantly changing and responding to human and natural influences, the current channel habitat of Tryon Creek may differ than that concluded on in 2005. Additionally, data collection for the Fanno and Tryon Creeks Management Plan did not include recording channel habitat descriptions for multiple tributaries. I would suggest that similar methods are followed to collect comparable results for the assessment of the channel habitat of all stream reaches in their current state, with special attention made to areas of bank incision, erosion, sedimentation, and other channel integrity issues.

\section{References}

City of Portland, Bureau of Environmental Services (1997). Upper Tryon Creek Corridor Assessment. City of Portland Bureau of Environmental Services.

City of Portland, Bureau of Environmental Services (2005). Fanno and Tryon Creeks Watershed Management Plan. City of Portland Bureau of Environmental Services.

City of Portland, Bureau of Environmental Services (2009). Tryon Creek Confluence Habitat Enhancement Design Report. City of Portland Bureau of Environmental Services.

Klatte, B. \& Ellis, R. (2002). Tryon Creek Environmental Baseline Conditions and Limiting Factors Analysis for Anadromous Salmonids. West Multnomah Soil and Water Conservation District.

Moore, K., et al. (2019). Aquatic Inventories Project. Conservation and Recovery Program. Department of Fish and Wildlife. Corvallis, Oregon.

Paustian, S., et al. (1992). A Channel type user's guide for the Tongass National Forest, Southeast Alaska. Juneau, Alaska: U.S. Dept. of Agriculture, Forest Service, Alaska Region. United States. Forest Service. Alaska Region.

Rhodes, J. (2002). Overview of Existing Condition, Data Gaps and Recommendations for the Protection and Restoration of Aquatic Resources. West Multnomah Soil and Water Conservation District.

Watershed Professionals Network (1999). Oregon Watershed Assessment Manual. Governor's Watershed Enhancement Board. Salem, Oregon. 


\section{HYDROLOGY AND WATER USE ASSESSMENT}

\section{Introduction}

Throughout the recorded history of Tryon Creek, there are many notable land use changes that ultimately have an effect on the hydrologic cycle of the watershed. The assessment of a watershed at this level of detail requires an understanding of all processes in and around a stream, including its hydrology. The effects of human activities such as riparian zone alteration should be evaluated in regard to the hydrology of the system. Specific attributes of a watershed including location, extent, and type of nearby activities determine the degree to which the hydrologic cycle is affected. One such action that affects the hydrologic function of a creek is burying, or forcing the creek through underground pipes, which is common throughout the headwaters of Tryon Creek. Within the Fanno and Tryon Creeks Watershed Management Plan, the City of Portland noted that in 2005 it was estimated that out of the 27.5 miles of Tryon, Arnold, and Falling Creeks, approximately 3.4 miles are in pipes or culverts (City of Portland, 2005). This is a common feature of urban streams that impact many attributes of the watershed health. In addition to land use, water use can cause changes in the hydrologic cycle, potentially altering the patterns of high and low flows of the stream, consequently impacting the water quality and aquatic ecosystems (Watershed Professionals Network, 1999). High peak flows affect the riparian environment through increased erosion, increasing sediment loads, and transportation of large woody debris that provide habitat for wildlife. The low flows of a stream can interrupt wildlife paths and alter water chemistry and temperature. Additionally, further decreasing of summer base flows has negative impacts on summer rearing of fish species that find their pools are without water.

\section{General Watershed Characteristics}

The Tryon Creek stream network contains streams that flow year-round as well as those that flow only part of the time (City of Portland, 2005). The streams that flow throughout the year and have an estimated base flow and storm flow are referred to as perennial. Those that flow only during storm events are ephemeral streams. Intermittent streams flow for longer periods, usually weeks or months, during rainy seasons. The sources of Tryon Creek are composed of headwaters and drainages. The role of the headwaters and intact streams for the health of the watershed are numerous and can provide "natural flood control, recharge groundwater, trap sediments and pollutions from fertilizers, recycle nutrients, create and maintain biological diversity, and sustain the biological productivity of downstream rivers, lakes, and estuaries" (City of Portland, 2005). Figure 4.1 shows the seasonal shift of discharge (cfs) as well as "flashy" responses to storm events throughout the year. Rainier months (October-April) reflect more variation in cfs from day to day, demonstrating that impervious surfaces, steep slopes, and precipitation have a large effect on the discharge and other characteristics of hydrology. The stream gauge that collected this data is located near the confluence of Nettle Creek and Tryon Creek. 


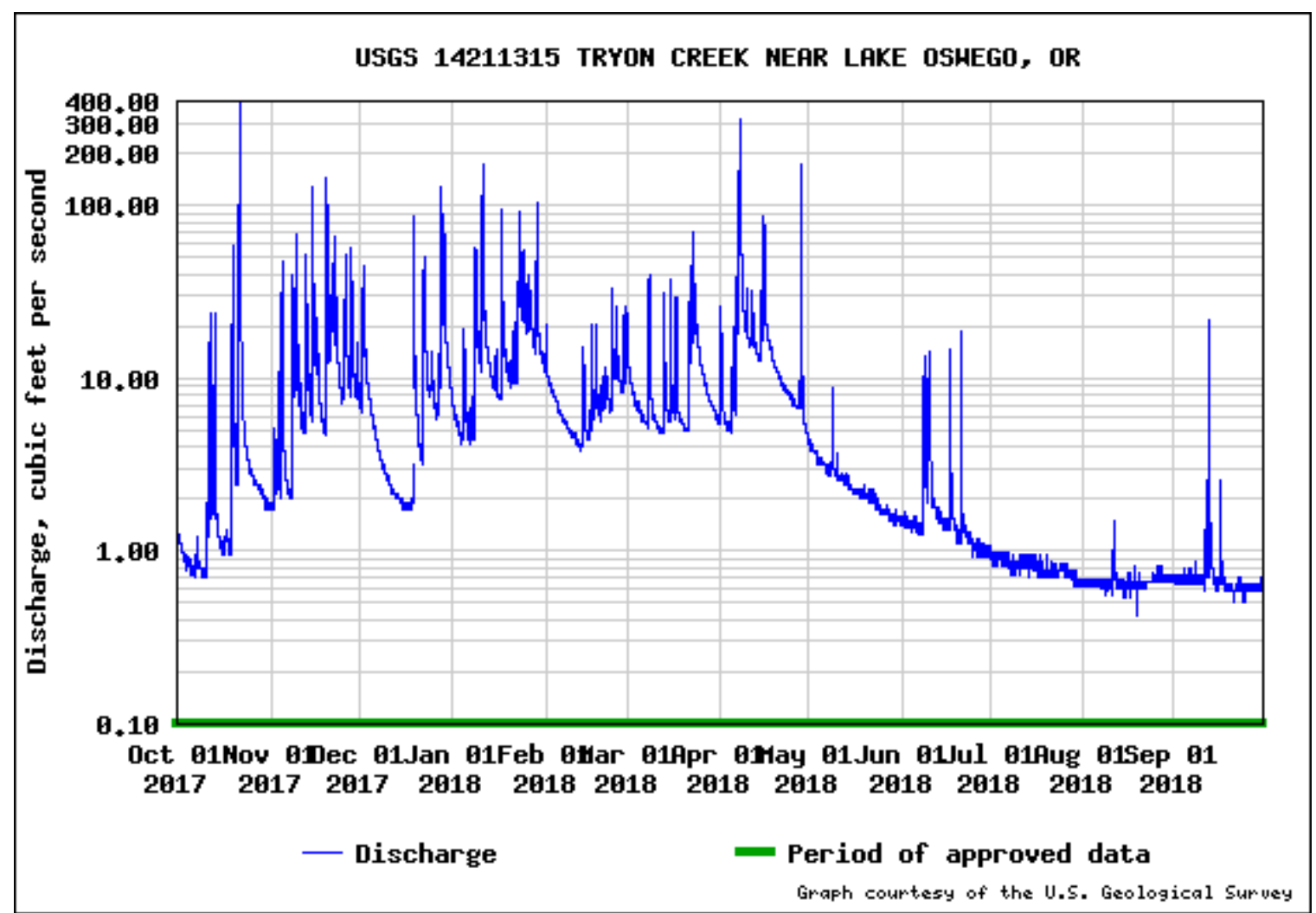

Figure 4.1 Recorded daily discharge for the year of 2018 (Source: United States Geological Survey).

Through an understanding of the hydrologic cycle, watershed planning and management can be done with a prediction of potential impacts of land and water use. The hydrologic cycle is a complex web of flow and storage of water. It is estimated that of the total annual precipitation in the Tryon Creek watershed, $\mathbf{2 2} \%$ is direct runoff to the stream, $25 \%$ is subsurface runoff to the stream, $7 \%$ drains to the stream as base flow, and $46 \%$ is lost to evapotranspiration (City of Portland, 2005). Although the hydrologic cycle is too complicated to fully cover in this assessment, it will enlighten interpretation of data and management decisions in the future.

The Tryon Creek watershed consists of steep slopes and drainage basins of various sizes determined by topography. The basins flow into the Tryon Creek mainstem, which converges with the Willamette River. The combination of steep slopes and urbanization have led to concern about peak flows during storm events. During days of high precipitation, rain flows off of the impervious surfaces of streets and buildings and is often diverted directly to the stream through stormwater drainage systems (City of Portland, 2012). While the cities of Portland and Lake Oswego work to improve existing roads, it is also important to learn about precipitation patterns to better predict peak flows of Tryon Creek. Figure 4.2 portrays the average monthly precipitation of Portland based on data from 1981 to 2010 (U.S. Climate Data, n.d.). These data were gathered from a weather station within Portland and may vary slightly from the averages observed in the Tryon Creek watershed, although it can be used as an estimation reference for the purposes of this watershed assessment. Precipitation data specific to Tryon Creek or Lake Oswego were not found. Note that the general trend of precipitation values reflects that of discharge displayed in figure 4.1. Peak flows in riparian environments are heavily impacted by impervious areas including roads and infrastructure, soil loss, and compaction (Rhodes, 2002). 


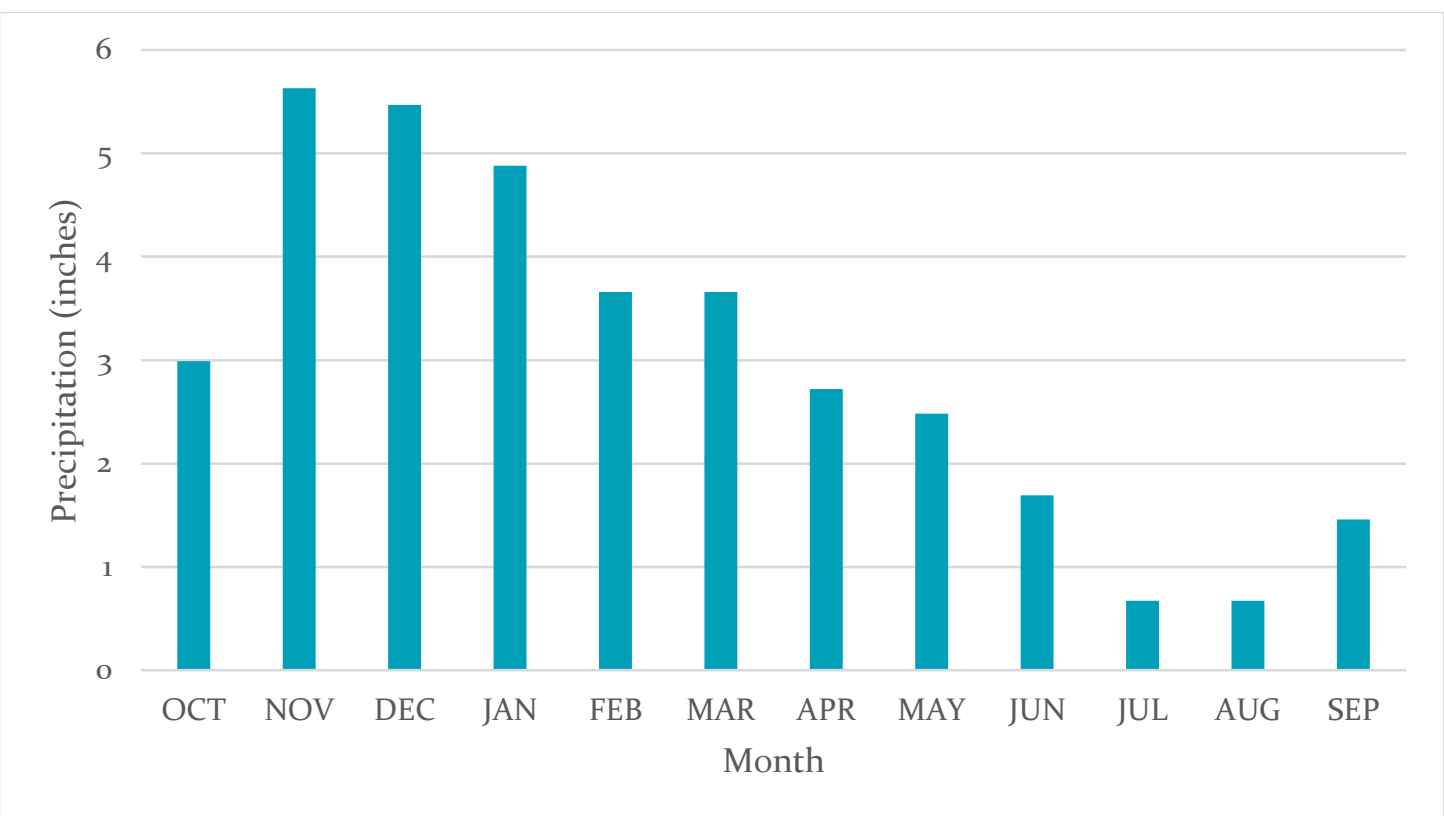

Figure 4.2 Recorded monthly precipitation for Portland, averaged for the years 1981-2010 (Source: United States Climate Data).

\section{Hydrologic Condition Assessment}

There is one active stream gauge in the watershed located just downstream of where Nettle Creek meets Tryon Creek monitored by USGS (USGS Gauge 14211315), roughly 1.0 mile upstream of the Willamette River confluence. This gauge provides data which is updated on a daily basis and goes as far back as August 2001. Based on peak flow data that ranges from 2002 to 2017, storm peak flows have varied between $206 \mathrm{cfs}$ in 2005 to $1210 \mathrm{cfs}$ in 2011 (table 4.1). Table 4.1 highlights characteristic statistics for Tryon Creek and each of its main tributaries accessed from USGS via the Stream Stats website. Tryon Creek within the table is the entirety of the watershed, including the tributaries listed within the table. These data reflect a trend that precipitation increases with elevation (Waring, et al., 1981). Average annual precipitation is also informative for watershed management activities. The magnitudes of five predicted peak flow for the entire creek and main tributaries are displayed in table 4.1. A few of the more recently recorded peak flows in table 4.1 are much larger than the predicted storm flows of table 4.2. It is possible that the predictions based on the work of Cooper (2005) did not account for factors associated with increased urbanization because the model used is intended for rural, unregulated streams of western Oregon. 
Table 4.1 Peak flows recorded by the Tryon Creek stream gauge (Source: United States Geological Survey).

\begin{tabular}{|l|l|}
\hline \multicolumn{1}{|c|}{ Date } & Peak flow $(\mathrm{cfs})$ \\
\hline $2 / 23 / 2002$ & 340 \\
\hline $1 / 31 / 2003$ & 447 \\
\hline $12 / 13 / 2003$ & 520 \\
\hline $9 / 30 / 2005$ & 206 \\
\hline $11 / 1 / 2005$ & 371 \\
\hline $12 / 14 / 2006$ & 279 \\
\hline $12 / 3 / 2007$ & 347 \\
\hline $6 / 6 / 2010$ & 730 \\
\hline $12 / 9 / 2010$ & 1210 \\
\hline $1 / 19 / 2012$ & 1170 \\
\hline $11 / 19 / 2012$ & 552 \\
\hline $3 / 28 / 2014$ & 324 \\
\hline $1 / 17 / 2015$ & 437 \\
\hline $2 / 5 / 2017$ & 837 \\
\hline
\end{tabular}

Table 4.2 Hydrological watershed characteristics for the Tryon Creek Watershed including predicted peak flows (Source: United States Geological Survey).

\begin{tabular}{|l|l|l|l|l|l|l|l|l|l|l|}
\hline & \multicolumn{4}{|c|}{ Topography (feet) } & \multicolumn{4}{c|}{ Frequency and Magnitude of } \\
\hline Watershed & $\begin{array}{c}\text { Area } \\
\text { (sq. } \\
\text { mi) }\end{array}$ & $\begin{array}{c}\text { Min. } \\
\text { Elevation }\end{array}$ & $\begin{array}{c}\text { Max. } \\
\text { Elevation }\end{array}$ & $\begin{array}{c}\text { Average } \\
\text { Elevation }\end{array}$ & $\begin{array}{c}\text { Average } \\
\text { Precipitation } \\
\text { (inches) }\end{array}$ & $\begin{array}{c}100 \\
\text { year }\end{array}$ & $\begin{array}{c}50 \\
\text { year }\end{array}$ & $\begin{array}{c}25 \\
\text { year }\end{array}$ & $\begin{array}{c}10 \\
\text { year }\end{array}$ & $\begin{array}{c}2 \\
\text { year }\end{array}$ \\
\hline Tryon Creek & 6.76 & 8.43 & 973 & 393 & 45.1 & 625 & 553 & 482 & 388 & 208 \\
\hline Arnold Creek & 1.21 & 159 & 973 & 503 & 45.5 & 140 & 124 & 108 & 87.6 & 47.4 \\
\hline Falling Creek & 0.53 & 361 & 686 & 536 & 46.2 & 55.7 & 49.4 & 43.2 & 34.9 & 19 \\
\hline Nettle Creek & 0.91 & 100 & 561 & 366 & 44.8 & 94.9 & 84.2 & 73.5 & 59.3 & 32.2 \\
\hline Park Creek & 0.6 & 141 & 566 & 406 & 45 & 69.2 & 61.5 & 53.8 & 43.5 & 23.6 \\
\hline
\end{tabular}

For the Tryon Creek Confluence Habitat Enhancement Design Project, the City of Portland utilized the MIKE-SHE and MIKE 11 for hydrologic modeling in 2009. These models were designed by the Danish Hydraulics Institute (DHI) and were used to estimate peak discharge values for Tryon Creek at the Hwy 43 culvert. Together the models simulate hydrologic, hydraulic, upland pollutant loading, and instream processes within a watershed through the integration of surface and groundwater estimates (City of Portland, 2005). Application for the Tryon Creek watershed involved the use of a 10o-foot-square grid network based on characteristics of the basin and predetermined constraints.

Peak stream flows were also estimated by the City of Lake Oswego in 2015 based on 13 years of the continuous flow data recorded at the USGS stream gauge (table 4.3). The City of Portland predicted flow magnitudes about $1 / 2$ to $1 / 3$ larger than those predicted by Stream Stats. In the Hydromodification Assessment, MacDonald (2005) notes that the gauge recordings range from 2 to 3.4 times the values estimated by Stream Stats equations. This is likely a sign of the effects of hydromodification of the urban stream. 
Table 4.3 Comparison of predicted storm flow between three modeling techniques (Source: City of Lake Oswego).

\begin{tabular}{|l|l|l|l|l|l|l|}
\hline & \multicolumn{5}{|c|}{ Frequency and Magnitude of Floods (cfs) } \\
\hline \multicolumn{1}{|c|}{ Data Source } & 100 Year & 50 Year & 25 Year & 10 Year & 5ear & 2 Year \\
\hline $\begin{array}{l}\text { Stream Stats and } \\
\text { Cooper, 2005 }\end{array}$ & 625 & 553 & 482 & 388 & 314 & 208 \\
\hline $\begin{array}{l}\text { City of Portland, } \\
\text { 2009 }\end{array}$ & 811 & $\begin{array}{l}\text { not } \\
\text { reported }\end{array}$ & 636 & $\begin{array}{l}\text { not } \\
\text { reported }\end{array}$ & 443 & 340 \\
\hline MacDonald, 2015 & $\begin{array}{l}\text { not } \\
\text { reported }\end{array}$ & $\begin{array}{l}\text { not } \\
\text { reported }\end{array}$ & $\begin{array}{l}\text { not } \\
\text { reported }\end{array}$ & 1200 & 700 & 400 \\
\hline
\end{tabular}

Further analysis by the City of Portland (2005) included GIS analysis to learn more about the influences of humans on hydrology through impervious areas, zoning, and the piped channels. The 10o-foot-square grids plotted for the MIKE models were used to proceed to the next step of dividing the watershed into drainage sub-catchments based on topography and modeled stream segments. The 18 sub-catchments were then combined into three drainage areas with the following descriptions:

- "Drainage Area 1 - This area includes the upper two sub-catchments, TRY329 (Falling Creek and TRY258, which drain the areas upstream from SW Taylors Ferry Road.

- Drainage Area 2 - This area includes all sub-catchments between SW Taylors Ferry Road and SW Boones Ferry Road. This drainage area includes the Arnold Creek tributary.

- Drainage Area 3- This area includes all the sub-catchments downstream of SW Boones Ferry Road and includes the area within Tryon Creek State Natural Area as well as significant area outside the City of Portland." -City of Portland, 2005

\section{Water Use}

The effects of water use are dependent on the withdrawal method and amount of water. Water use can intensify low flows during the summer and decrease water quality. Surface and ground water rights applications that are non-cancelled are listed in table 4.4. The Oregon Water Resources Department Water Rights Information Query Results were used to list these data and it should be noted that a few results came up as Tryon Creek and did not have sufficient information to retain on this list. There are 12 water rights applications listed in table 4.4 and it is likely that some of the water rights listed are no longer active because they date as far back as 1946. All but one of the water rights listed in table 4.4 are intended to be used for land less than 5 acres at the time of the water rights application, indicating that they are relatively smaller scale of use. 
Table 4.4 Water rights applications in the Tryon Creek watershed that are non-cancelled (Source: Oregon Water Resources Department).

\begin{tabular}{|l|l|l|l|l|}
\hline \multicolumn{1}{|c|}{ Street Address } & \multicolumn{1}{|c|}{ Type } & \multicolumn{1}{|c|}{ Use } & $\begin{array}{l}\text { Land Size at Time } \\
\text { of Application }\end{array}$ & Priority Date \\
\hline $\begin{array}{l}\text { SW Boones } \\
\text { Ferry Rd. }\end{array}$ & Surface water & Irrigation & 1.0 acres & 1938 \\
\hline SW Knaus Rd. & $\begin{array}{l}\text { Well into a } \\
\text { reservoir }\end{array}$ & Irrigation & 4.75 acres & 1946 \\
\hline $\begin{array}{l}\text { SW Taylors } \\
\text { Ferry Rd. }\end{array}$ & Surface water & Irrigation & 1.0 acres & 1946 \\
\hline $\begin{array}{l}\text { SW Taylors } \\
\text { Ferry Rd. }\end{array}$ & Surface water & Irrigation & 0.3 acres & 1951 \\
\hline SW Comus Rd. & Surface water & Irrigation & 1.15 acres & 1952 \\
\hline SW Lancaster & Surface water & Irrigation & 2.5 acres & 1953 \\
\hline $\begin{array}{l}\text { SW Taylors } \\
\text { Ferry Rd. }\end{array}$ & Surface water & Irrigation & 0.39 acres & 1955 \\
\hline SW 16 ${ }^{\text {th }}$ Dr. & Surface water & Irrigation & 2.5 acres & 1959 \\
\hline $\begin{array}{l}\text { SW Lancaster } \\
\text { Rd. }\end{array}$ & Surface water & Irrigation & 0.5 acres & 1967 \\
\hline SW Stanley Ct. & Surface water & Irrigation & 0.03 acres & 1962 \\
\hline Palatine Hill Rd. & $\begin{array}{l}\text { Well into } \\
\text { groundwater }\end{array}$ & Irrigation & 10 acres & 1992 \\
\hline SW Knaus Rd. & $\begin{array}{l}\text { Well into } \\
\text { groundwater }\end{array}$ & $\begin{array}{l}\text { Domestic and } \\
\text { irrigation }\end{array}$ & 1.3 acres & 2010 \\
\hline
\end{tabular}

\section{Conclusions}

Understanding of hydrologic processes and land use effects are important for further ability to predict summer water temperatures, sediment transport, and other watershed geomorphic functions (Williams, et al., 1997). Additionally, storm flooding is a concern for watershed health and property damage of structures close to the creek. Tryon Creek is surrounded by steep and unstable slopes that can lead to damaging landslides in the event of heavy rainfall (City of Portland, 2005). Because of the steep slopes and relatively impermeable soils, Tryon Creek is characterized as susceptible to high peak flows and low base flows, which are intensified by hydromodifications and changes of land use within the watershed. These transitions between high and low flows can be quite rapid, causing erosion and other harmful processes to the stream. Stream flow rates are likely to increase up to 20 to $30 \mathrm{cfs}$ within 15 minutes during heavy rain events and have even been recorded to increase from $2 \mathrm{cfs}$ to $200 \mathrm{cfs}$ within a day in the winter of 2008 (City of Portland, 2009). The MIKE SHE and other models applied by researchers discussed in this assessment were used to predict peak storm flows, which then can be applied to determine the minimum distance from the creek for storm drainage facilities to ensure that they are outside of 10-year storm flood zones. This is one of the many applications of hydrologic processes study through models. The City of Portland also mapped three drainage areas within Tryon Creek through the use of GIS analysis. Understanding of these drainage areas and the general flows of water from each point within the watershed will guide land use changes and stewardship efforts. Increased impervious surfaces resulting from development lead to runoff that flows directly to the stream at faster rates than in a natural system. The City of Portland (2009) notes that much of the development in the watershed took place during a time of fewer stormwater management requirements, leading to fewer instances of stormwater drainage and detainment on its way downslope to the creek. In addition, the 
contaminants that stormwater carries are known to affect spawning salmon and other wildlife species (Silver, et al., 2017).

Higher frequency of drainage networks and potential diversion of water to the creek results in unfiltered water entering directly into the creek and altering other functions, including water quality which will be discussed in section 8 (City of Portland, 2009). The connectivity of a watershed also affects the hydrologic functions. In the case of Tryon Creek, the floodplain connectivity of the upper reaches and many other sections is poor due to channel modification in the form of redirecting the creek through ditches or piping. Harmful channel modifications can lead to loss of channel structure, as discussed in section 7 (Klatte \& Ellis, 2002). The portion of the creek that runs through the Tryon Creek State Natural Area has a relatively more natural floodplain network but is not immune to channel structure alterations including downward incision.

\section{Data Gaps}

Connections between land use types and the hydrologic cycle should be further assessed throughout the Tryon Creek watershed. This would involve the collection of updated hydrologic data throughout stream reaches and making relationships with the nearby land use for each stream reach. Additionally, this assessment would benefit from an updated list of water rights that reflects active water use and diversion. There are private ponds and other forms of water diversion that are not recorded. Filling these gaps would provide guidance for specific restoration actions throughout the watershed.

\section{References}

City of Portland, Bureau of Environmental Services (2005). Fanno and Tryon Creeks Watershed Management Plan.

City of Portland, Bureau of Environmental Services (2009). Tryon Creek Confluence Habitat Enhancement Design Report. City of Portland Bureau of Environmental Services.

Cooper, Richard M. (2005). Estimation of Peak Discharges for Rural, Unregulated Streams in Western Oregon. U.S. Geologic Survey.

Klatte, B. \& Ellis, R. (2002). Tryon Creek Environmental Baseline Conditions and Limiting Factors Analysis for Anadromous Salmonids. West Multnomah Soil and Water Conservation District.

MacDonald, A. (2015). Hydromodification Assessment. City of Lake Oswego.

Oregon Water Resources Department (2018). Water Rights Information Query Results.

Reichle, D. (1981). Dynamic Properties of Forest Ecosystems. Chapter 4: Water relations and hydrologic cycles. Cambridge University Press.

Rhodes, J. (2002). Overview of Existing Condition, Data Gaps and Recommendations for the Protection and Restoration of Aquatic Resources. West Multnomah Soil and Water Conservation District.

Silver, B., et al. (2017). An Urban Stream Can Support A Healthy Population of Coastal Cutthroat Trout.

U.S. Climate Data (n.d.). Climate Portland - Oregon. Version 2.3.

Watershed Professionals Network (1999). Oregon Watershed Assessment Manual. Governor's Watershed Enhancement Board. Salem, Oregon.

Williams, P., et al. (1997). Phase 1 Data Review of Hydrologic and Geomorphic Conditions in the Upper Tryon Creek Watershed, 1997. Prepared for West Multnomah Soil and Water Conservation District. 


\section{RIPARIAN AND WETLANDS ASSESSMENT}

\section{Introduction}

Streams of the Western United States are often lined with linear riparian zones characterized by steep gradients and narrow floodplains. The water table of these riparian zones tends to be shallow due to proximity to the stream. High plant and animal species diversity, density, and productivity characterize the riparian ecosystems. Plant varieties include conifers, hardwoods, herbaceous flowering plants, grasses, sedges, mosses, and algae (National Riparian Service Team, 2001). Riparian and wetland habitats often overlap along the length of Tryon Creek. This connection of the features justifies the discussion of them together in this section of the watershed assessment. There are many functions that the unique riparian ecosystems provide for the aquatic environment, including shading that maintains hospitable temperatures for aquatic life. Salmonid species are among those that are sensitive to fluctuations of water temperature as well as changes in aquatic habitat. Tryon Creek is an example of a wood dependent stream, which developed within a forest and relies on the woody debris for its health (National Riparian Service Team, 2001). Large woody debris (LWD) is a term commonly used to describe woody material at least two feet in diameter, which is most hospitable as stream habitat for salmonids. There are many benefits of the presence of large woody debris in streams, including the refuge of juvenile salmon, which may spend one to several years in the stream before going to the ocean. When stream flow fluctuates during the rainy months, large woody debris contributes to a more consistent pattern for the health of the aquatic environment and its inhabitants. As the woody debris material and runoff breaks down, it also provides nutrients and energy to the aquatic food chain.

An understanding of the ecoregion conditions will help us assess the potential for large woody debris sourced from conifers. The Tryon Creek watershed is in the Willamette River ecoregion, which is a valley with elevations that range from sea level to about 400 feet and is bounded by the Coast Range to the west and the Cascade Range to the east (OPRD, 2017). Climatically, this area experiences mild, wet winters and warm, dry summers, making it hospitable to the majority of the state population and agricultural production that is found there. Besides agriculture, forested and urban are the primary land use types of this ecoregion (Pan, et al., 2001). About $75 \%$ of the precipitation occurs from October to March, which the flow magnitude of streams and rivers of the Willamette Valley is largely dependent on for stream patterns.

Wetland is a term referring to a variety of habitats that are seasonally or perennially inundated or saturated with water. They often provide a zone of transition between terrestrial and aquatic environments. Wetlands provide many hydrologic benefits including flood control, erosion and storm damage reduction, water quality maintenance, and water supply (USGS, n.d.). Even when not connected to a stream, wetlands serve to store and filter water that is part of the overall watershed (City of Portland, 2005). Wetlands tend to have water tables at or near the surface throughout the year. Persistent moisture comes from precipitation, surface runoff, flooding from the nearby stream or water body, groundwater discharge, or a combination of these sources. Wetland features are diverse throughout Oregon, yet are commonly predicted by climatic, geologic, and topographic conditions.

The Willamette River Valley is ideal for wetland formation due to the wide valley floor, climate, and geology of the region. The surrounding mountains receive large amounts of precipitation that contribute to the wetland moisture, in the form of runoff and snowmelt that enters streams and groundwater (USGS, n.d.). Drainage and flood control now present in the Willamette Valley have reduced the expanses of wetlands that once covered much of the landscape. 


\section{Riparian Conditions Assessment}

\section{Methodology}

\section{Defining Proper Functioning Condition}

A report published in 2001 detailed the application of the United States Bureau of Land Management (BLM) Riparian-Wetland Functional Checklist for assessment of the Tryon Creek watershed (National Riparian Service Team, 2001). The goal of this assessment was to determine the physical functionality of the stream's riparian zone by identifying attributes that may not be functioning as expected. By dividing the stream into segments based on common attributes and processes, the assessment applied knowledge of hydrology, soil, geology, vegetation, and biology to rate the functioning conditionality of stream reaches throughout the watershed as proper functioning condition, functional-at-risk, non-functional, or unknown (National Riparian Service Team, 2001).

\section{Streamside Resource Protection}

The City of Lake Oswego performed a vegetation protection evaluation within the city and its streams in 2018. They determined that mapped stream segments were protected if there was at least $10 \mathrm{ft}$. buffer beyond the buffer measurements described in Table 5.1 (City of Lake Oswego, 2018). Tryon Creek resource protection was quantified for the portions within the jurisdictions of the City of Lake Oswego. Riparian vegetation provides shade for streams and the City of Lake Oswego has prioritized the protection of riparian habitat as wildlife habitat as well as thermal regulation for the streams and rivers within the City.

Table 5.1 Resource Protection Overlay District Dimensions (Source: City of Lake Oswego).

\begin{tabular}{|l|l|l|}
\hline Resource Category & Buffer Measuring Point & Buffer Width \\
\hline Class I Stream & $\begin{array}{l}\text { 10 ft. outward from channel centerline, or } \\
\text { geomorphic bankfull width, whichever is } \\
\text { greater }\end{array}$ & $\begin{array}{l}\text { 30 - 50 ft. each } \\
\text { side of channel }\end{array}$ \\
\hline Class I Wetland & Delineated wetland boundary & $30 \mathrm{ft}$. \\
\hline $\begin{array}{l}\text { Class II Wetland abutting } \\
\text { Class I Stream Corridors }\end{array}$ & $\begin{array}{l}\text { 10 ft. outward from channel centerline, or } \\
\text { geomorphic bankfull width }\end{array}$ & $\begin{array}{l}25-50 \mathrm{ft} \text {. each } \\
\text { side of channel }\end{array}$ \\
\hline Class II Wetland & Delineated wetland boundary & $25-50 \mathrm{ft}$. \\
\hline $\begin{array}{l}\text { Streams and wetlands with } \\
\text { adjacent slopes }>=\mathbf{2 5 \%}(\mathbf{1 4} \\
\text { degrees) extending beyond the } \\
\text { geomorphic top of bank or } \\
\text { delineated wetlands boundary }\end{array}$ & $\begin{array}{l}\text { Slope break point between the adjacent } \\
\text { steep slope, and gentler upland areas beyond } \\
\text { the steep slope segments. Small floodplain } \\
\text { segments inset in a ravine do not constitute } \\
\text { the edge of the stream corridor. }\end{array}$ & $\begin{array}{l}\text { As described } \\
\text { above }\end{array}$ \\
\hline
\end{tabular}

Initial Vegetation Characterization of Tryon Creek State Natural Area

The Pacific Biodiversity Institute (PBI) published a vegetation inventory and mapping project in Tryon Creek State Natural Area in 2007. Although this is not a complete assessment of the riparian conditions of the entire watershed, the findings of the Pacific Biodiversity Institute will be discussed within this watershed assessment. Aerial photographs were reviewed and verified through field observations throughout the designated research zones. Plant communities of focus during field observations were those that are at-risk and invasive exotic plant species. Plant 
communities were noted when observed within the study areas. The researchers also classified the vegetation community composition for the overall condition of each polygon based on abundance of exotic plants, vegetation disturbances, and naturally occurring native plant diversity (Smith \& Morrison, 2007). Twenty-one existing vegetation communities were identified within the Tryon Creek State Natural Area, based on the application of past research. These plant community classes are listed within Table 5.2.

\section{Results}

Initial Vegetation Characterization of Tryon Creek State Natural Area

Figure 5.1 displays an image of the riparian environment of Marshall Park, which is upstream of the Tryon Creek State Natural Area. This image demonstrates the development of young and mid-growth trees and a verdant understory of ferns and mixed shrubs. Within the Tryon Creek State Natural Area, the dominant vegetation class is Fo4, which is comprised of big leaf maple (Acer macrophyllum), red alder (Alnus rubra), western red cedar (Thuja plicata), mixed shrub, English ivy (Hedera helix), and sword fern (Polystichum munitum) (table 5.2). This is indicative of a deciduous and mixed conifer forest ecology, rather than the historic old growth forest. The most common occurring trees throughout the park were big leaf maple, red alder, Douglas fir (Pseudotsuga menziesii), and young to mid-age western red cedar. While the understory was dominated by mixed shrubs, Oregon grape (Mahonia aquifolium), ferns, and English ivy. Exotic and noxious weeds were abundant throughout the park with English ivy identified as the most prolific.

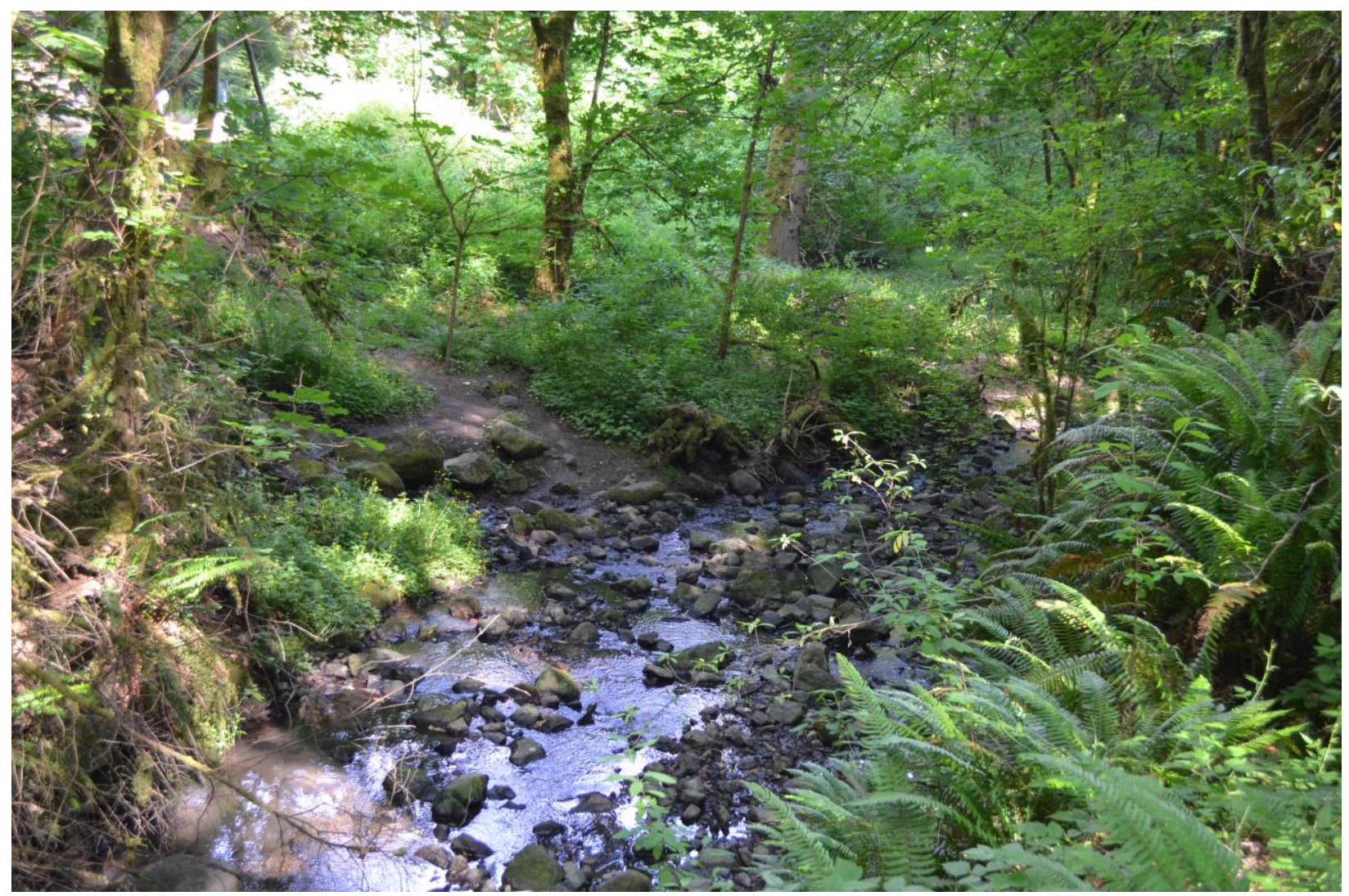

Figure 5.1 Photograph of riparian environment of Tryon Creek within Marshall Park (Source: Barton, A.). 
Table 5.2 Codes and descriptions of the vegetation communities identified within Tryon Creek State Natural Area (Source: Smith \& Morrison).

\begin{tabular}{|c|c|c|}
\hline $\begin{array}{l}\text { OPRD } \\
\text { Code }\end{array}$ & Vegetation Community Description & $\begin{array}{l}\text { Percent } \\
\text { of Area }\end{array}$ \\
\hline Fo1 & $\begin{array}{l}\text { big leaf maple - red alder - Douglas-fir / English ivy - vine maple - Himalayan } \\
\text { blackberry / sword fern }\end{array}$ & $4 \%$ \\
\hline Fo2 & $\begin{array}{l}\text { Big leaf maple - red alder - Douglas-fir / mixed shrub - dwarf Oregon grape / sword } \\
\text { fern }\end{array}$ & $5 \%$ \\
\hline Fo3 & Big leaf maple - red alder - western red cedar / mixed shrub / sword fern & $2 \%$ \\
\hline Fo4 & $\begin{array}{l}\text { Big leaf maple - red alder - western red cedar / mixed shrub - English ivy / sword } \\
\text { fern }\end{array}$ & $32 \%$ \\
\hline Fo5 & Big leaf maple - mixed conifer - red alder / mixed shrub - English ivy / sword fern & $10 \%$ \\
\hline Fo6 & $\begin{array}{l}\text { red alder - (big leaf maple - western red cedar) / salmonberry - (mixed shrub) / } \\
\text { foamflower - lady fern - (stinging nettle) }\end{array}$ & $6 \%$ \\
\hline Fo7 & $\begin{array}{l}\text { red alder - (big leaf maple - western red cedar) / salmonberry - English ivy - } \\
\text { (mixed shrub) / foamflower - lady fern - (stinging nettle) }\end{array}$ & $6 \%$ \\
\hline $\begin{array}{l}\text { Fo8 or } \\
\text { Wo8 }\end{array}$ & $\begin{array}{l}\text { red alder / Himalayan blackberry - (salmonberry - mixed shrub) / stinging nettle - } \\
\text { (canary reed grass - lady fern) }\end{array}$ & $3 \%$ \\
\hline Wo9 & $\begin{array}{l}\text { red alder / salmonberry - red elderberry / Columbia brome - creeping buttercup - } \\
\text { stinging nettle }\end{array}$ & $1 \%$ \\
\hline F10 & $\begin{array}{l}\text { Oregon ash - big leaf maple - black cottonwood / English ivy - vine maple / } \\
\text { foamflower - scouring rush horsetail - slough sedge }\end{array}$ & o\% \\
\hline F11 & $\begin{array}{l}\text { Oregon ash - big leaf maple - western red cedar / California blackberry - squash } \\
\text { berry - hardhack / foamflower - taper fruit short scale sedge - stinging nettle }\end{array}$ & o\% \\
\hline F12 & $\begin{array}{l}\text { black cottonwood - red alder - big leaf maple / mixed shrub - English ivy / sword } \\
\text { fern }\end{array}$ & $1 \%$ \\
\hline $\mathrm{F}_{13}$ & $\begin{array}{l}\text { Douglas-fir - big leaf maple - western red cedar / English ivy - dwarf Oregon grape } \\
\text { - vine maple / sword fern }\end{array}$ & $4 \%$ \\
\hline F14 & $\begin{array}{l}\text { Douglas-fir - big leaf maple - western red cedar / mixed shrub - English ivy / sword } \\
\text { fern }\end{array}$ & $13 \%$ \\
\hline F15 & $\begin{array}{l}\text { Douglas-fir - big leaf maple - western red cedar / mixed shrub - dwarf Oregon } \\
\text { grape /sword fern }\end{array}$ & $5 \%$ \\
\hline F16 & $\begin{array}{l}\text { Douglas-fir - western hemlock / vine maple - beaked hazelnut - dwarf Oregon } \\
\text { grape / sword fern }\end{array}$ & $2 \%$ \\
\hline $\mathrm{F} 17$ & $\begin{array}{l}\text { western red cedar - big leaf maple - red alder / mixed shrub - English ivy - } \\
\text { (Himalayan blackberry) / sword fern }\end{array}$ & $2 \%$ \\
\hline F18 & $\begin{array}{l}\text { western red cedar - red alder - big leaf maple / salmonberry - (English ivy) / lady } \\
\text { fern - stinging nettle - foamflower }\end{array}$ & o\% \\
\hline So1 & Sitka willow - English ivy - Himalayan blackberry & $\mathrm{o} \%$ \\
\hline So2 & $\begin{array}{l}\text { English hawthorn / English ivy - salmonberry - English holly / sword fern - } \\
\text { Kentucky bluegrass }\end{array}$ & $1 \%$ \\
\hline $\begin{array}{l}\text { Vo1 or } \\
\text { Do1 }\end{array}$ & Developed or disturbed & $3 \%$ \\
\hline
\end{tabular}

\section{Defining Proper Functioning Condition (PFC)}

The PFC of Tryon Creek was assessed for sections of the watershed, divided into seven reaches, which are listed in table 5.3. At the time of this evaluation in 2001, there were no PFC reaches established in the upper watershed urban area tributaries, yet it was assessed through observation (National Riparian Service Team, 2001). Consequences of urbanization are apparent in 
the redirection of Tryon Creek through stream-like drainage ditches in some sections as well as development of homes and street construction in the floodplain. An observation of highly developed areas of the watershed was that storm drains flowed directly into the creek from houses, streets, and parking lots. The storm drains are noted to accelerate water flow and carry pollutants into the aquatic habitat. Many streams of the Tryon Creek headwaters have been altered functionally from the historic stream channel and processes that existed before the development that is present today.

Table 5.3 Tryon Creek Stream Reach PFC Determinations (Source: West Multnomah Soil and Water Conservation District).

\begin{tabular}{|l|l|l|}
\hline Reach & \multicolumn{1}{|c|}{ Stream Name } & \multicolumn{1}{c|}{ PFC Determination } \\
\hline $\mathbf{1}$ & Tryon Creek mainstem at the confluence & Nonfunctional \\
\hline $\mathbf{2}$ & Tryon Creek mainstem & Proper Functioning Condition \\
\hline 3 & Tryon Creek mainstem & Functional-at-risk \\
\hline 4 & Tryon Creek mainstem & Functional-at-risk \\
\hline 5 & Tryon Creek mainstem & Functional-at-risk \\
\hline 6 & Arnold Creek & Nonfunctional \\
\hline 7 & Iron Mountain Creek & Proper Functioning Condition \\
\hline
\end{tabular}

The next section that was assessed includes the major tributaries of Tryon Creek (reaches 5, 6, and 7), which have been subjected to down-cutting due to timber harvest and road construction. Although the geology and clay soil structure of some of these tributaries, including Arnold Creek, provide channel stability, much of the floodplain has been degraded with the loss of large trees. Tributaries that may still have floodplains intact suffer from a loss of large woody debris and therefore are subject to sediment transport and stream widening. Falling Creek was observed to have poor riparian integrity with high occurrence of channel diversion and development near the stream (City of Portland, 2005). One section that appears to show early signs of PFC is Iron Mountain Creek with a small floodplain and enough large woody debris in the area to slow runoff and stream flow and store sediments. Newly planted trees including western red cedars show opportunity for large woody debris in the future yet are threatened by the presence of Himalayan blackberry and English ivy (National Riparian Service Team, 2001). Tributaries provide refuge for wildlife as well as water storage in the floodplain during storm events (Tappenbeck \& Vaivoda, 200o). Although there is a high impact of developed land in this section of the watershed, the riparian environment is concluded to be maintaining functional processes with the current pressures.

The Tryon Creek Alluvial Valley (reaches 3, 4, and 5) is located within the Tryon Creek State Natural Area and is noted to have depositions of deep soils and presence of LWD despite extensive historic logging. Due to lack of sufficient large woody debris following logging events, the stream has incised in sections and lost connection with the floodplain. Riparian vegetation is most functional in this section with a high presence of deciduous trees and mixed conifers (Tappenbeck \& Vaivoda, 2000) with small patches of vegetative diversity (Smith and Morrison, 2007). The stream extends to the floodplain and therefore has a dynamic pattern of flow with pools, areas for water storage, and presence of steep banks. At the time of the survey, a beaver dam was present and acting as sediment and water storage (National Riparian Service Team, 2001).

The Lower Transport Reach (reaches 1 and 2) is characterized as a confluence section that transports sediments along stream bottom and banks composed primarily of bedrock. The primary land use of this section is industrial and urban residential, with a sewage treatment plant to the south of the creek (Tappenbeck \& Vaivoda, 2000). The stream substrate is composed of fine 
sediments, gravel, and cobble with a low concentration of LWD. At the confluence, tree cover is minimal with grasses and vines as the dominant vegetation (City of Portland, 2005). Throughout this section, the bedrock walls are steep and narrow (National Riparian Service Team, 2001), which concentrates stream energy that defines wood and sediment travel.

\section{Streamside Resource Protection}

Through the evaluation of resource protection, it was concluded that $93.5 \%$ of the Tryon Creek watershed within the City of Lake Oswego was protected $10 \mathrm{ft}$. past the stream buffers (City of Lake Oswego, 2018). Protection is provided by the City of Lake Oswego, Oregon Parks and Recreation, City of Portland, and other jurisdictions. It was estimated that over 200 acres of stream buffers of Tryon Creek are protected by resource protection districts that aim to reduce disturbance and increase riparian habitat (City of Lake Oswego, 2018).

\section{Wetland Assessment}

\section{Methodology}

Potential Wetlands

Wetlands are described as areas that are inundated or saturated by water for all or part of the year (Roth, et al., 1996). Wetlands serve as transitional phases for vegetation and soils between stream networks and the terrestrial surroundings. There is often a high variety of plant and animal species in the wetland zones of ecosystems. Wetland identification aids in the understanding of location and extent of potential wetlands within a watershed through the analysis of soil classifications, channel habitat types, National Wetland Inventory (NWI) maps, and USGS maps.

The United States Fish and Wildlife Service (USFWS) has compiled spatial data of surface waters and wetlands into a National Wetland Inventory (NWI). The NWI is intended to be a tool for the understanding of wetland and hydrology activity within the United States (USFWS, 2019). Records of wetlands and surface waters for each HUC8 watershed were recorded and represented as polygon features. Aerial imagery and hydrography data were reviewed for this assessment. For the purposes of this study, wetlands are defined by Cowardin et al. (1979) as "lands transitional between terrestrial and aquatic systems where the water table is usually at or near the surface or the land is covered by shallow water. For purposes of this classification wetlands must have one or more of the following three attributes: (1) at least periodically, the land supports predominantly hydrophytes;' (2) the substrate is predominantly undrained hydric soil;2 and (3) the substrate is non-soil and is saturated with water or covered by shallow water at some time during the growing season of each year."

\section{Results}

\section{Potential Wetlands}

Wetlands of the Tryon Creek watershed are characterized by the National Wetland Inventory as freshwater forested/shrub wetlands and are total to about 14.5 acres with about 70 acres of riverine wetland at the time of the survey (NWI, 2019). All of the wetland habitats displayed in figure 5.2 are located along the stream system (Natural Resource Management Group, 2002). Forest and shrub wetlands, as observed in Tryon Creek are categories of palustrine wetland habitats. Riverine systems include water bodies that are "contained within a channel" that are often rivers or streams (Cowardin, et al., 1979). In this case, the stream network of Tryon Creek is largely characterized as a riverine wetland system with flowing water. Sections that are not included would 
be the palustrine systems and water that has been diverted underground. Palustrine systems are defined by the vegetation that contains them, in this case that is forest and shrub species. 


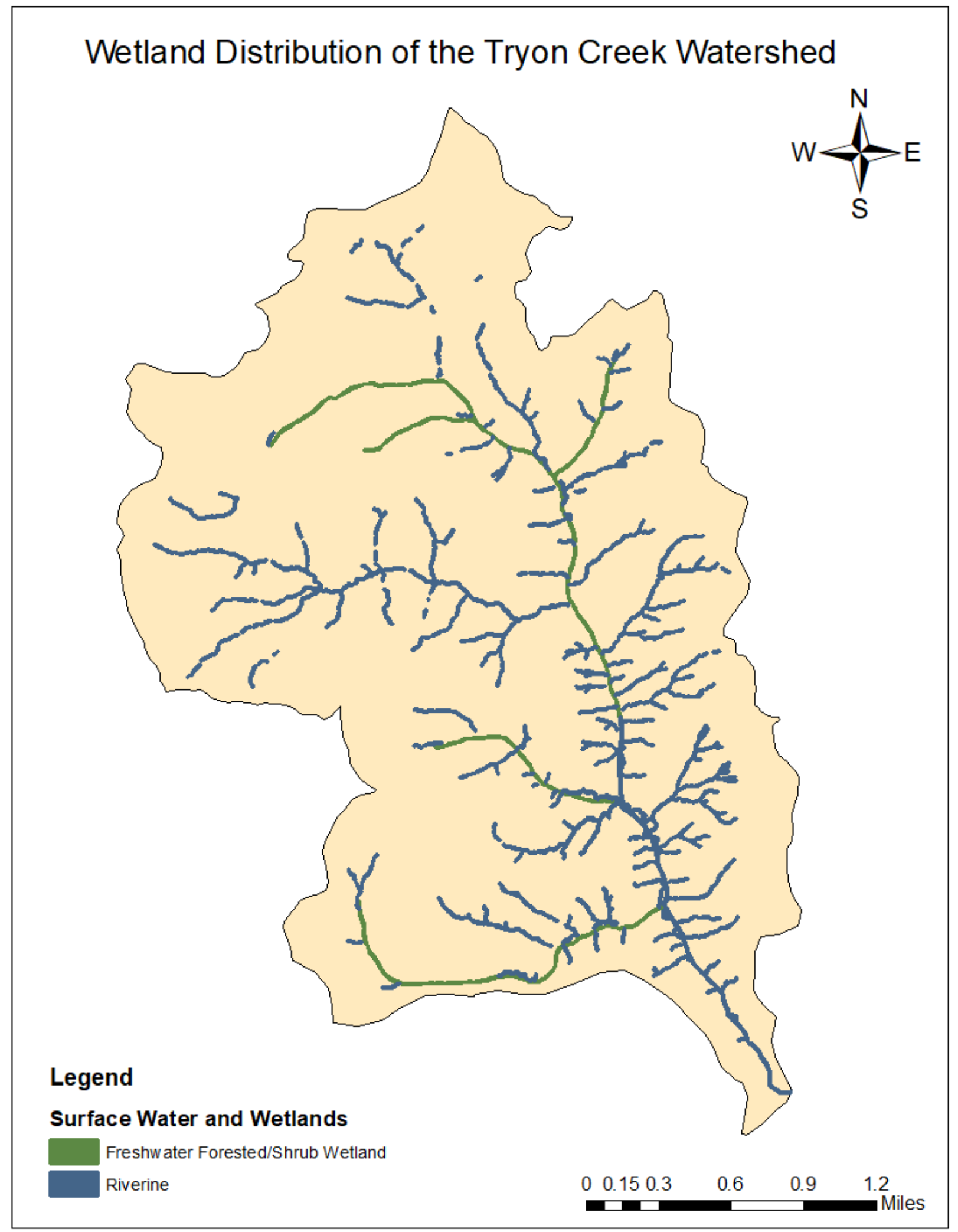

Figure 5.2: Map of the riverine and palustrine wetlands of the Tryon Creek watershed (Sources: Tryon Creek Watershed, National Wetland Inventory). 


\section{Conclusions}

The role that riparian zones play for a forested stream system and its wildlife are numerous. A high diversity of wildlife and plant communities depend on riparian zones for habitat and refuge. Additionally, vegetation provide shading and LWD that benefit the water quality and habitat of a stream. The tree canopy throughout riparian habitats of the watershed are primarily dominated by Douglas fir, big leaf maple, western hemlock, western red cedar, grand fir, red alder, and black cottonwood (Portland Parks and Recreation, 2009). The understory vegetation includes vine maple, sword fern, oso berry, Oregon grape, and salmonberry. The functionality of the riparian zones throughout the watershed varies from nonfunctional to proper functioning condition (National Riparian Service Team, 2001).

There are many factors that may reduce potential for riparian vegetation, some of which in the Tryon Creek watershed are historic logging and urbanization (Rhodes, 2002). Urbanization include construction of roads and house development along the stream. The effects of urbanization that riparian zones can help to minimize are sediment loading as well as elevated peak flows. Vegetation provides bank stability and reduces influence of sediments and pollutants within a stream. Additionally, trees provide large woody debris, which provides desirable fish habitat and reduces stream flow, therefore decreasing erosion and detaining sediment. Development encroachment, especially in the upper portions of Tryon Creek, results in erosion, bank failure, and loss of natural vegetation (City of Portland, 2005). Increasing water temperature, channel erosion and incision, and loss of bank stability are responses to poor riparian habitat in the Tryon Creek watershed.

Wetlands provide habitat for terrestrial wildlife as well as store and slow water release into streams and groundwater. For that reason, wetlands without surface connections to streams contribute to the watershed hydrology (City of Portland, 2005). The terrain of the Tryon Creek watershed has a high proportion of steep gradient, which decreases opportunity for formation of functional wetlands. Most of the sections that are characterized as wetlands are within the Tryon Creek State Natural Area where the creek can more naturally meander through protected vegetation. With an understanding of the palustrine and riverine wetlands characteristics and needs, managers can focus efforts on maintaining the natural environment of the stream system, including its associated wetlands.

Habitat restoration and protection is an effective tactic for improving the function of the riparian zone. It is suggested that land managers plant native vegetation, including conifers that restore LWD sources in the long-term (City of Portland, 2005). Continuation of invasive species removal will provide resources to aid in the success of native species that can stabilize banks more efficiently. Riparian integrity is noted to decrease with increased encroachment of land use, therefore alleviation of the effects of urbanization should be a priority.

\section{Data Gaps}

The most identifiable data gap is the lack of recent riparian and wetland assessments. A majority of the research reported may not represent the current state of the watershed. Therefore, it would be helpful to collect data to gain an understanding of the current state of the riparian zones as well as planned stewardship efforts. It would be suggested to build upon the methodology applied in previous assessments in order to capture a comparison of field observations. Additionally, it would be suggested to gather data regarding riparian habitat and wetland presence with more specificity in order to target efforts to location within the stream reaches. 


\section{References}

Barton, A. (2019). Photograph of riparian environment of Tryon Creek within Marshall Park. Tryon Creek Watershed Council.

City of Lake Oswego (2018). TMDL Implementation Plan 2019-2023.

City of Portland, Bureau of Environmental Services (2005). Fanno and Tryon Creeks Watershed Management Plan.

Cowardin, L., et al. (1979). Classification of Wetlands and Deepwater Habitats of the United States. United States Fish and Wildlife Service.

National Riparian Service Team (2001). Tryon Creek PFC Assessment. West Multnomah Soil and Water Conservation District.

Natural Resource Management Group (2002). Tryon Creek Watershed Hydrogeologic Assessment. West Multnomah Soil and Water Conservation District.

OPRD (2017). Natural Resource Assessment and Strategic Action Plan- Willamette Basin.

Pan, Y., et al. (2001). Bioassessment of Urban Streams (Johnson Creek and Tryon Creek). Portland State University Environmental Sciences and Resources.

Rhodes, J. (2002). Overview of Existing Condition, Data Gaps and Recommendations for the Protection and Restoration of Aquatic Resources. West Multnomah Soil and Water Conservation District.

Roth, E., et al. (1996). Oregon Freshwater Wetland Assessment Methodology. Oregon Division of State Lands.

Smith, H. IV \& Morrison, P. (2007). Vegetation Inventory and Mapping of Tryon Creek State Natural Area. Pacific Biodiversity Institute, Winthrop, Washington.

Tappenbeck, T \& Vaivoda, A. (2000). ODFW Aquatic Inventory Project: Tryon Creek \& Arnold Creek Habitat Report Summaries. City of Portland.

USFWS. National Wetland Inventory. Version 2.

USGS. National Water Summary- Wetland Resources: Oregon. 


\section{SEDIMENT SOURCES ASSESSMENT}

\section{Introduction}

This sediment sources assessment is focused on classification of instream sediment loads and sources of those sediments. Natural sources of sediments originate from the breakdown of rocks by precipitation and erosion. Sediments are carried overland by water. Human activities such as construction and maintenance also provide sources of sediments. Once in the stream system, sediments are transported further downstream or deposited on the stream bed (City of Lake Oswego, 2015). Due to high channel slope and low roughness, sediment transported downstream in this watershed is often dropped from the flow at the confluence of Tryon Creek and the Willamette River (Herrera Environmental Consultants, 2009). If sediment has not made it that far, it deposits on the stream bed, altering the functionality of the aquatic ecosystem. Sediments of varying sizes can be derived from hillslopes, yet the majority originate from erosion of stream banks and even the stream bed (Herrera Environmental Consultants, 2009). In this assessment, fine sediment is used to describe rock material characterized as silt or clay, which measure less than $0.06 \mathrm{~mm}$. Gravel (>0.6 mm) and sand (0.06-0.6 mm) would be examples of larger sediments that can be beneficial for aquatic habitat because they provide resources such as refuge and food through algae growth (Haritashya et al., 2010).

Sediment deposition overlying the volcanic rocks of the area are from multiple major periods. Columbia River Basalts derived from the Cascades and the Boring volcanoes provided coarser sediment materials (City of Lake Oswego, 2015). The largest depositional source was the series of Missoula Floods that left behind layers of fine sediments between 16,000 and 12,000 years ago.

According to the USGS Soil Survey Manual for Multnomah County, the predominant soil classification in the Tryon Creek watershed is the Cascade series (City of Portland, 2005). The Cascade series is a poorly draining soil that can be moderately deep and consisting of silty loam. The fragipan layer is typically 20 to 30 inches below the surface level and ranges from about two to four feet thick. This layer is composed of fine sands that, similar to clay, form a cemented layer that acts to prevent root formation and infiltration. This contributes to intensity of erosion during precipitation events. During the dry summer months, the soil can act as an impervious surface because it dries about 4 to 12 inches below the surface (City of Portland, 2005). During wetter months, the water table usually perches on the fragipan layer.

The Tryon Creek watershed and its surrounding area are composed of steep slopes, resulting in a high frequency of landslides (City of Lake Oswego, 2015). Based on slope, almost all of the watershed is considered to be areas of potential landslide hazard. There are historic records indicating landslide occurrence in the area, yet more frequent development in recent decades likely makes the land more susceptible to sliding. Human development increases rates of erosion largely due to increased impervious surfaces, especially on hilly terrain, steep ridges, and ravines (City of Lake Oswego, 2013). In 2005, the City of Portland estimated that $24 \%$ of the total watershed was covered in impervious surfaces such as roads, parking lots, and buildings (Table 6.1). 
Table 6.1 Percentage of impervious surfaces covering three of the sub-watersheds of the Tryon Creek watershed. (Source: City of Portland).

\begin{tabular}{|l|l|l|l|}
\hline \multicolumn{1}{|c|}{ Sub-watershed } & \multicolumn{1}{|c|}{$\begin{array}{c}\text { Impervious } \\
\text { Surfaces (Acres) }\end{array}$} & $\begin{array}{c}\text { Sub-watershed } \\
\text { Total Area (Acres) }\end{array}$ & $\begin{array}{c}\text { Percentage of } \\
\text { Sub-watershed }\end{array}$ \\
\hline $\begin{array}{l}\text { Tryon Creek Mainstem } \\
\text { (including TCSNA) }\end{array}$ & 696.1 & $3,083.7$ & 22.6 \\
\hline Arnold Creek & 192.9 & 775.2 & 24.9 \\
\hline Falling Creek & 105.9 & 283.6 & 37.3 \\
\hline Total (Watershed) & 994.9 & $4,142.3$ & 24.0 \\
\hline
\end{tabular}

Runoff flow rates are also increased by urbanization due to impervious surfaces that inhibit stormwater runoff absorption into soils of the watershed. Consequently, lag time, or the time for stream flows to peak after a storm event, is also shortened. Contrary to a natural watershed system, rainwater that falls on an urban environment has less opportunity to infiltrate and store in the soil, but rather flows directly to the stream bed carrying suspended pollutants and sediments (Williams \& Coulton, 1997). Sediment deposition associated with development is highest during construction and remains higher than a natural environment afterwards (Rhodes, 2002). A USGS study conducted in 1980 found that a completely urbanized basin in the Portland region could experience a tripled peak discharge and doubled storm runoff volume compared to a natural basin (Williams \& Coulton, 1997).

The stormwater runoff that is collected and conveyed through the Municipal Separate Storm Sewer System (MS4) is typically discharged to the natural stream system. Streets and the street drainage systems have replaced the small natural drainage channels that preceded urbanization at many locations. Therefore, the street drainage system both manages the stormwater runoff generated from street areas and also serves as a link in the overall drainage system conveying runoff generated from adjacent properties back to the natural stream system (City of Portland, 2005). Overall, 27\% of the storm drainage system in these watersheds remains part of the natural stream system with the remaining $73 \%$ replaced by the MS4 system. The result of a high dependency on urban stormwater drainage systems results in an increase in rate of flow to the stream; meaning shorter time for overland flow, higher stream velocities, and more drastic storm responses.

Higher rates of water flow cause more sediment erosion and subsequent stream deposition. Although gravel and other large rocks provide beneficial habitat for aquatic organisms, there are many deleterious consequences of fine sediment deposition. A 1980 study on the effects of urbanization on hydrology found a negative relationship between impervious surfaces and the health of aquatic organisms (Williams \& Coulton, 1997). Biotic integrity (the condition of macroinvertebrates) and salmonid integrity (Coho/cutthroat ratio) were higher in undeveloped watershed with $5 \%$ or less imperviousness while they decreased as urbanization increased. In 2005 , it was estimated that about $85 \%$ of riffle habitat downstream of Boones Ferry Road has become marginal or undesirable due to fine sediments (City of Portland, 2005). It has been reported that macroinvertebrates that are tolerant to high levels of sediment are present throughout the watershed (Rhodes, 2002). High concentrations of fine sediment limit the biological productivity of a stream habitat. Sediment coats bed rock and reduces interstitial spaces that provide habitat for aquatic invertebrates, the food for native fish. Sediment can also smother the algal food source for aquatic invertebrates on rocks, as well as salmon redds or even fry (Rhodes, 2002). Once reaching adulthood, fish can be susceptible to the sediment clogging of fish gills and even thickening of the gill epithelium, through which oxygen is absorbed. Reduced visual capability is also a result of sediment loads and can lead to decrease in feeding success. Other issues associated with aquatic 
organism exposure to suspended sediments are physiological stress and decreased tolerance to disease.

Tryon Creek State Natural Area and the surrounding forest are characterized by a steep ravine landscape. Basalt flows have traveled throughout the watershed resulting in a landscape composed of approximately 60 to 75 percent of the slopes exceeding a 30 percent grade (City of Portland, 2009). Sediments are easily transported by the waters that fill the steep and confined channels of Tryon Creek. Historic flows are a major source of natural sediments that impact the watershed. The bedrock resulting from the Columbia River Basalt Group (CRBG) can be seen exposed along various portions of the upper channel of Tryon Creek and the lower portion of the Tryon Creek State Natural Area. This basalt lava flowed over northern Oregon and southwest Washington between 14 and 17 million years ago (City of Portland, 2009). The upper part of the state natural area is composed of an older section of basalts and sedimentary rocks titled the Basalts of Waverly Heights aging back 35 to 55 million years. More recently (about 1 million years ago), the Boring Lavas covered the CRBG in the western portion of the watershed with a basaltic and andesitic composition, originating from Mt. Sylvania (Williams \& Coulton, 1997). The Boring lavas are characterized by a locally perched water table. Fine-grained sediments from the Missoula Floods can be found in the Multnomah and Capitol Hill area. The basaltic bedrock is more compacted and not eroded as much as sedimentary rocks, leading to less sediment sources within the creek where basalt is dominant. Figure 6.1 shows a section of exposed basalt bedrock in Marshall Park. This portion of the creek is characterized by steep slopes that cause transport of sediment and erosion, leading to exposure of the underlying bedrock. The basalt-sourced sediment can be characterized as angular in shape, causing it to have more potential for sediments to settle in cavities among the rocks (Herrera Environmental Consultants, 2009). An angular characteristic is also a sign of less erosion and therefore indicative that flow velocity is lower through those reaches. 


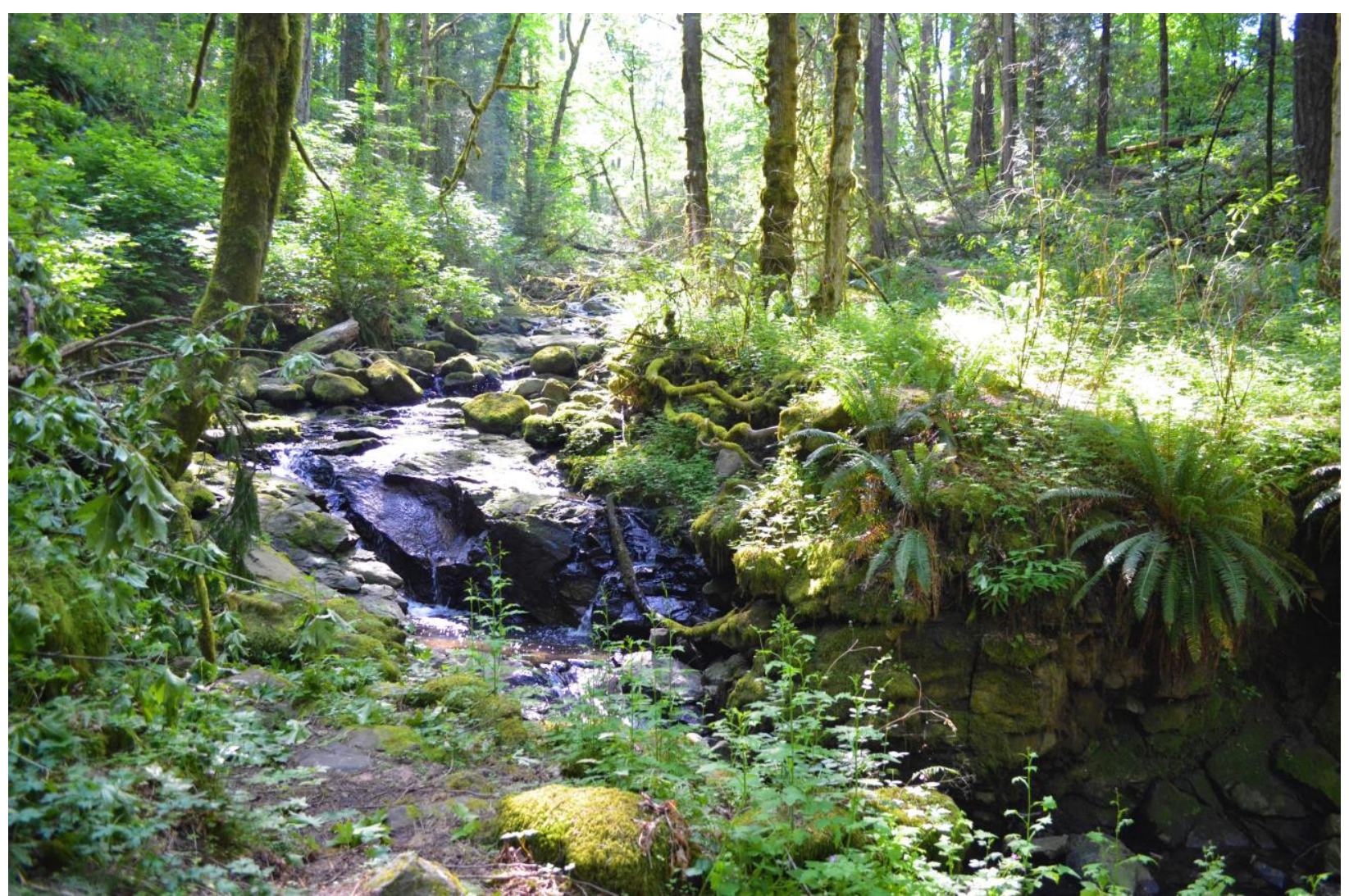

Figure 6.1 Image of the exposed bedrock of Tryon Creek within Marshall Park (Source: Barton, A.)

\section{Methodology}

\section{Street Drainage Characterization and Identification of Sediment Sources}

The City of Portland prepared an overview of the street drainage systems of Tryon Creek within the City of Portland including a characterization of the street drainage types and identification of fine sediment sources. It has been found that street type affects stormwater patterns, mainly the way that water travels along the surface and is diverted away. To better understand these stormwater patterns, it was prioritized to determine the street drainage systems throughout the watershed (City of Portland, 2012). Figure 6.2 provides a representation of the roads and highways throughout the Tryon Creek watershed. This map illuminates the pattern of impervious surfaces. The majority of the impervious surfaces are roads and buildings with possibly the most impactful being the Interstate 5 freeway that crosses the upper portion of the Tryon Creek watershed. Assessing street type distributions will illuminate more about fine sediments sourced from impervious surfaces and prioritize streets to improve to decrease impacts on the stream ecology. The four categories of street drainage systems based on level of street improvement are as follows:

1. Curbed - These streets are composed of a hard surface, usually asphalt, and are bordered with curbs. Storm drainage infrastructure is common because the curbed area controls drainage.

2. Uncurbed - These streets are made of hard surfaces, usually asphalt, without any curbs. Roadside ditches and dispersal over the surface onto adjacent properties are the predominant form of street drainage. 
3. Unimproved - These streets are not developed to City Standards and can be made from hard surfaces (asphalt or oiled gravel), gravel, or bare earth. Street drainage infrastructure is likely not developed, causing drainage to rely on ditches, undefined flows, or eroded channels in the roadway.

4. Non-existing - These streets are planned yet are not improved nor used for vehicle traffic. 


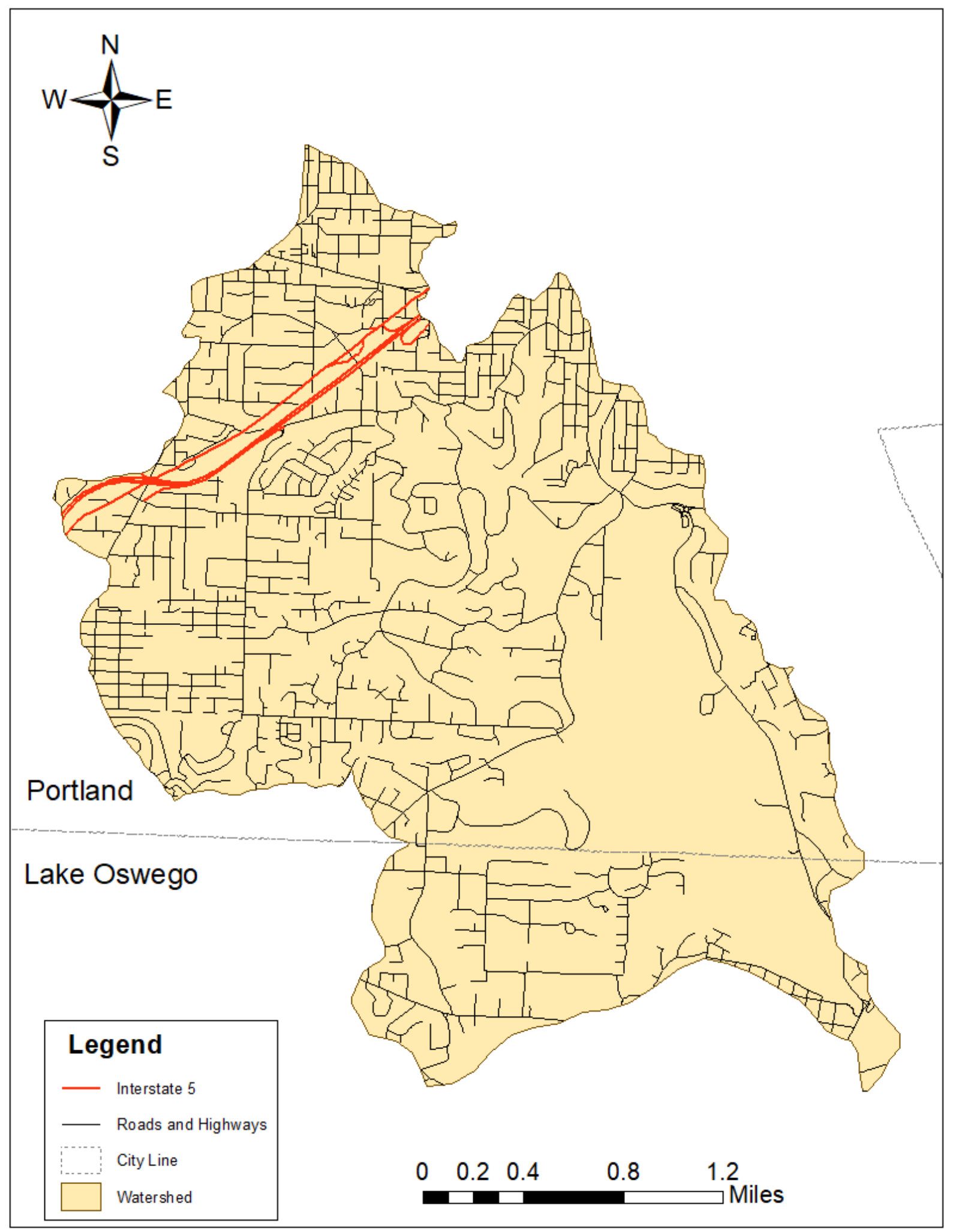

Figure 6.2 Map of roads and highways in the Tryon Creek watershed (Sources: Tryon Creek Watershed Council, Oregon Department of Transportation). 
After identifying street drainage types, researchers evaluated where stormwater went after running off buildings and roads. This involves a study of the collection and conveyance of stormwater runoff which includes curbside flow, storm sewer pipes, roadside ditches, piped outfalls to streams, or undefined flow discharged to land adjacent to streets. Within these watersheds, storm drainage was constructed with development as needed, therefore varies greatly in terms of age, materials, and methods of construction, and current condition. Many stormwater drainage systems are constructed in response to street type, making it important to study the two together when learning about stormwater and sediment sources. Private property sourced stormwater runoff typically directs to the street due to topography, soil conditions, and lack of other options. Therefore, this study focused on publicly owned drainage systems for the project and used existing data to learn about drainage patterns. It should be noted that maintenance of private drainage systems is the responsibility of adjacent property owners rather than the city.

The next step of the assessment was to sample stormwater runoff in December 2010 and January 2011- 6 at curbed streets, 7 at uncurbed streets, and 7 at unimproved streets. The parameter initially measured in the field was turbidity (City of Portland, 2012). Total Suspended Solid (TSS) concentrations were estimated using these samples as well as previous TSS and turbidity measurements gathered from other streams around the Portland area.

\section{Confluence Sediment Characterization}

The Tryon Creek Confluence Habitat Enhancement project is a multi-agency effort led by the City of Portland to improve fish habitat and passage between the Hwy 43 culvert and the confluence of Tryon Creek. In August 2008, Phase I of this project, improvement of habitat at the Hwy 43 culvert, was completed. In support of Phase II, a geomorphic assessment near the culvert took place and this included a sediment characterization of three study sites (Herrera Environmental Consultants, 2009). Surface pebble counts and observations of depositional patterns were used to learn about the instream sediment character of the project reach. Using a gravelometer, which measures the width of a pebble by the hole in the instrument that it fits through, sample sediment was categorized along transects within the study site (Herrera Environmental Consultants, 2009). Grain size distribution was separated into four categories for each study site of the assessment, based on the Wolman pebble count. The four categories are determined using percentile of samples finer than the median grain size of 100 samples taken using a transect method (Wolman, 1954) (Table 6.2).

Table 6.2 Grain sizes for a range of percentiles describing the particle size distribution at the three sites in Tryon Creek (Source: City of Portland).

\begin{tabular}{|l|l|l|l|}
\hline \multirow{2}{*}{ Percentile } & \multicolumn{3}{|c|}{ Grain size $(\mathrm{mm})$} \\
\cline { 2 - 4 } & \multicolumn{1}{|c|}{ Site 1 } & \multicolumn{1}{|c|}{ Site 2 } & \multicolumn{1}{|c|}{ Site 3 } \\
\hline $\mathrm{D}_{16}$ & 32.1 & 12.1 & 7.2 \\
\hline $\mathrm{D}_{5 \mathrm{o}}$ & 69.5 & 39.4 & 12.7 \\
\hline $\mathrm{D}_{84}$ & 120.5 & 80.7 & 21.9 \\
\hline $\mathrm{D}_{9 \mathrm{o}}$ & 146 & 92.6 & 25.2 \\
\hline
\end{tabular}




\section{Results}

Street Drainage Characterization and Identification of Sediment Sources

Assessment of street drainage in the sections of Fanno and Tryon Creek watersheds within Portland found that $72 \%$ of the streets are maintained by Portland Bureau of Transportation (PBOT), $26 \%$ are privately maintained, and $2 \%$ are maintained by other agencies including Oregon Department of Transportation (ODOT) and Multnomah County. City maintained streets were divided as $42 \%$ curbed, $49 \%$ uncurbed, and $9 \%$ unimproved while private streets were primarily uncurbed (37\%), unimproved (26\%), and non-existing (31\%) with only 6\% curbed (Table 6.3). Figure 6.3 displays a map of the street types of Fanno and Tryon Creek watersheds within the City of Portland.

Table 6.3 Street type distribution among agency within Fanno and Tryon Creek watersheds (Source: City of Portland).

\begin{tabular}{|c|c|c|c|c|c|}
\hline \multirow{2}{*}{$\begin{array}{l}\text { Maintenance } \\
\text { Responsibility }\end{array}$} & \multicolumn{4}{|c|}{ Length of Each Street Type (ft.) } & \multirow{2}{*}{$\begin{array}{c}\text { Total } \\
\text { Length }(\mathrm{ft} .)\end{array}$} \\
\hline & Curbed & Uncurbed & Unimproved & Non-existing & \\
\hline $\begin{array}{l}\text { City of Portland } \\
\text { (PBOT) }\end{array}$ & 381,022 & 386,028 & o & o & 767,051 \\
\hline Private & 18,206 & 103,824 & 75,223 & 88,557 & 285,810 \\
\hline ODOT & 14,355 & 664 & o & $\mathrm{O}$ & 15,019 \\
\hline $\begin{array}{l}\text { Multnomah } \\
\text { County }\end{array}$ & o & 8,490 & 488 & 5,623 & 14,601 \\
\hline Totals & 413,584 & 499,007 & 75,711 & 94,180 & $1,082,481$ \\
\hline
\end{tabular}


$\left.\right|_{S} ^{N}$

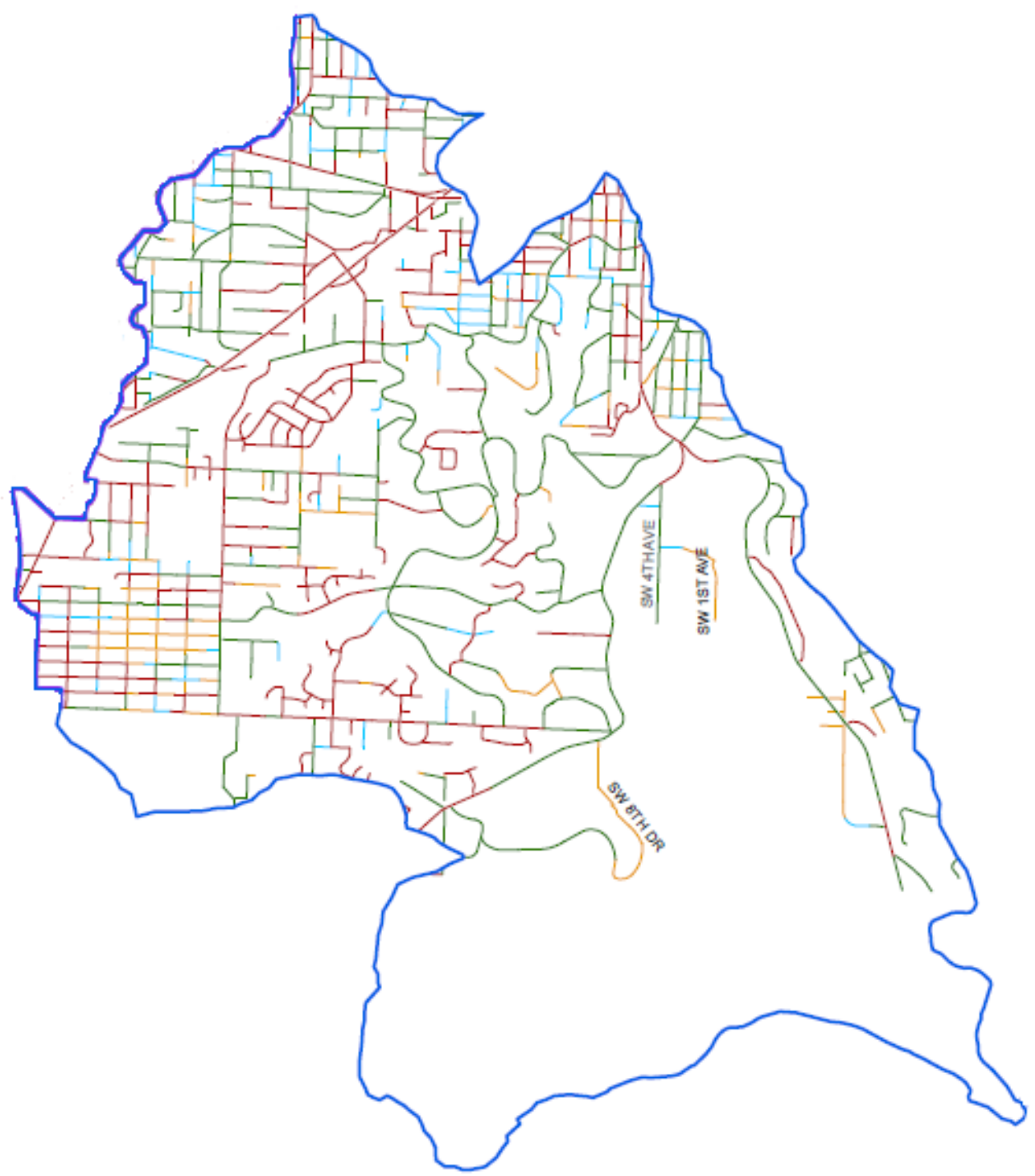

\section{Legend}

- Uncurbed, unimproved surface non-existing

- Uncurbed and unimproved surface

- Uncurbed and asphalt, concrete, or oiled gravel

- Curbed and asphalt, concrete, or oiled gravel

$\begin{array}{lllll}0 & 0.2 & 0.4 & 0.8 & 1.2\end{array}$

Miles

Figure 6.3 Map of street types within the City of Portland in the Tryon Creek watershed (Source: City of Portland). 
With a better understanding of the street drainage types, the storm drainage systems of Fanno and Tryon Creek watersheds were assessed. The City's MS4 represents the publicly owned components of the street drainage system, which is made of $62 \%$ pipes, $30 \%$ ditches, and $8 \%$ culverts. The Fanno and Tryon Creek watersheds contain 690 individual MS 4 drainage basins across 5,413 acres. With $75 \%$ of the MS4 basins less than 10 acres, they are generally small in size due to topography and the geographic location of these watersheds. The relatively small size of the drainage basins means that management also occurs on a small scale and is dependent on local drainage patterns such as conveyance capacity, rerouting and discharge of storm flows, and erosion.

Finally, this research assessed the sources of fine sediments in Fanno and Tryon Creeks. Turbidity measurements of stormwater from curbed, uncurbed, and unimproved streets suggest that turbidity decreases as road infrastructure improves. Turbidity at curbed streets was the lowest and least variable with a mean value of 10 NTUs (Figure 6.4). Turbidity values were more varied at uncurbed and unimproved streets, causing researchers to display the median value of 28 NTUs for uncurbed and 180 NTUs for unimproved streets.

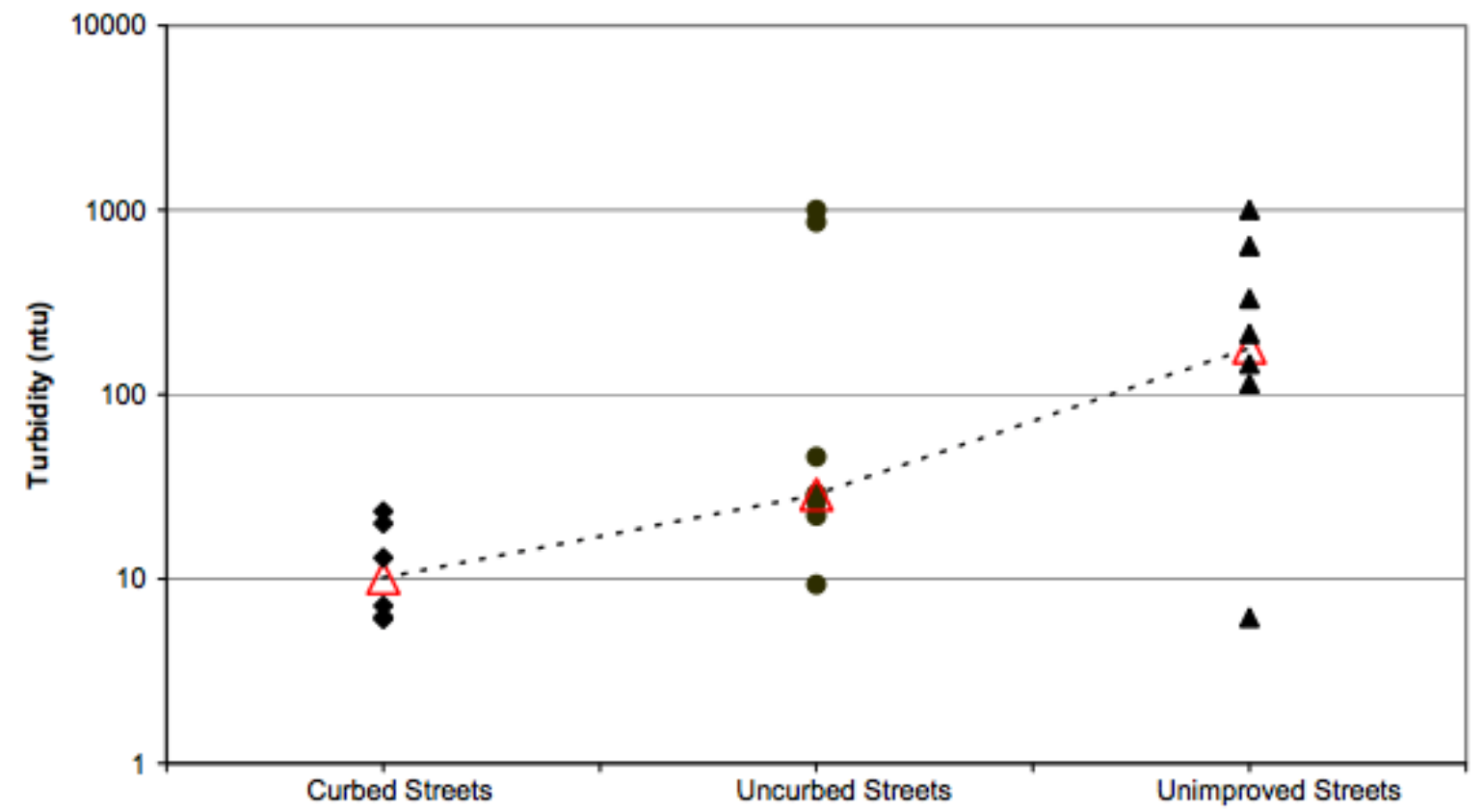

Figure 6.4 Turbidity measurements at each of the sampled locations with the median values indicated using red triangles (Source: City of Portland).

The median turbidity values and the PAWMAP data correlations were used to estimate the corresponding TSS concentrations. The estimated values are $20 \mathrm{mg} / \mathrm{l}$ for curbed streets, $56 \mathrm{mg} / \mathrm{l}$ for uncurbed streets, and $360 \mathrm{mg} / \mathrm{l}$ for unimproved streets. Using these values and the percentages of each street type throughout the watersheds, stormwater runoff TSS was calculated for each of the watersheds. Within the Tryon Creek watershed, estimated fine sediment loading for the street types were $12 \%$ from curbed, $41 \%$ from uncurbed, and $46 \%$ from unimproved. Although unimproved streets represent $9 \%$ of the watershed's infrastructure, they contribute almost half of the sediment loading. This is a concern because these streets are not city maintained. 


\section{Confluence Sediment Characterization}

This study aimed to assess sediment distribution at three sites near the Hwy 43 culvert in order to study the effects of the culvert on sediment distribution. Another goal of the study was to learn about the impact of bedrock size and structure on sediment distribution. Pebble Count Site 1 was located on a natural riffle downstream of a 48 -inch stormwater outfall pipe (Herrera Environmental Consultants, 2009). The survey found that the sediment was composed of large angular material fixed into place together and a layer of mobile material on top. This distribution was concluded to be maintained by the riffle feature. Pebble Count Site 2 was located upstream of Hwy 43 on a mid-channel bar downstream of a log lodged across the streamflow. The bar feature indicates mobile, yet stable material (Herrera Environmental Consultants, 2009). The rocks were mostly angular, basaltic.

Pebble Count Site 3 was also on a gravel bar upstream of Hwy 43, while downstream of a bedrock step and utility crossing. Contrary to site 2 , this site was made of smaller sediment that seemed to have recently distributed to this location. The bar was made of rounded rocks at a lower density than site 2. It is concluded that the variation between the bar features at sites 2 and 3 indicate multiple phases of sediment transport. The sediment at site 3 represents a phase of less dense, more rounded sediment carried by lower rates of flow and more often while the larger, denser, and more angular sediments require a faster flow to mobilize. These two categories of sediments are likely more separated at distinct features of deposition after storm conditions. Finally, a third category of sand and finer particles is likely transported downstream often. Figure 6.5 displays the distribution of particle size as they compare to the median size at each of the three study sites.

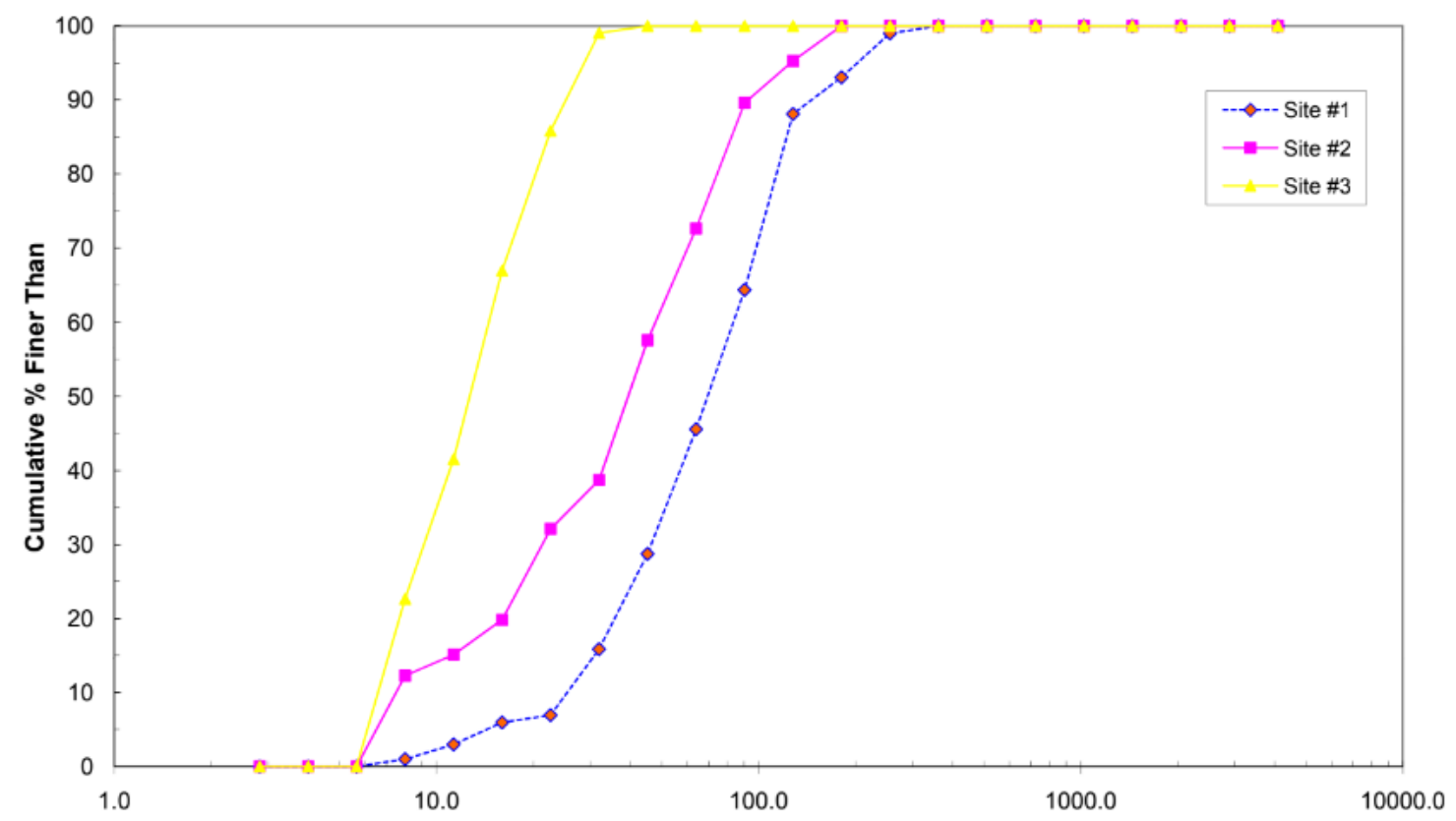

Figure 6.5 Particle size distributions from the three study sites within the Tryon Creek stream bed (Source: City of Portland).

It was further concluded that the bar features are more frequent upstream of Hwy 43, further illuminating that sediment sources are present throughout the watershed and impacted by 
the presence of the culvert. In the project reach between the Hwy 43 culvert and the confluence with the Willamette River, bar features were comprised mostly of the gravel deposited in the creek during Phase I of the confluence habitat improvement and will likely wash away downstream. Throughout the project reach, it was noted that during most of the year Tryon Creek easily transports sediments downstream with the larger angular basaltic rocks being deposited on the bar features. At times when the Willamette River is at high volume, it can reduce the flow rates of Tryon Creek and cause fine sediment deposition in the channel which will be washed away as rates return to normal. At the confluence of Tryon Creek, it is suggested that the channel be spread out among multiple channels to contribute to a fanned floodplain layout, reducing flow rates and allowing for larger sediments to remain intact (Herrera Environmental Consultants, 2009). These larger sediments are useful for aquatic organism habitat throughout the stream. Erosion of fine sediments can be reduced by adding more channel complexity through large woody debris (LWD). This would consequently also reduce fine sediment impacts on the watershed as well as channel incision. Other benefits of LWD include sediment deposition zones, habitat for fish, and slowing flow velocities.

\section{Conclusions}

Characteristics of Tryon Creek that make it susceptible to sediment production and transport are the steep slopes, channel confinement, and concentrated development within the watershed (City of Portland, 2009). Much of the development took place without the health of the watershed in mind, leading to stormwater drainage that carries fine sediments and pollutants directly to the stream system. Impervious surfaces contribute to peak storm flows that deliver coarse and fine sediment to the creek. These sediments have negative impacts on the aquatic habitat and its organisms including smothering rock surfaces and eggs, as well as decreased visibility (City of Portland, 2009).

The hydrology of Tryon Creek is influenced by many factors, including impervious surfaces, the loss of headwater streams, and the construction of piped storm systems. Along with alteration of the hydrology, sediment deposition has also been affected. This natural process is typically amplified in urban environments lacking proper storm drainage systems that direct water (City of Portland, 2012). Without these systems, water can run directly from buildings, streets, and landscaping, over the hard to infiltrate soil and directly into the stream system. This eliminates the function that soil plays as storage and filtration for water, causing fine sediments and pollutants to accumulate in the stream affecting the aquatic habitat. It was found by the City of Portland that in the Tryon Creek watershed, curbed streets best decrease fine sediment sources when compared to uncurbed and unimproved streets. Unimproved street surfaces are subject to erosion and contribute nearly half of the TSS in stormwater runoff to the Tryon Creek watershed although they represent less than $10 \%$ of the streets. An example of street improvement with the watershed health in mind is the Tryon-Stephens Headwaters Neighborhood Street Plan, which has a goal for PBOT and BES to improve an area of the city planned without consideration for the topography or watershed (City of Portland, 2015). The agencies worked with community members to redesign street and stormwater drainage infrastructure in a way best for the residents as well as the natural environment. All development and redevelopment projects within the City of Portland must follow the Stormwater Management Manual (SWMM) design guidelines that control stormwater runoff and industrial pollution. A tactic of the SWMM for water diversion is the use of vegetated facilities that filter stormwater as it moves through the soil toward stormwater drainage. This effort and others throughout the watershed are a step toward better stormwater management and reduction of higher than natural influences of fine sediment sources into Tryon Creek. 


\section{Data Gaps}

Although assessment of the roads exists, it would be beneficial to have an updated understanding of roads and other impervious surfaces currently within the watershed. Areas with significantly reduced infiltration and water holding capacity caused by compaction and conversion of native vegetation should also be assessed and converted to an equivalent impervious area via reasonable coefficients in order to fully assess effects of land use on runoff. Debris flow hazard maps would also be useful to understand where sediment inputs into the creek. This information can help guide future project and infrastructure planning throughout the watershed.

\section{References}

Barton, A. (2019). Image of basaltic bedrock in Marshall Park. Tryon Creek Watershed Council.

City of Lake Oswego (2013). Comprehensive Plan. Volume I.

City of Lake Oswego (2015). Hydromodification Assessment.

City of Portland, Bureau of Environmental Services (2005). Fanno and Tryon Creeks Watershed Management Plan.

City of Portland, Bureau of Environmental Services (2012). Fanno and Tryon Watersheds Street Drainage Overview.

City of Portland, Bureau of Transportation (2015). Tryon-Stephens Headwaters Neighborhood Street Plan.

Haritashya, U., et al. (2010). Particle size characteristics of suspended sediment transported in meltwater from the Gangotri Glacier, central Himalaya - An indicator of subglacial sediment evacuation. Geomorphology Volume 122, Issues 1-2.

Herrera Environmental Consultants (2009). Tryon Creek Confluence Habitat Enhancement Design Report. City of Portland Bureau of Environmental Services.

Rhodes, J. (2002). Overview of Existing Condition, Data Gaps and Recommendations for the Protection and Restoration of Aquatic Resources. West Multnomah Soil and Water Conservation District.

Williams, P. \& Coulton, K. (1997). Phase 1 Data Review of Hydrologic and Geomorphic Conditions in the Upper Tryon Creek Watershed, 1997. Prepared for West Multnomah Soil and Water Conservation District.

Wolman, M. (1954). A Method of Sampling Coarse River-bed Material. Transactions, American Geophysical Union. Volume 35, Number 6. 


\section{CHANNEL MODIFICATIONS ASSESSMENT}

\section{Introduction}

The path and structure of streams can change due to both natural and anthropogenic influences within the watershed. Storms, erosion, and ecological changes are examples of natural factors while culverts, piping, and impervious surface runoff are human-caused channel modifications. Through scientific studies, researchers can observe the effects of historic and current channel modifications and renovate when appropriate. A current focus of the Tryon Creek Watershed Council and partner agencies is to identify priority channel modifications that require replacement or restructuring based on impacts to fish passage and other watershed processes. Urban streams in Portland, including Tryon Creek, have been diverted, piped, and even disregarded during development of the residential and urban infrastructure. This has had large effects on the biotic function of the creek and negatively impacted habitat for fish and other aquatic organisms. Historic images depict the confluence of Tryon Creek meandering and with more channel complexity than it is today. Such a scenario would help to prevent flooding and provide habitat for aquatic organisms. Many instances of instream modification and development throughout the watershed are not recorded through permits or otherwise (Callison, 2003). That would include development of stream crossings, ponds, and other structures on private properties which are difficult to inventory.

When learning about stream impacts, it is important to also consider the effects of development in the watershed surrounding the creek, including increased impervious surfaces. The impacts of impervious surfaces, including reduced rainfall infiltration and increased stormwater runoff volume and velocity, then modify the channel structure of the creek (City of Portland, 2008). Efforts that focus on stormwater management and restoration of natural drainage are beneficial.

Storm drain outfalls are constructed throughout the watershed that allow untreated runoff to flow into the creek from streets, parking lots, and commercial development. Wastewater sewer pipes run parallel to and cross large portions of the creek and tributaries. When functioning properly, there is no effect on the creek, yet they can become blocked or backed up resulting in spillage of sewage into the stream (Callison, 2003). Additionally, the sewer mains are occasionally flushed with toxic chemicals to break up organic matter buildup or tree roots that have grown through joints in the cement sewer pipes. The chlorinated effluent (secondary level treatment) that drains into the Willamette River from the Tryon Creek Wastewater Plant near the confluence of Tryon Creek and the river has negative effects on fish habitat. There is speculation that the temperature or chemical makeup of this waste can repel salmon and other aquatic organisms from Tryon Creek.

\section{Methodology}

\section{Data Inventory and Sources}

To learn more about the influence of channel modifications in and around Tryon Creek, the first step was to compile a list of those modifications. Potential channel modifications include roads, realignment, railway, pipeline, dikes, riprap, channelization, gravel pits, and reservoirs. To find information about the location and types of development that may have an effect on the aquatic habitat of the stream, research online and in the library as well as interviews were conducted. Table 7.1 presents a list of common activities that result in channel modifications and the potential impacts from such activities (Watershed Professionals Network, 1999). These features 
are all considered potential channel modifications and are not all found within the Tryon Creek watershed.

Table 7.1 Common stream channel modifications and potential impacts (Source: Watershed Professionals Network).

\begin{tabular}{|l|l|}
\hline \multicolumn{1}{|c|}{ Channel Modification Activity } & \multicolumn{1}{c|}{ Potential Impacts } \\
\hline Hydroelectric and irrigation dams & $\begin{array}{l}\text { Migration barrier, loss of spawning and rearing habitat, } \\
\text { non-native fish introduction }\end{array}$ \\
\hline Reservoirs and artificial impoundments & Flow alteration, loss of spawning gravels \\
\hline $\begin{array}{l}\text { Small agricultural impoundments, cattle } \\
\text { ponds, fire ponds }\end{array}$ & $\begin{array}{l}\text { Migration barrier, loss of spawning and rearing habitat, } \\
\text { non-native fish introduction, water quality impacts }\end{array}$ \\
\hline Dikes, levees (usually for flood control) & $\begin{array}{l}\text { Loss of side-channels and floodplain function, decrease in } \\
\text { channel length, and reduction of habitat complexity }\end{array}$ \\
\hline $\begin{array}{l}\text { Channelization (channel straightening, } \\
\text { hardening, or relocation) }\end{array}$ & $\begin{array}{l}\text { Reduction in key habitat features such as pools and sorted } \\
\text { gravel }\end{array}$ \\
\hline Dredged channels & Decrease in habitat complexity \\
\hline $\begin{array}{l}\text { Stream-bank protection (riprap, pilings, } \\
\text { bulkheads) }\end{array}$ & $\begin{array}{l}\text { Decrease in lateral scour pools; likely to incite bank } \\
\text { erosion downstream }\end{array}$ \\
\hline $\begin{array}{l}\text { Built-up areas in floodplains, in/near } \\
\text { estuaries, wetlands, and channels }\end{array}$ & $\begin{array}{l}\text { Loss of side-channels, flood attenuation, and food-chain } \\
\text { support }\end{array}$ \\
\hline Tide gates & Loss of off-channel rearing areas and food-chain support \\
\hline Roads next to streams & Loss of side-channels, lateral pools, and riparian function \\
\hline Extensive fill associated with road crossings & Loss of habitat complexity, downstream erosion \\
\hline Gravel dams & Migration barrier, habitat loss, flow alteration \\
\hline $\begin{array}{l}\text { Sand and gravel mining in/near channels, } \\
\text { tailings deposits }\end{array}$ & Pool filling, decreased habitat complexity \\
\hline
\end{tabular}

Members of the Tryon Creek Watershed Council (TCWC), local agency employees, and other community members were interviewed to gather information about existing channel modifications. Location and purpose of the modifications were the focus of the interviews. The locations and dates of historic channel modifications are approximate. Participation in TCWC board meetings and other community events has provided further information. Other documents reviewed include historic society notes and historical texts and displays. Relatively few accounts were found that described in-channel modifications; most of the historical records pertained to changes in land use and demographics.

Another source of data for channel modifications was USGS 7.5-minute topographic maps. These maps were used to identify dikes, levees, dredged channels, excessive road fill, stream crossings, and channel straightening and relocation. USGS maps, GIS data, and aerial photographs were reviewed to identify channel modifications that have potential effects on the stream ecosystem.

\section{Evaluation of Impact}

After collecting information, each listed item was assessed in regard to the impact level and rated as low, moderate, and high impact. Determining the degree of impact is based on channel habitat types, fish distribution, and current knowledge of interactions between physical, chemical, and biological changes in and around a stream. There is some subjectivity in the final decision, yet it is most helpful to draw conclusions from relative impact levels when prioritizing future projects and renovations. Channel habitat types were covered in section 3 of this watershed assessment while fish and fish habitat will be covered in section 9, both containing more detail on these topics. Briefly, the distribution of channel habitat types and fish species were used to determine stream 
reach sensitivity to present channel modifications. Table 7.2 contains the general guidelines used to evaluate negative impacts. It should also be noted that level of impact is evaluated for the current ecosystem of Tryon Creek and not time of development. Finally, the last step was to inventory and map the location and type of each of the channel modifications.

Table 7.2 Conditions for the potential degree of impact of channel modifications (Source: Watershed Professionals Network).

\begin{tabular}{|l|l|}
\hline $\begin{array}{c}\text { Potential } \\
\text { Degree of } \\
\text { Impact }\end{array}$ & Indicators \\
\hline Low & $\begin{array}{l}\text { - Impacts likely only affect a small area }(\sim<\% \text { of channel); } \\
\text { - Channel characteristics such as pattern, width, substrate type, bank erosion, pool } \\
\text { features, and large woody debris distribution are largely unaffected; } \\
\text { - Fish are absent or assumed absent from the affected portion of the stream channel. }\end{array}$ \\
\hline Moderate & $\begin{array}{l}\text { - Impacts are localized, but apparent; } \\
\text { - Changes to channel characteristics such as pattern, width, substrate type, bank } \\
\text { erosion, pool features, and LWD distribution are detectable, but not obvious; } \\
\text { - Fish are present or fish distribution is unknown within the affected portion of the } \\
\text { stream channel. }\end{array}$ \\
\hline High & $\begin{array}{l}\text { - Impacts are obvious with large changes of in-channel characteristics such as pattern, } \\
\text { - A significant length of the channel is affected; } \\
\text { - Fish are present or fish distribution is unknown within the affected portion of the } \\
\text { stream channel. }\end{array}$ \\
\hline
\end{tabular}

\section{Results}

Culverts of road crossings are the most prevalent and recorded channel modifications of the watershed. Also impactful is piping of the stream although records are not complete. Almost all of the impacts are moderate or high impact based on fish passage solely. A summary of the channel modification points and each of their degree of impact is displayed in Table 7.3. Reports detailing culvert and other channel modifications presence are sparse, therefore this is not a complete list and should be expanded as more channel modifications throughout the watershed are identified. Particularly, ponds and other structures on private land are not well-documented. Figure 7.1 is an image of the piped culvert that diverts Tryon Creek under Atwater Rd on Nettle Creek. This structure with a large drop in elevation between the pipe and the stream bed prevents aquatic plant growth and is likely not passable for anadromous or resident fish. 
Table 7.3 Summary of channel modifications and their estimated degree of impact to fish passage (Sources: City of Portland, Tryon Creek Watershed Council, and City of Lake Oswego).

\begin{tabular}{|c|c|c|c|}
\hline Sub-watershed & Description/Location & Modification Type & Impact \\
\hline Tryon Creek & $\begin{array}{l}\text { Above-ground wastewater } \\
\text { main pipeline }\end{array}$ & Dredged channels & Moderate \\
\hline Tryon Creek & $\begin{array}{l}\text { Below-ground wastewater } \\
\text { pipes }\end{array}$ & Dredged channels & Moderate \\
\hline Tryon Creek & Hwy 43 & Road crossing & High \\
\hline Tryon Creek & SW Boones Ferry Rd & Road crossing & High \\
\hline Tryon Creek & SW Maplecrest Ct & Road crossing & High \\
\hline Tryon Creek & Marshall Cascades & Natural rock barrier & High \\
\hline Tryon Creek & $\mathrm{SW} 18^{\text {th }} \mathrm{Pl}$ & Road crossing & High \\
\hline Tryon Creek & SW Lancaster St & Road crossing & High \\
\hline Tryon Creek & SW Taylors Ferry Rd & Road crossing & Low \\
\hline Tryon Creek & SW $26^{\text {th }}$ Ave & Road crossings (3) & Moderate \\
\hline Tryon Creek & SW Barbur Blvd (I-5) & Road crossing & High \\
\hline Tryon Creek & SW Spring Garden St & Road crossings (3) & Moderate - High \\
\hline Tryon Creek & SW Hume St & Road crossing & Moderate \\
\hline Tryon Creek & SW Carson St & Road crossing & High \\
\hline Tryon Creek & SW $31^{\text {st }}$ and SW Carson & Road crossing & Low \\
\hline Tryon Creek & SW $31^{\text {st }}$ Ave & Road crossing & High \\
\hline Tryon Creek & Confluence to Hwy 43 & Fill material & Moderate \\
\hline Arnold Creek & SW Arnold Rd & Road crossings (2) & Moderate - High \\
\hline Arnold Creek & Arnold Cascades & Natural rock barrier & Moderate \\
\hline Arnold Creek & $\mathrm{SW} 16^{\text {th }} \mathrm{Pl}$ & Road crossing & High \\
\hline Arnold Creek & SW Arnold St & Road crossing & Moderate \\
\hline Arnold Creek & SW Lancaster Rd & Road crossing & High \\
\hline Arnold Creek & SW $35^{\text {th }}$ Ave & Road crossing & Moderate \\
\hline Falling Creek & SW $26^{\text {th }}$ Ave & Road crossing & Moderate \\
\hline Falling Creek & SW $35^{\text {th }}$ Ave & Road crossing & High \\
\hline Falling Creek & SW Huber St & Road crossing & High \\
\hline Falling Creek & $\begin{array}{l}\text { SW } 39^{\text {th }} \text { Ave (Jackson Middle } \\
\text { School) }\end{array}$ & Road crossing & High \\
\hline Falling Creek & SW Pomona St & Road crossing & Moderate \\
\hline Nettle Creek & SW Atwater Rd & Road crossing & High \\
\hline Quail Creek & SW Lancaster Rd & Road crossing & High \\
\hline Quail Creek & SW Quail Post Rd & Road crossing & Moderate \\
\hline Other tributaries & SW Taylors Ferry Rd & Road crossing & High \\
\hline Other tributaries & Marigold St & Road crossing & High \\
\hline Other tributaries & $\mathrm{SW} 18^{\text {th }} \mathrm{Pl}$ & Road crossing & High \\
\hline Other tributaries & SW Broadleaf Dr. & Road crossing & High \\
\hline Other tributaries & SW Dolph Ct & Road crossing & High \\
\hline Other tributaries & $\begin{array}{l}\text { SW } 30^{\text {th }} \text { Ave and Spring } \\
\text { Garden Rd }\end{array}$ & Road crossing & High \\
\hline
\end{tabular}




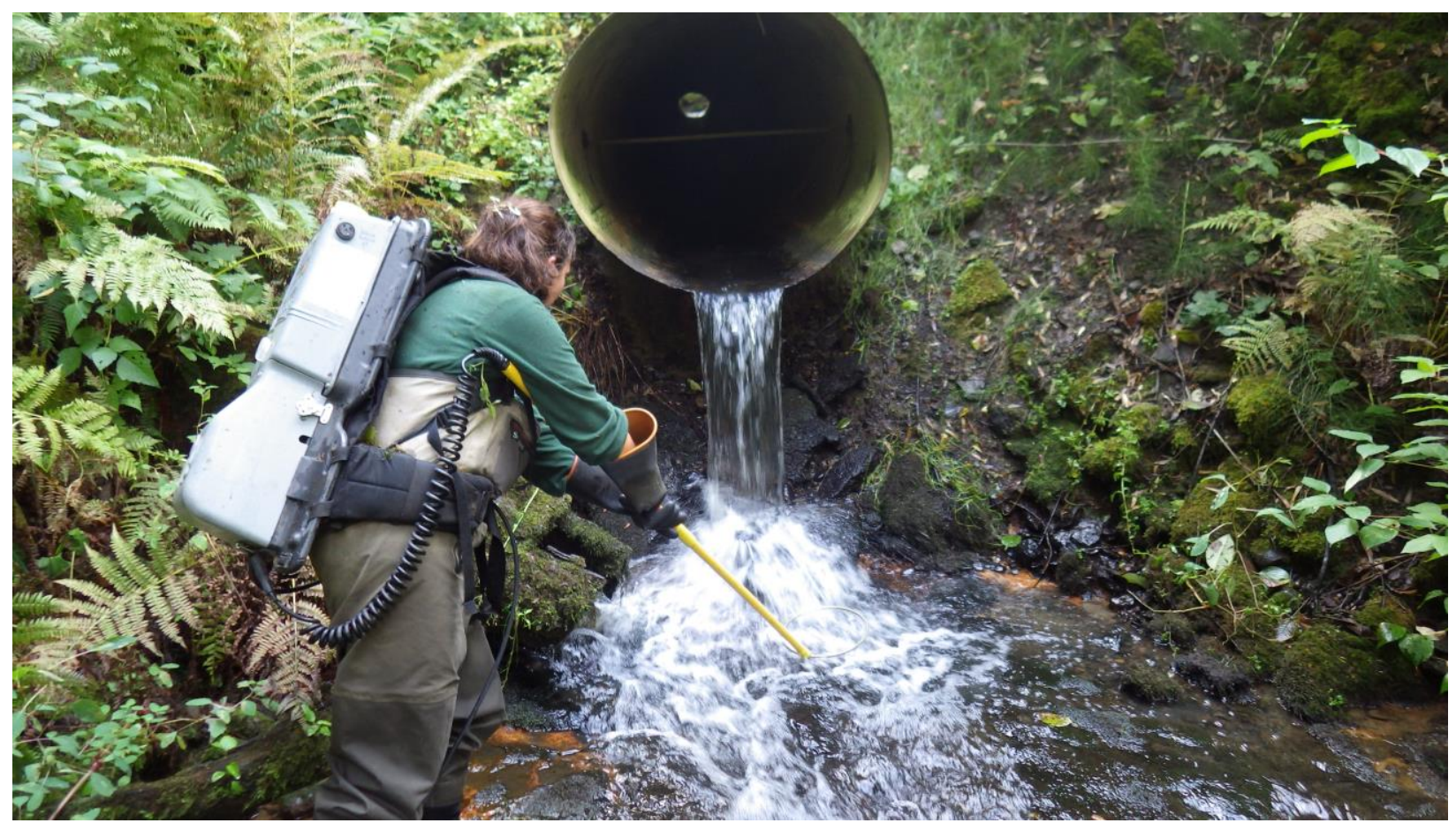

Figure 7.1 United States Fish and Wildlife Service (USFWS) scientist surveys for fish below the Atwater Rd culvert to interpret the impacts of culverts on the native fish population (Source: United States Fish and Wildlife Service).

One of the current project topics is the replacement and improvement of culverts throughout the watershed. The Boones Ferry Rd crossings is being redesigned in an effort to be more hospitable to fish passage. The Hwy 43 culvert was originally constructed in the 1920 s and spans approximately $400 \mathrm{ft}$ with an average grade of $4.6 \%$ (Silver, et al, 2017). The culvert was retrofitted in 2008 with a new baffle system to improve habitat, yet it is still not passable for salmonid species (USFWS, 2012). The Hwy 43 culvert replacement by the United States Army Corps of Engineers has been authorized. Relative to the rest of the watershed, there are very few barriers within the Tryon Creek State Natural Area (City of Portland, 2005).

Another impactful project was the 1960s development of the sewer system that parallels a large portion of Tryon Creek. Disturbance of the stream bank and riparian environment opened area to invasive plant species. On the other hand, this project improved water quality throughout the watershed by redirecting sewer water to the Tryon Creek Wastewater Treatment Plant. Previous to installation of sewers, most private wastewater was disposed of in septic system, impacting Tryon Creek water quality when issues occurred.

In 2005 , it was estimated that $9 \%$ of the stream banks were artificially hardened while the remaining were composed of natural materials including clay, gravel, and sand (City of Portland, 2005). Although, it is important to remember that practices such as landscaping, road crossings, and residential development have consequently hardened banks.

Further increases in peak flows and sediment loads can be prevented through the protection of the stream bank conditions and riparian vegetation (City of Portland, 2005). Continued channel incision and loss of in-channel complexity could further decrease the creek's ability to retain large woody debris. This loss would mean decreased habitat functionality of Tryon Creek (City of Portland, 2005). In an effort to maintain the condition of the stream, the City of Portland and other agencies have worked to improve stormwater drainage systems throughout the watershed. Table 
7.4 lists completed projects. Efforts that involve naturalization of riparian zones or stormwater paths can benefit the channel health of a stream. Green streets that include swales for water filtration and storage are being developed in many locations within the Tryon Creek watershed. Restoration of piped streams to open channels would benefit the drainage ability of the stream as well as its aquatic habitat character (City of Portland, 2008).

Table 7.4 List of completed restoration projects throughout the Tryon Creek watershed (Source: City of Portland).

\begin{tabular}{|l|l|}
\hline \multicolumn{1}{|c|}{ Sub-watershed } & \multicolumn{1}{c|}{ Project Description } \\
\hline Tryon Creek & I-5 and SW 26 ${ }^{\text {th }}$ Ave terraced rain gardens \\
\hline Tryon Creek & Multnomah Arts Center stormwater swales \\
\hline Tryon Creek & Multnomah Blvd stormwater retrofits \\
\hline Tryon Creek & Multnomah Village green streets \\
\hline Tryon Creek & Spring Garden Park daylighting \\
\hline Tryon Creek & D Ave reconstruction and swales \\
\hline Tryon Creek & SW Stephenson roadside swales \\
\hline Tryon Creek & $\begin{array}{l}\text { TriMet park and ride on SW Barbur Blvd and Capitol Hwy } \\
\text { stormwater retrofit }\end{array}$ \\
\hline Tryon Creek & Hwy 43 culvert retrofit and stream enhancement \\
\hline Tryon Creek & Confluence stream bank stabilization \\
\hline Tryon Creek & Headwaters restoration and rain garden \\
\hline Tryon Creek & Iron Mountain stream restoration \\
\hline Tryon Creek & Middle Tryon Creek restoration \\
\hline Falling Creek & Baldock service yard stormwater retrofits \\
\hline Falling Creek & SW Portland outfall repair \\
\hline Quail Creek & SW Huber St green street project \\
\hline Other tributaries & SW 19 ${ }^{\text {th }}$ residential street and stormwater project \\
\hline Other tributaries & SW Marigold green street \\
\hline
\end{tabular}

\section{Conclusion}

Urban watersheds are often impacted negatively by development in and around the stream bed. Impervious surfaces within a watershed cause stormwater drainage to infiltrate streams at a high velocity. While channel modifications within the stream can have direct impacts on the habitat quality for fish and other aquatic organisms. More information regarding fish distribution can be found in section 9 of this watershed assessment. Culverts under road crossings are the most often documented type of channel modification with impacts on the stream ecology (City of Portland, 2005).

Historic construction decisions continue to impact the health of the watershed in unintentional ways, for example it may have made sense to run a wastewater pipe parallel to the stream where a channel already existed. Yet, studies find that the wastewater pipe provides instances of erosion and even pollution (Callison, 2003). As knowledge of the needs of stream ecosystems expands, the cities of Portland and Lake Oswego have improved previous channel modifications. Through construction of swales, rain gardens, and stream daylighting, aquatic habitat can be improved within a watershed (City of Portland, 2014). 


\section{Data Gaps}

This section was completed through the review of resources that are both outdated and focused on small sections of the watershed. Like other sections of the watershed assessment, this was completed through combing through resources and developing understanding of watershed processes. Channel modifications on private land are not included because there is not a reliable source of information with a complete list of such impacts.

\section{References}

Callison, E. (2003). Watershed Issues: Land Use and Zoning, Riparian Protection, Municipal Regulatory Permits, Water Quality. West Multnomah Soil and Water Conservation District.

City of Portland, Bureau of Environmental Services (2005). Fanno and Tryon Creeks Watershed Management Plan.

City of Portland, Bureau of Environmental Services (2008). Fanno/Tryon Water Quality and TMDL CIP Pre-design \#7622 Report.

City of Portland Bureau of Environmental Services (2014). Tryon Creek Confluence Habitat Enhancement Project Update.

City of Portland (2019). Completed Projects. https://www.portlandoregon.gov/bes/64118. Accessed 11-6-2019.

Rhodes, J. (2002). Overview of Existing Condition, Data Gaps and Recommendations for the Protection and Restoration of Aquatic Resources. West Multnomah Soil and Water Conservation District.

Silver, B., et al (2017). Tryon Creek Restoration Monitoring Project. US Fish and Wildlife Service Columbia River Fish and Wildlife Conservation Office.

United States Fish and Wildlife Service, Columbia River Fisheries Program Office (2012). Tryon Creek Restoration Monitoring and Assessment.

Watershed Professionals Network (1999). Oregon Watershed Assessment Manual. Governor's Watershed Enhancement Board. Salem, Oregon. 


\section{WATER QUALITY ASSESSMENT}

\section{Introduction}

Water quality encompasses the physical, chemical, and biological characteristics that can be measured to make conclusions about the health of a body of water. The purpose of this section of the watershed assessment is to note water quality parameters of concern for restoration and the protection of listed beneficial uses. When addressing water quality issues throughout Oregon, the Department of Environmental Quality (DEQ) and other agencies have adopted a watershed approach in which water quality issues throughout the watershed are approached through management of the entire watershed. Rather than response focused on individual and often overlapping issues, the health of the whole watershed is considered in regard to sources of environmental problems (City of Portland, 2008). Through this approach, solutions are intended to address multiple issues for more efficient and money saving efforts. Additionally, a watershedlevel approach acknowledges that many processes within a watershed are large scale and interactive. A pollutant source at the headwaters, for example, will affect the health of the creek downstream as well as at the point of influence.

Water quality is a broad term and is influenced by factors that have already been discussed in the previous sections of this watershed assessment. Specifically, water temperature is dependent on riparian and wetland conditions discussed in section 4 while total suspended solids and pollutants are impacted by sediment sources (section 6). Components that will be addressed in this section include temperature, dissolved oxygen, $\mathrm{pH}$, nutrients, bacteria, chemical contaminants, and turbidity.

Water quality regulation was inspired by the composition of the Clean Water Act (CWA) and the Endangered Species Act (ESA). The ESA was written in 1973 to protect threatened and endangered plant and animal species and the ecosystems in which they live. Habitat modification is defined as a type of harm that is unlawful under this act if it "kills or injures fish by significantly impairing essential behavioral patterns such as feeding, sheltering, rearing, migrating, breeding, and spawning" (City of Portland, 2008). Critical habitat for Chinook is established in lower Tryon Creek while critical habitat for Coho and steelhead is established throughout all mainstem reaches of Tryon Creek up to Marshall Cascades. This designation of critical habitat necessitates that projects that will directly or indirectly impact listed Coho (threatened), steelhead (threatened), or Chinook (threatened) or their habitats must pass federal consultation with NOAA. Projects aimed at the improvement of habitat likely consider the conservation needs of ESA-listed species (City of Portland, 2008). The CWA was written in 1972 and has later been amended with the goal of maintaining clean water throughout the United States for drinking, recreation, and wildlife purposes (Oregon Department of Environmental Quality, 2017). This statute requires that states take care of their water bodies to state-written and federally approved standards. This includes the identification of impaired waters that are "water quality limited," in that they do not meet water quality standards for one or more parameters (City of Portland, 2008). The result of this effort is that each state has a $303(\mathrm{~d})$ list which includes the water bodies that need to be addressed for exceedance of water quality standards.

The Oregon DEQ reviews and revises its water quality standards every three years in order to submit to the EPA for approval (Oregon Department of Environmental Quality, 2017). Oregon water quality standards are set for each body of water based on its most sensitive beneficial uses, whether that is for human or wildlife. According to the CWA, a standard is composed of beneficial uses, an anti-degradation policy, and criteria to meet (Oregon Department of Environmental Quality, 2006). Once a water body has been listed on the Oregon 303(d) list, a total maximum daily 
load (TMDL) is calculated by DEQ and serves as a tool representing the maximum amount of a pollutant allowed to enter a waterbody to ensure that the waterbody is able to meet water quality standards. A pollutant reduction target is then set based on the TMDL value (Environmental Protection Agency, 2019). Local jurisdictions, or the designated management agencies (DMAs) are responsible for working with landowners to achieve the TMDL for each body of water. The DMAs of Tryon Creek would include the cities of Portland and Lake Oswego, Oregon Parks and Recreation Department, Oregon Department of Transportation and other entities with legal authority over a sector or source of water quality pollutants (Oregon Department of Environmental Quality, 2006). All point and nonpoint sources should be identified and allocated a portion (with a margin of safety) to calculate a TMDL and individual allowable loads. Tryon Creek is included on the Lower Willamette Sub-basin TMDL report for temperature (City of Portland, 2008).

Section 402 of the CWA, the National Pollutant Discharge Elimination System (NPDES) Stormwater Program was specifically developed for the control of point and nonpoint sources of pollution to waters throughout the nation (City of Portland, 2005). The City of Portland was issued an Municipal Separate Storm Sewer System (MS4) permit through Oregon DEQ and is therefore required to reduce pollutants carried in stormwater runoff and wastewater discharges from the Tryon Creek Wastewater Treatment Plant through a series of categories of stormwater quality best management practices (BMPs) (City of Portland, 2008). The permit also requires that the city establish pollutant load reduction benchmarks for the existing TMDL parameters. A comprehensive stormwater management program has been developed to address these issues not only at the water bodies of interest, but also throughout the whole city (City of Portland, 2005).

Impacts of water quality issues are numerous, yet one of the most concerning is that on salmon and other aquatic organisms. Increased water temperature can reduce egg viability, increase damage of diseases, and favor warm temperature tolerant species (Rhodes, 2002). Water temperature can increase from loss of shade-providing riparian vegetation, reduced low flows, and stormwater runoff from warmer surfaces which are all associated with urbanization. Development directly affects the physical habitat throughout the watershed and influence of stormwater runoff (City of Portland, 2008). Summer in-stream temperatures of Tryon Creek have been found to exceed the water quality standard set for protection of salmon rearing (City of Portland, 2008). Also exceeding water quality standards are measurements of E. coli levels in about $20 \%$ of the samples in reported in a 2008 report. Sources of bacteria include human sources such as storm drainage and failed septic systems and non-human sources such as livestock, pets, raccoons, and other animals (City of Portland, 2005). The creek was ranked as poor on the Oregon Water Quality Index due to high levels of bacteria, total suspended solids, and nutrients (total phosphorus, ammonia, and nitrogen). Pollutants as well as silts and other sediments are transported into Tryon Creek at high proportions through stormwater runoff originating in urban parts of the watershed (City of Portland, 2008). Pollutants sources include automobiles (metals, petroleum, etc.), landscaping, development, and industrial operation leaks (City of Portland, 2012). As discussed in section 6, fine sediments accumulate in deep pools, altering aquatic habitats that are already degraded by channelization and lack of in-stream complexity. Excess nutrients such as phosphorus and nitrogen are also associated with low levels of dissolved oxygen (City of Portland, 2005). Largely impactful channel modifications that lead to poor water quality are the areas around the Hwy 43 and Boones Ferry Road culverts. These zones slow water, causing warmer water, sediments, and pollutants to collect upstream (City of Portland, 2005). 


\section{Methodology}

The fundamental steps for a water quality assessment are to first identify sensitive beneficial uses, then select the evaluation criteria, identify data sources and assemble existing water quality data, evaluate the data for selected parameters, and finally draw conclusions. The beneficial uses of Tryon Creek have been described in the Introduction section. Once beneficial uses of the watershed are identified, reasonable water quality evaluation criteria are selected based on the needs of the most sensitive beneficial uses. These criteria serve as limits that each water quality parameter must meet to allow the sensitive beneficial use to be supported in the creek. For example, for a stream $303(\mathrm{~d})$ listed for temperature, the most sensitive beneficial use is typically fish and other aquatic organisms. Salmonid rearing and spawning require relatively cold water for survival of the young fish. The criteria of temperature identify a 7 -day average maximum of temperatures, with focus on the times of the year during which fish species are spawning and rearing. If the stream does not meet the criteria, it is put on the 303 (d) list and a TMDL is prepared by the state. Once the criteria are defined, then a TMDL is set and load allocations are distributed to sources of heat that affect the temperature of the creek.

\section{Sensitive Beneficial Uses}

Sensitive beneficial uses applicable to this water quality assessment are listed in table 8.1. Salmonid fish are the most sensitive beneficial uses in this watershed for most of the parameters, therefore guiding the evaluation criteria. The salmonid species currently found during monitoring of Tryon Creek include Coastal Cutthroat Trout, resident Rainbow Trout and anadromous Steelhead Trout, Coho Salmon, and Chinook salmon (Silver, et al., 2018). These species are adapted to cold waters with high levels of dissolved oxygen. A life cycle attribute that these diverse fish have in common is that they lay eggs in the gravel of a stream or riverbed and the fry rear close to where they hatch from the egg. The sensitivity of these life stages to changes of temperature, dissolved oxygen, and suspended solids is high (Watershed Professionals Network, 1999).

Table 8.1 Identified beneficial uses of Tryon Creek (Source: Watershed Professionals Network).

\begin{tabular}{|l|}
\hline \multicolumn{1}{|c|}{ Beneficial Use } \\
\hline Aesthetic quality \\
\hline Domestic water supply \\
\hline Fish and aquatic life \\
\hline Irrigation \\
\hline Salmonid fish rearing \\
\hline Salmonid fish spawning \\
\hline Water contact recreation \\
\hline
\end{tabular}

\section{Evaluation Criteria}

There is an evaluation criterion set for each water quality parameter. The evaluation criteria are written as a value that the parameter must not exceed either within a single reading or average in order to have no effect on the identified sensitive beneficial uses. If a sample is found to exceed an evaluation criterion, then that sample is noted as impaired for that water quality parameter. Most often evaluation criteria are set as single reading exceedances, while temperature is measured as the average of the maximum temperatures recorded during a seven-day period. The temperature criteria are based on the cold water needed for salmon rearing and spawning throughout the year. 
Temperature data must meet the criteria for rearing year-round and for spawning through fry emergence October 15 - May 15. Table 8.2 shows the evaluation criteria applicable to Tryon Creek based on the sensitive beneficial uses and impaired samples. According to Oregon's 2012 Integrated Report Assessment Database and 303(d) list, Tryon Creek is impaired for biological criteria, dissolved oxygen, and temperature. There are other attributes of concern as discussed in the introduction, yet those described in table 8.2 have been sampled at levels that are considered impaired. Biological criteria and dissolved oxygen were added to the $303(\mathrm{~d})$ list in recent years and do not yet have a TMDL set. For temperature, the Oregon state standard is that surface water temperature shall increase no more than $0.3^{\circ} \mathrm{C}$ when surface water temperature criteria are exceeded (Oregon Department of Environmental Quality, 2006). The primary identified source of heat loading is solar radiation, which is a nonpoint source, meaning that there are no set load allocations for point sources of heat in Tryon Creek. Rather, shade targets are set throughout the watershed as a surrogate measure of load allocations of heat.

Table 8.2 Evaluation criteria applicable to Tryon Creek (Source: Oregon Department of Environmental Quality).

\begin{tabular}{|l|l|l|l|}
\hline $\begin{array}{l}\text { Water Quality } \\
\text { Parameter }\end{array}$ & $\begin{array}{c}303(\mathrm{~d}) \\
\text { listed }\end{array}$ & \multicolumn{1}{|c|}{ Evaluation Criteria } & \multicolumn{1}{c|}{ Status } \\
\hline $\begin{array}{l}\text { Biological } \\
\text { Criteria }\end{array}$ & 2010 & $\begin{array}{l}\text { Macroinvertebrate taxa loss may not equal } \\
\text { or exceed 15\% }\end{array}$ & $\begin{array}{l}\text { Cat 5: Water quality limited } \\
\text { (15\% or more taxa loss), 303(d) } \\
\text { list, TMDL needed. }\end{array}$ \\
\hline $\begin{array}{l}\text { Dissolved } \\
\text { Oxygen }\end{array}$ & 2012 & $\begin{array}{l}\text { Not less than 11.0 mg/L or 95\% of } \\
\text { saturation for the period October 15 - May } \\
15\end{array}$ & $\begin{array}{l}\text { Cat 5: Water quality limited, } \\
\text { 303(d) list, TMDL needed }\end{array}$ \\
\hline Temperature & 1998 & $\begin{array}{l}\text { May not exceed a 7-day average maximum } \\
\text { of } 13^{\circ} \mathrm{C} \text { for the period October 15 - May 15 } \\
\text { and } 18^{\circ} \mathrm{C} \text { the rest of the year. }\end{array}$ & Cat 4A: TMDL approved \\
\hline
\end{tabular}

\section{Data Sources}

Water quality information has been collected from Oregon DEQ, United States Fish and Wildlife Service (USFWS), and the City of Portland. The biological criteria and dissolved oxygen data were provided in the 2012 Integrated Report Assessment Database and 303(d) list, which was approved by the EPA in 2018 (Oregon Department of Environmental Quality, 2012). These data supported listing Tryon Creek for those two parameters and therefore exceeded statewide standards. DEQ performs multivariate predictive models to represent the macroinvertebrate population in conditions with minimal disturbance. Reference samples are then compared to the model and rated in regard to percentage of potential taxa present. Macroinvertebrate species can tolerate a range of disturbances, meaning that their presence can indicate aquatic conditions. Dissolved oxygen data collection for the 2012 Integrated Report focused on the Willamette River Basin, which includes Tryon Creek.

The USFWS collects temperature with temperature loggers located at Nettle Creek, $26^{\text {th }}$ and Taylor's Ferry Rd, and Tryon Creek upstream of Nettle Creek during annual surveys. Temperature readings can also inform about other conditions of a stream including influence of runoff or hospitality to more resilient fish and aquatic organisms.

The City of Portland maintains a Portland Area Watershed Monitoring and Assessment Program (PAWMAP) that delivers regular report cards of each of the metropolitan watersheds. For composition of the report card, the city measures temperature, E. coli, dissolved oxygen, total suspended solids, ammonia-nitrogen, dissolved copper, total mercury, and total phosphorus. A goal 
of the PAWMAP is to measure indicators focused on hydrology, physical habitat, water quality, and fish and wildlife in order to produce an understanding of the watersheds in question for the community to interpret. With an understanding of watershed characteristics, the city can focus efforts on specific and city-wide efforts for the overall health of the region (City of Portland, 2018). The result is a report card that grades each of those four watershed categories, yet this report will focus on the water quality. Data of collection methods are not available.

\section{Results}

\section{Biological Criteria}

Tryon Creek was added to the 303 (d) list for biological criteria (bio-criteria) in the 2010 DEQ assessment and a TMDL is still needed. A biological criteria assessment is an evaluation of the condition of a waterbody based on a biological survey of species that spend all or part of their lives in the waterbody (Environmental Protection Agency, 2011). A study site is compared to reference sites and surveyed for species categorized based on level of sensitivity to stress and ability to tolerate pollution. Biological criteria in the Marine Western Coastal Forest (MWCF) is measured as $15 \%$ or more loss of benthic macroinvertebrate taxa potentially including insects, snails, crayfish, and worms (Oregon Department of Environmental Quality, n.d.). The MWCF is described as land ranging from British Columbia to California on the west of the Cascades mountain range. Supporting data for the listing of Tryon Creek for biological criteria is in table 8.3.

Table 8.3 Supporting data for justification of listing Tryon Creek for bio-criteria (Source: Oregon Department of Environmental Quality).

\begin{tabular}{|l|c|l|}
\hline River Mile & Date & Dissolved Oxygen Measures \\
\hline o.7 & $8 / 23 / 2006$ & 1 out of 1 samples $\geq 15 \%$ or more loss of taxa \\
\hline 1.1 & $8 / 19 / 2002$ & 1 out of 1 samples $\geq 15 \%$ or more loss of taxa \\
\hline 1.1 & $8 / 12 / 2004$ & 1 out of 1 samples $\geq 15 \%$ or more loss of taxa \\
\hline 1.4 & $8 / 22 / 2007$ & 1 out of 1 samples $\geq 15 \%$ or more loss of taxa \\
\hline 1.9 & $8 / 22 / 2007$ & 1 out of 1 samples $\geq 15 \%$ or more loss of taxa \\
\hline 2.2 & $8 / 22 / 2007$ & 1 out of 1 samples $\geq 15 \%$ or more loss of taxa \\
\hline 2.7 & $8 / 30 / 2006$ & 1 out of 1 samples $\geq 15 \%$ or more loss of taxa \\
\hline 3.2 & $8 / 15 / 2007$ & 1 out of 1 samples $\geq 15 \%$ or more loss of taxa \\
\hline 3.4 & $8 / 24 / 2006$ & 1 out of 1 samples $\geq 15 \%$ or more loss of taxa \\
\hline 3.4 & $8 / 30 / 2006$ & 1 out of 1 samples $\geq 15 \%$ or more loss of taxa \\
\hline 3.5 & $9 / 13 / 2006$ & 1 out of 1 samples $\geq 15 \%$ or more loss of taxa \\
\hline 4.3 & $7 / 24 / 2007$ & 1 out of 1 samples $\geq 15 \%$ or more loss of taxa \\
\hline 5 & $8 / 23 / 2006$ & 1 out of 1 samples $\geq 15 \%$ or more loss of taxa \\
\hline
\end{tabular}

\section{Dissolved Oxygen}

Tryon Creek was added to the 303(d) list for dissolved oxygen in the 2012 DEQ assessment and a TMDL is still needed. Supporting data for listing the creek for dissolved oxygen is in table 8.4. For this parameter, there is a minimum value set that can still support the beneficial uses, rather than a maximum. Continuation of cold-water spawning is dependent on sufficient levels of dissolved oxygen (Oregon Department of Environmental Quality, 2019). 
Table 8.4 Supporting data for justification of listing Tryon Creek for dissolved oxygen (Source: Oregon Department of Environmental Quality).

\begin{tabular}{|l|c|l|}
\hline River Mile & \multicolumn{1}{|c|}{ Dates } & \multicolumn{1}{c|}{ Dissolved Oxygen Measures } \\
\hline 0.3 & $3 / 20 / 2006-11 / 17 / 2011$ & $\begin{array}{l}5 \text { of 11 samples }<11.0 \mathrm{mg} / \mathrm{l} \text { and }<95 \% \\
\text { saturation }\end{array}$ \\
\hline 1.1 & $5 / 7 / 2004-5 / 7 / 2004$ & $\begin{array}{l}\text { 1 of 1 samples }<11.0 \mathrm{mg} / \mathrm{l} \text { and }<95 \% \\
\text { saturation }\end{array}$ \\
\hline
\end{tabular}

\section{Temperature}

During summer field studies in 2013, the USFWS collected temperature using a logger at Nettle Creek. Figure 8.2 displays the hourly temperature readings recorded at Nettle Creek from June 3 to September 2, 2013. This is not during the spawning months, so the 7 -day average maximum is $18^{\circ} \mathrm{C}$ (marked with a red horizontal line), which is met or exceeded on 22 of the 96 days.

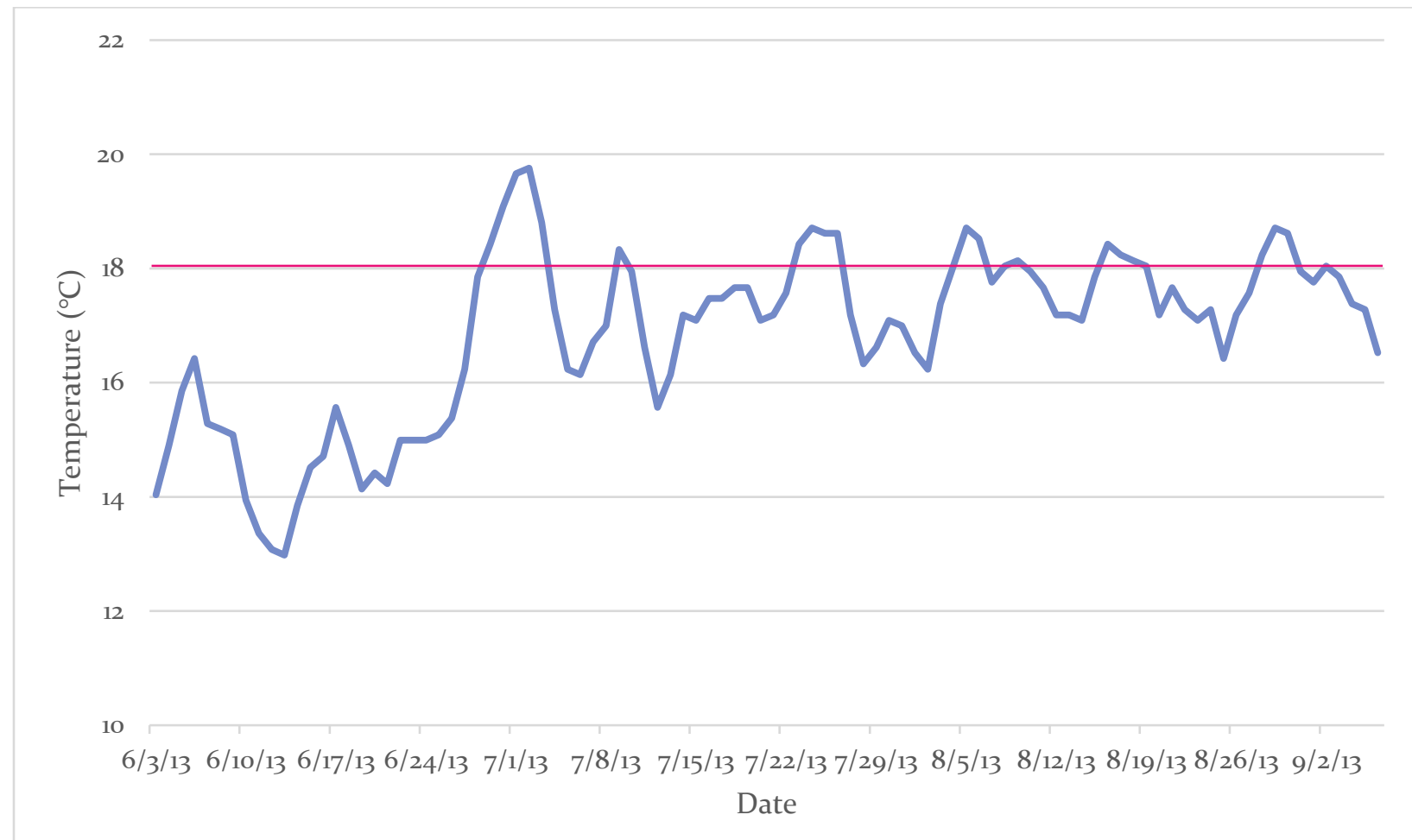

Figure 8.2 Hourly temperature readings during the summer of 2013 (Source: United States Fish and Wildlife Service).

\section{Other parameters}

The PAWMAPS rating is an easy to interpret option for the City of Portland to share watershed health status with the community. Measurement results from these studies are not available at this time. Table 8.5 and figure 8.3 show the 2019 scores and their relativity to the same study conducted in 2015. Overall, the Tryon Creek watershed was rated a B-for water quality which is a score that leaves room for improvement. It is noted that suspended solids and the pollutants that can bind to them in stormwater drainage are a concern for this watershed (City of Portland, 2019). Runoff that enters the stream untreated can also carry dissolved copper that enters the environment from automobile brake pads and is consequently harmful to salmon health. Finally, 
stream temperatures exceed healthy limits during the summer when ambient air temperature is higher and stream flows are lower.

Table 8.5 Scores of the water quality parameters measured in 2019 and how they compare to the 2015 readings (Source: City of Portland).

\begin{tabular}{|l|l|l|}
\hline \multicolumn{1}{|c|}{ Parameter } & \multicolumn{1}{|c|}{ 2019 score } & \multicolumn{1}{c|}{ Relative to 2015 score } \\
\hline Ammonia-nitrogen & 9.9 & No change \\
\hline Dissolved copper & 5.9 & Increased slightly \\
\hline Dissolved oxygen & 8.6 & Increased slightly \\
\hline E. coli & 2.9 & Decreased \\
\hline Temperature & 4.9 & Decreased slightly \\
\hline Total mercury & 1.8 & No change \\
\hline Total phosphorus & 6.3 & Decreased slightly \\
\hline Total suspended solids & 3.8 & Decreased \\
\hline
\end{tabular}

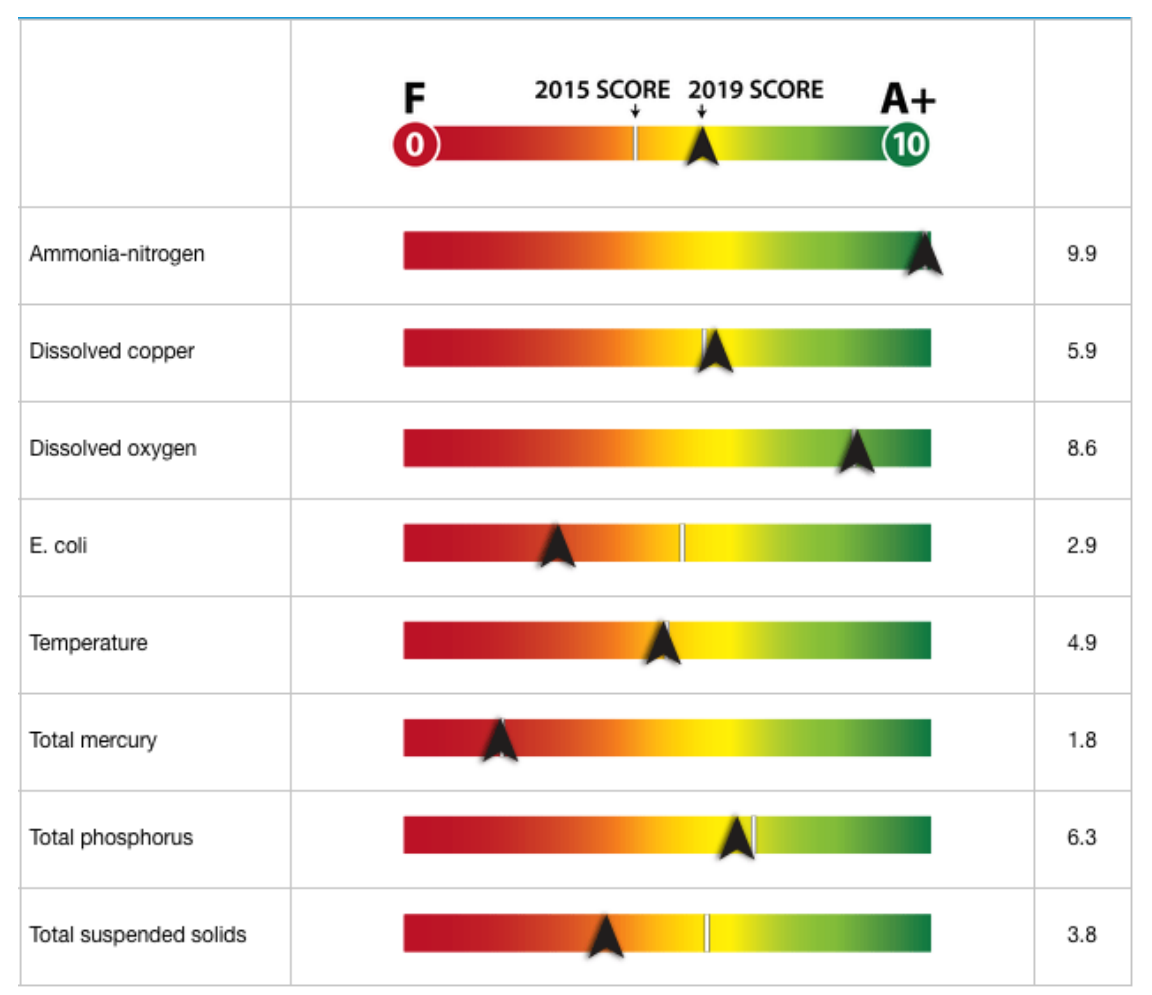

Figure 8.3 each of the water quality parameters and the corresponding scores that combined to create the water quality report card rating (Source: City of Portland).

\section{Conclusion}

More data is needed to make conclusions regarding biological criteria and dissolved oxygen. Both parameters are set to have a TMDL created by the DEQ, per the 2012 state-wide assessment. Aquatic macroinvertebrates serve as an indicator of biological conditions for the health of a stream for many reasons. For research purposes, they are relatively easy to collect and identify. They also differ in tolerance to environmental conditions, meaning that the species present can inform about the impacts of pollutants and other stressors (Klatte \& Ellis, 2001). Additionally, macroinvertebrates 
make up lower reaches of the food web as an important food source for birds, fish, and other organisms. Loss of taxa represents a degradation of ecological health of a watershed, therefore making biological criteria an important water quality parameter to improve.

Dissolved oxygen is also key for survival of aquatic organisms because it allows those who breathe through water to survive. Dissolved oxygen is more abundant in water that is moving rather than stagnant. Colder waters can actually hold more oxygen than warm, linking dissolved oxygen and temperature as cooperating attributes. Alternatively, bacteria has an inverse relationship with dissolved oxygen because it can consume oxygen as organic matter decays (United States Geological Service, n.d.). Aquatic zones with low levels of dissolved oxygen can fail to support life and are called "dead zones".

Tryon Creek hosts salmon and other fish species throughout their life cycles, yet the most sensitive, as far as temperature, are salmon spawning and rearing. The spawning criterion is $13^{\circ} \mathrm{C}$ and that for rearing is $18^{\circ} \mathrm{C}$. A TMDL has been made for temperature in the Tryon Creek watershed. Climate and geology are natural influences on stream temperature that are outside of human control (Oregon Department of Environmental Quality, 2006). Most other sources of heat are often related to human activities such as alteration of riparian vegetation and development within the watershed. Loss of riparian vegetation often causes a decrease in stream shading and increase in sun exposure. While development typically introduces altered channel morphology and reduction in summertime base flows due to introduction of impervious surfaces. The direct impacts of urbanization on stream temperature are difficult to measure, yet its consequences listed above can be studied in relation to temperature. Another influence on water temperature is diversion of water through water rights or other means. As discussed in section 6, there are a dozen active water withdrawal rights throughout the watershed. Water diversion can alter the stream water temperature by lowering the flow which slows the water and exposes a larger proportion to sun, both increasing the temperature (Oregon Department of Environmental Quality).

Interpretation of the 2019 PAWMAPS data can be concluded that although Tryon Creek is relatively healthier than other watersheds in the Portland metro area, there are points of improvement. The lowest scores received were for total mercury (1.8/10), E. coli (2.9/10), and total suspended solids (3.8/10). These parameters should be the focus of restoration to avoid being included on the $303(\mathrm{~d})$ list in the future.

\section{Data Gaps}

There are very few water quality data collection sites from which conclusions were drawn to represent the whole watershed. It would be useful to have more collection sites in order to draw conclusions based on the health of each sub-watershed. Additionally, the biological criteria and dissolved oxygen are newly listed parameters, meaning that there is no TMDL and few data available to discuss.

\section{References}

City of Portland, Bureau of Environmental Services (2005). Framework for Integrated Management of Watershed Health

City of Portland, Bureau of Environmental Services (2005). Fanno and Tryon Creeks Watershed Management Plan.

City of Portland, Bureau of Environmental Services (2008). Fanno/Tryon Water Quality and TMDL CIP Pre-design \#7622 Report

City of Portland, Bureau of Environmental Services (2018). Portland Area Watershed Monitoring and Assessment Program Executive Summary- Findings from Years 1-4. 
City of Portland, Bureau of Environmental Services (2018). Portland Area Watershed Monitoring and Assessment Program. Tryon Creek Report Card.

Environmental Protection Agency (2011). Biological Assessments: Key Terms and Concepts. EPA/820/F-11/oo6

Environmental Protection Agency (2019). Overview of Total Maximum Daily Loads (TMDLs). Accessed at epa.gov.

Klatte, B. \& Ellis, R. (2001). Macroinvertebrate Sampling Report. West Multnomah Soil and Water Conservation District.

Oregon Department of Environmental Quality (n.d.). Chronology of Bio-criteria Assessment in Oregon.

Oregon Department of Environmental Quality (2006). Willamette Basin TMDL.

Oregon Department of Environmental Quality (2012). 2012 Integrated Report Assessment Database and $303(\mathrm{~d})$ List.

Oregon Department of Environmental Quality (2017). NPS [Nonpoint Source] Program Annual Report.

Oregon Department of Environmental Quality (2019). Methodology for Oregon's 2018 Water Quality Report and List of Water Quality Limited Waters.

Oregon Water Resources Department (2018). Water Rights Information Query Results.

Rhodes, J. (2002). Overview of Existing Condition, Data Gaps and Recommendations for the Protection and Restoration of Aquatic Resources. West Multnomah Soil and Water Conservation District.

Silver, B., et al. (2018). Tryon Creek Restoration Monitoring Project, City of Portland FY 2018 Progress Report. U.S. Fish and Wildlife Service, Columbia River Fish and Wildlife Conservation Office.

United States Geological Service (n.d.). Dissolved Oxygen and Water. Accessed at https://www.usgs.gov/special-topic/water-science-school/science/dissolved-oxygen-andwater?qt-science center objects=o\#qt-science center objects

Watershed Professionals Network (1999). Oregon Watershed Assessment Manual. Governor's Watershed Enhancement Board. Salem, Oregon. 


\section{FISH AND FISH HABITAT ASSESSMENT}

\section{Introduction}

This is an evaluation of available information related to fish populations present in the Tryon Creek watershed. Many of the other sections are related to fish and fish habitat. Although all fish species are part of the ecological web, this assessment will focus on species of scientific and ecological concern. Fish populations are a measure of the health of a watershed, making it a vital topic to include within a watershed assessment. Fish passage migration barriers were briefly discussed in section 7 of this watershed assessment. The most impactful barriers that affect Tryon Creek is culverts that are not passable by salmonid and other fish species. Figure 9.1 displays identified fish passage barriers, and the identifying agency, throughout the watershed. The majority of barriers are in the headwaters of Tryon Creek, yet the Hwy 43 culvert, about $1 / 4$ mile from the confluence with the Willamette River currently serves as the most detrimental to fish migration. 


\section{Tryon Creek Watershed Council}

Fish Passage Barriers

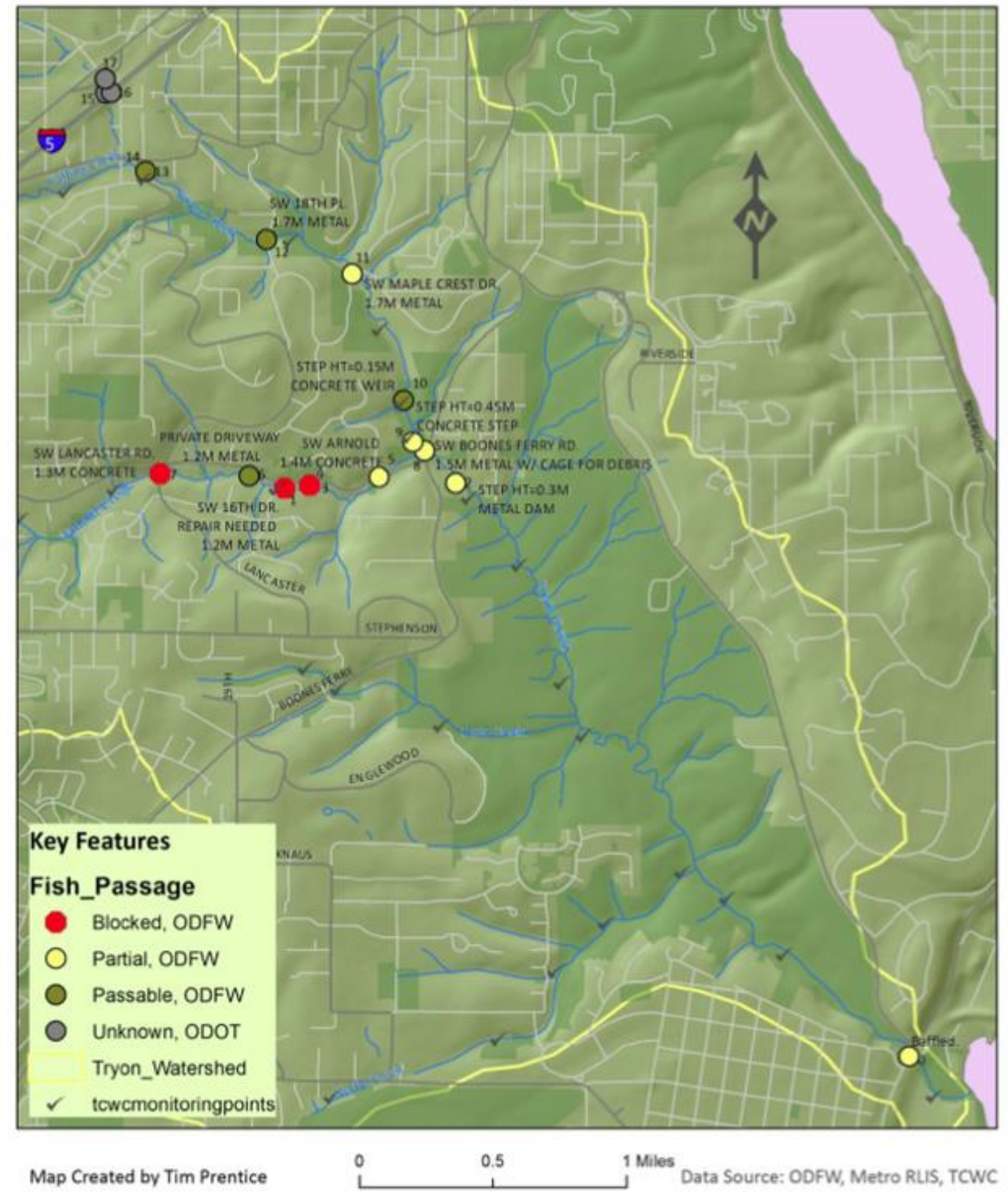

Figure 9.1 Map of fish passage barriers throughout the Tryon Creek Watershed (Source: Prentice, T.). 


\section{Methodology}

This assessment will be focused on the species of concern and their biological conditions. The current status and recent trends in abundance will also be discussed. The health of salmonid and other fish species is key to prioritizing restoration projects throughout the watershed. Regular monitoring provides an opportunity to draw connections between fish population and land management. This will be especially informative after the replacement of impactful culverts that serve as fish passage barriers. This assessment relies on data from the United States Fish and Wildlife Service (USFWS) annual monitoring project report of fish populations of Tryon Creek. The focus of this program is to assess the impacts of fish passage barriers, specifically the Hwy 43 culvert, through estimations of fish presence and abundance used to describe the fish community (Silver, et al., 2019). A Passive Integrated Transponder (PIT) array at the mouth of Tryon Creek records tagged fish as they enter and exit the stream. Fish collections, salmon species abundance estimates, and electrofishing surveys for larval lampreys were also conducted. The primary monitoring reach extended from the mouth of Tryon Creek to downstream of the Hwy 43 culvert. Sixteen reaches between the Hwy 32 culvert and the Boones Ferry Road culvert and three reaches in Upper Tryon Creek up to the SW Maplecrest Drive culvert were also established (Figure 9.2). 


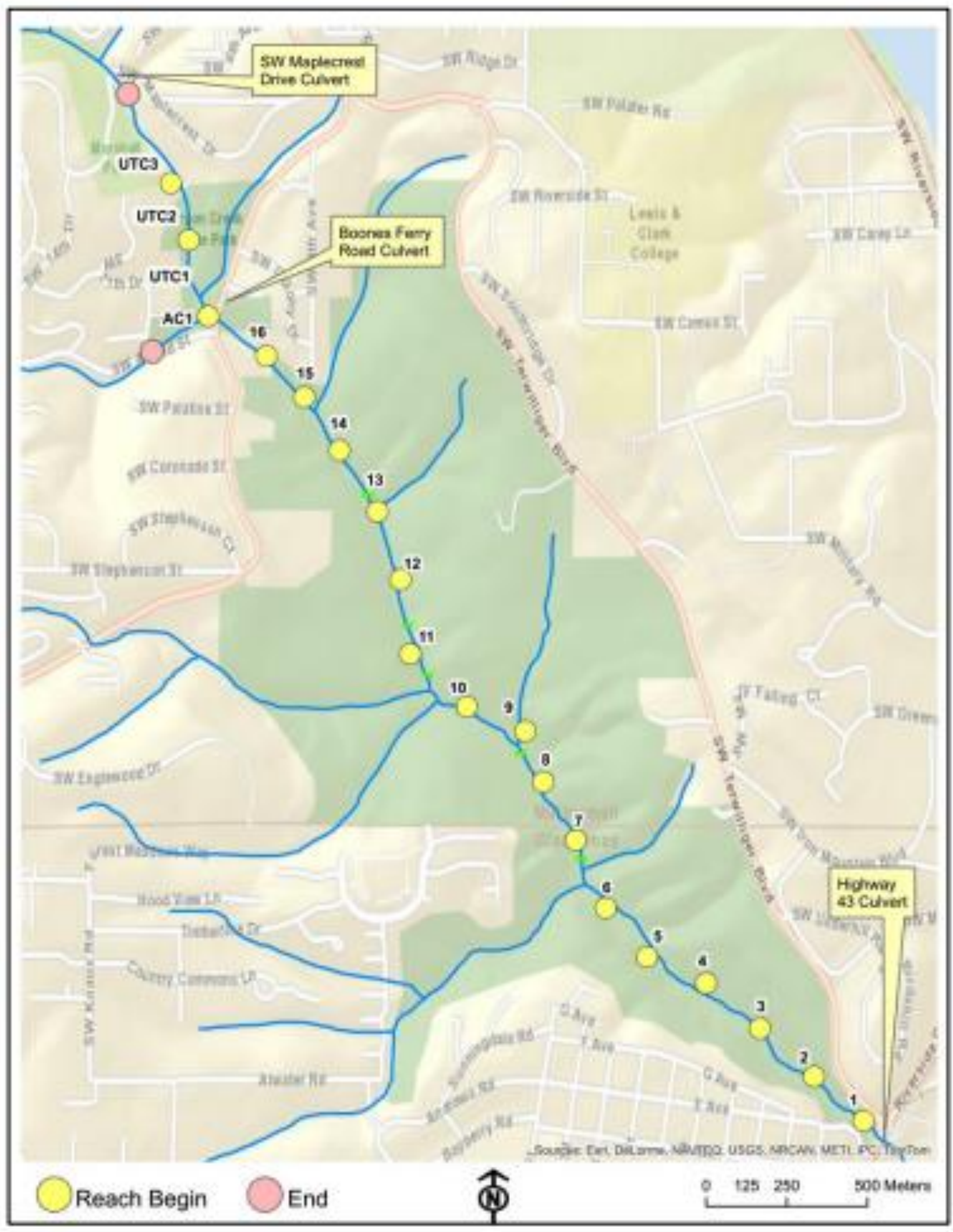

Figure 9.2 Tryon Creek abundance estimate study area (Source: United States Fish and Wildlife Service). 


\section{Results}

\section{Status and Distribution of Species of Concern}

Table 9.1 lists the species of concern and their federal and state level statuses in regard to the Endangered Species Act (ESA) and Oregon Department of Fish and Wildlife (ODFW). The value of having a federal (ESA) and state (ODFW) status for each species is that the most restrictive listing takes precedence. The ESA provides listing of distinct plants and animals as threatened or endangered for conservation purposes. A status on the endangered species list affects research and stewardship targeted for a species. In addition, the USFWS and the National Oceanic and Atmospheric Administration (NOAA) are in charge of policies, guidance, and enforcement of protection for those species listed (Environmental Protection Agency, n.d.).

Table 9.1 Status of Species of Concern within the Tryon Creek watershed (Source: Oregon Department of Fish and Wildlife).

\begin{tabular}{|l|l|l|}
\hline \multicolumn{1}{|c|}{ Species } & \multicolumn{1}{c|}{ ESA status } & ODFW status \\
\hline Coho & Threatened (2004) & Endangered \\
\hline Spring Chinook & Threatened (1999) & Not Listed \\
\hline Winter Steelhead & Threatened (1999) & Critical \\
\hline Pacific Lamprey & Not Listed & Vulnerable \\
\hline
\end{tabular}

\section{Coho (Oncorhynchus kisutch)}

Coho return to the Willamette basin as two-year-old jacks and three-year adults from late August through early November. Spawning generally peaks from September through December. Coho tend to spawn in small, low-gradient areas with fast-flowing waters and small to large gravel substrates (City of Portland, 2005). Fry emerge from mid-January to April and seek out shallower waters during early stages of life. The majority of fingerlings emigrate from March through midJuly of their second year. Coho generally return to their natal streams at three and four years of age. It is believed that Coho historically spawned in lower and middle Tryon Creek and that their current presence below the Hwy 43 culvert indicates they would return to these sections of the creek if the culvert were passable (Portland Parks and Recreation, 2009).

\section{Winter Steelhead (Oncorhynchus mykiss)}

The Clackamas and Tualatin River populations of winter steelhead are believed to be laterun species that return to the Willamette River from the ocean to spawn during their fifth and sixth year. Their return to freshwater is typically from October to May, with spawning beginning in March. This species takes advantage of the high flows and cold temperatures found in Tryon Creek throughout the winter (City of Portland, 2005). Habitat and water temperature are factors that affect egg hatch and fry emergence, which can be in the winter or early spring. Fry grow from riffletype habitats to pools, often becoming inactive in winter months and even burrowing in the stream bottom. Juvenile steelhead spend two years in freshwater before smolting, triggered by light stimulus, water temperature, and water chemistry. Emigration peaks in early April and extends through early June (City of Portland, 2005). Similar to Coho, it is believed that steelhead migrated 
as far upstream as middle Tryon Creek reaches (Portland Parks and Recreation, 2009). Rainbow trout are $\mathrm{O}$. mykiss that are considered resident fish that do not migrate to the ocean during their lifetime.

\section{Coastal Cutthroat Trout (Oncorhynchus clarkia)}

Return to home streams occurs between July and March. It is common for cutthroat to migrate upstream of Coho and steelhead to avoid competition. Fish that survive spawning overwinter in fresh water and emigrate in the spring, typically prior to smolt emigration (City of Portland, 2005). Upon emergence, fry seek shallow waters with low-velocity flow until they are juveniles and can withstand varied stream conditions. Smolting takes places around age three or four and schools are formed prior to and maintained during saltwater migration. The coastal cutthroat is not currently listed as a species of concern in the Willamette Basin, yet it is one of the species discussed in this assessment because it is listed in other watersheds and it is historically an important species present in Tryon Creek and the rest of the Willamette Basin. The USFWS reviewed a proposal to add coastal cutthroat as a threatened species and determined that it was not warranted in 2010 (United States Fish and Wildlife, 2010). Coastal cutthroat have been observed entering and exiting the creek, demonstrating potential for both resident and migratory populations not impacted by urbanization (Portland Parks and Recreation, 2009). Hybridization between coastal cutthroat and O. mykiss is known to occur (Silver, et al., 2017).

\section{Spring Chinook (Oncorhynchus tshawytscha)}

Recent data confirms that juvenile and adult chinook continue to rear and reside in the lower confluence region (Portland Parks and Recreation, 2009). Young fish typically emigrate toward the ocean March through May at age two (Schroeder, et al., 2015). The fish return to freshwater between March and June (Oregon Department of Fish and Wildlife, 2005). Chinook spawn in relatively deeper water than other salmon and typically in late summer or early fall. Adults generally die within two weeks after spawning.

\section{Observations from the Tryon Creek Restoration Monitoring Project}

Based on total captures between 2012 and 2018, sculpin are the most abundant family in Tryon Creek, followed by Coho salmon with a quarter of the sample size. Figure 9.3 demonstrates sample sizes of all the fish captured during surveys 2012-2018 with an asterisk $\left({ }^{*}\right)$ marking introduced species. $34 \%$ of the PIT tagged fish were recaptured at least once with the recapture rates of Coastal Cutthroat and hybrid trout being the highest at 0.54 and 0.73 , respectively. 


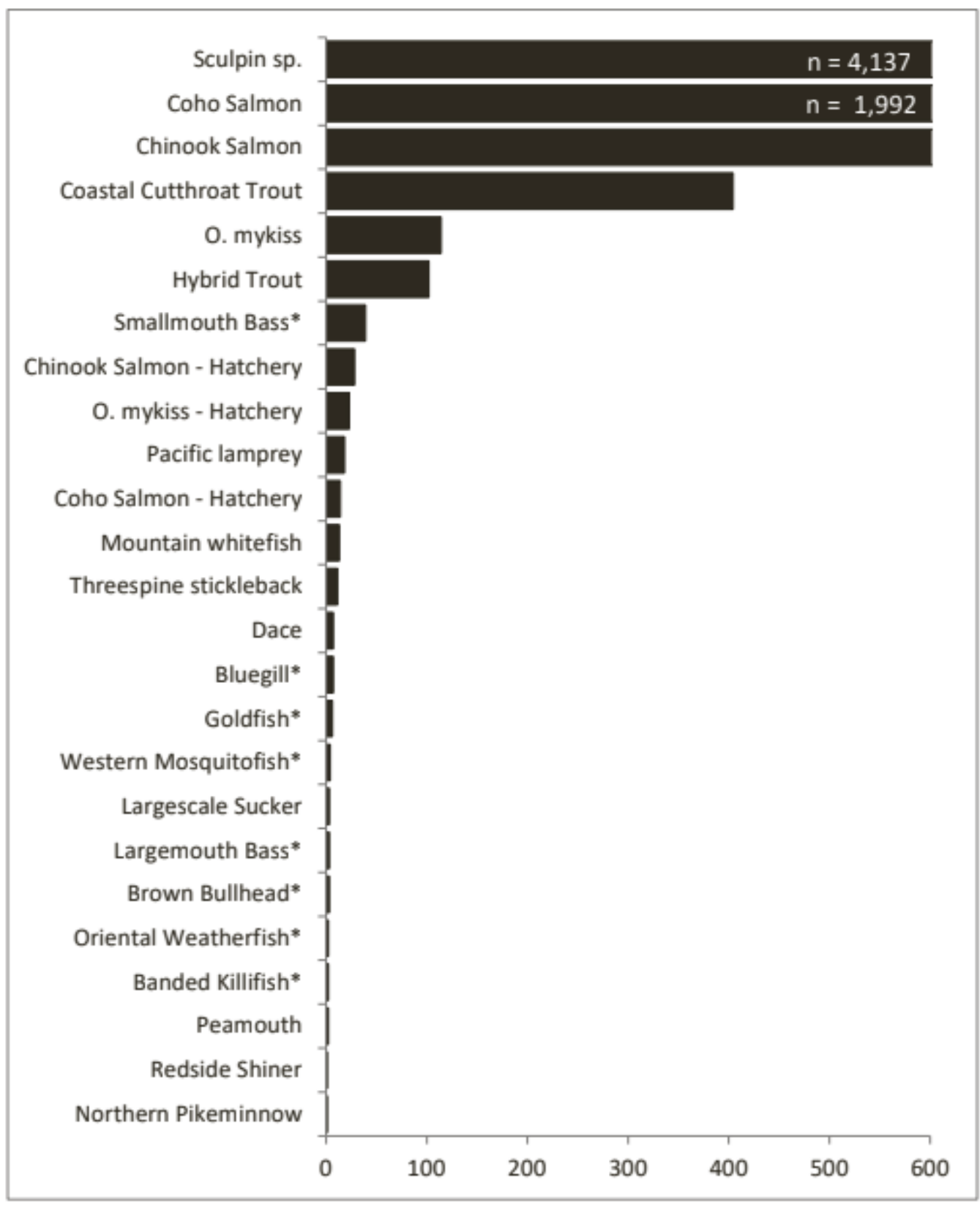

Figure 9.3 Total fish captured in the Tryon Creek Confluence habitat 2012 - 2018 (Source: United States Fish and Wildlife Service).

Ecological classification indicates Coho salmon, Chinook salmon, coastal cutthroat trout, and sculpin as dominant species compared to O. mykiss and hybrid trout based on capture frequency. Of the 764 unique PIT tag detections, $81 \%$ were previously implanted in juvenile migratory salmonids. $96.2 \%$ of the PIT tags detected were from fish tagged in Tryon Creek below the Hwy 43 culvert. Unique detections per month peaked in June for Coho salmon and December for Chinook salmon. Notably, a Coho that had been tagged as a juvenile in 2017 in the lower portion of Tryon Creek was captured entering the Clackamas River in 2018. This demonstrates that fish are successfully spawning and surviving within the Tryon Creek watershed to the point that they are found in other locations of the Willamette River Basin. 
Pacific Lamprey and Western Brook Lamprey are believed to have historically been present in Tryon Creek, yet are not able to pass detrimental fish passage barriers (Silver, et al., 2019). Between 2005 and 2012, 29 larval Pacific Lamprey, one western brook lamprey, and 6 larval lamprey of unidentified species were caught in the reach below the Hwy 43 culvert while none were caught above the culvert.

\section{Conclusion}

As a sensitive group, salmonids are a useful indicator of environmental conditions. The biological requirements of salmon are well understood and are a key determinant of water quality and other watershed maintenance parameters. It is generally understood that a watershed that can support native salmon can also support other important hydrological functions (City of Portland, 2005). Steelhead and other native fish populations have recently been recorded at declining populations throughout the Willamette basin (Klatte \& Ellis, 2002). USFWS research confirms that fish are present in Tryon Creek, mainly below the Hwy 43 culvert. The culvert is also found to be completely impassable for native lamprey species (Silver, et al., 2019). Consequently, the pool below the culvert has been identified as a productive site for multiple fish species. Habitat restoration that prioritizes formation of pools and complex stream structure would benefit salmon and other fish populations. Retention of large woody debris provides natural complexity to a stream bed (National Riparian Service Team, 2001). Additionally, removal of fish passage barriers would allow access to stream channels previously inaccessible for salmon (City of Portland, 2005). Increasing spawning area possibilities will drastically affect potential population productivity.

\section{Data Gaps}

There are few data gaps related to fish populations of Tryon Creek. Annual reports of an ongoing USFWS project have provided consistent data related to fish presence.

\section{References}

City of Portland, Bureau of Environmental Services (2005). Fanno and Tryon Creeks Watershed Management Plan.

Environmental Protection Agency (n.d.). Summary of the Endangered Species Act. Accessed at https://www.epa.gov/laws-regulations/summary-endangered-species-act.

Klatte, B. \& Ellis, R. (2002). Tryon Creek Environmental Baseline Conditions and Limiting Factors Analysis for Anadromous Salmonids. West Multnomah Soil and Water Conservation District.

National Riparian Service Team (2001). Tryon Creek PFC Assessment. West Multnomah Soil and Water Conservation District.

Oregon Department of Fish and Wildlife (2005). Oregon Native Fish Status Report.

Portland Parks and Recreation (2009). Habitat Management and Trail Plan Marshall Park Natural Areas.

Prentice, T. (2013). Tryon Creek Watershed Council Fish Passage Barriers. Christina Friedle Portland Community College course.

Schroeder, R., et al. (2015). Juvenile life-history diversity and population stability of spring Chinook salmon in the Willamette River basin, Oregon. Canadian Journal of Fisheries \& Aquatic Sciences. 2016, Vol. 73 Issue 6, p921-934. 14p. 
Silver, B., et al. (2017). An Urban Stream Can Support A Healthy Population of Coastal Cutthroat Trout.

Silver, B., et al. (2019). Tryon Creek Restoration Monitoring Project. City of Portland FY 2018 Progress Report. United States Fish and Wildlife Service. Columbia River Fish and Wildlife Conservation Office.

United States Fish and Wildlife Service (2010). Withdrawal of Proposed Rule To List the Southwestern Washington/Columbia River Distinct Population Segment of the Coastal Cutthroat Trout as Threatened. Federal Register. 


\section{WATERSHED EVALUATION}

\section{Introduction}

The previous sections of this watershed assessment address natural processes and human influences that alter the landscape and aquatic habitats on a watershed scale. It is acknowledged that land use and resource management practices- historic as well as current- can alter natural processes within a watershed. The Tryon Creek Watershed Council prioritizes their role as a connection between stakeholders throughout the watershed as well as stewardship project leader. The council continues to plan, complete, and maintain projects of all scales that improve the riparian and stream environment. Figure 10.1 displays larger scale restoration and protection projects throughout the watershed. This map demonstrates that the TCWC is active in all parts of the watershed, truly applying a watershed-wide approach to management of the health of Tryon Creek. Each individual section evaluates the impacts of these activities and identifies opportunities for restoration for the improvement of aquatic habitat for salmonids and other inhabitants of the Tryon Creek watershed. The following paragraphs summarize the key findings presented within each of the individual watershed assessment components. 


\section{Tryon Creek Watershed Council Watershed Restoration Projects}

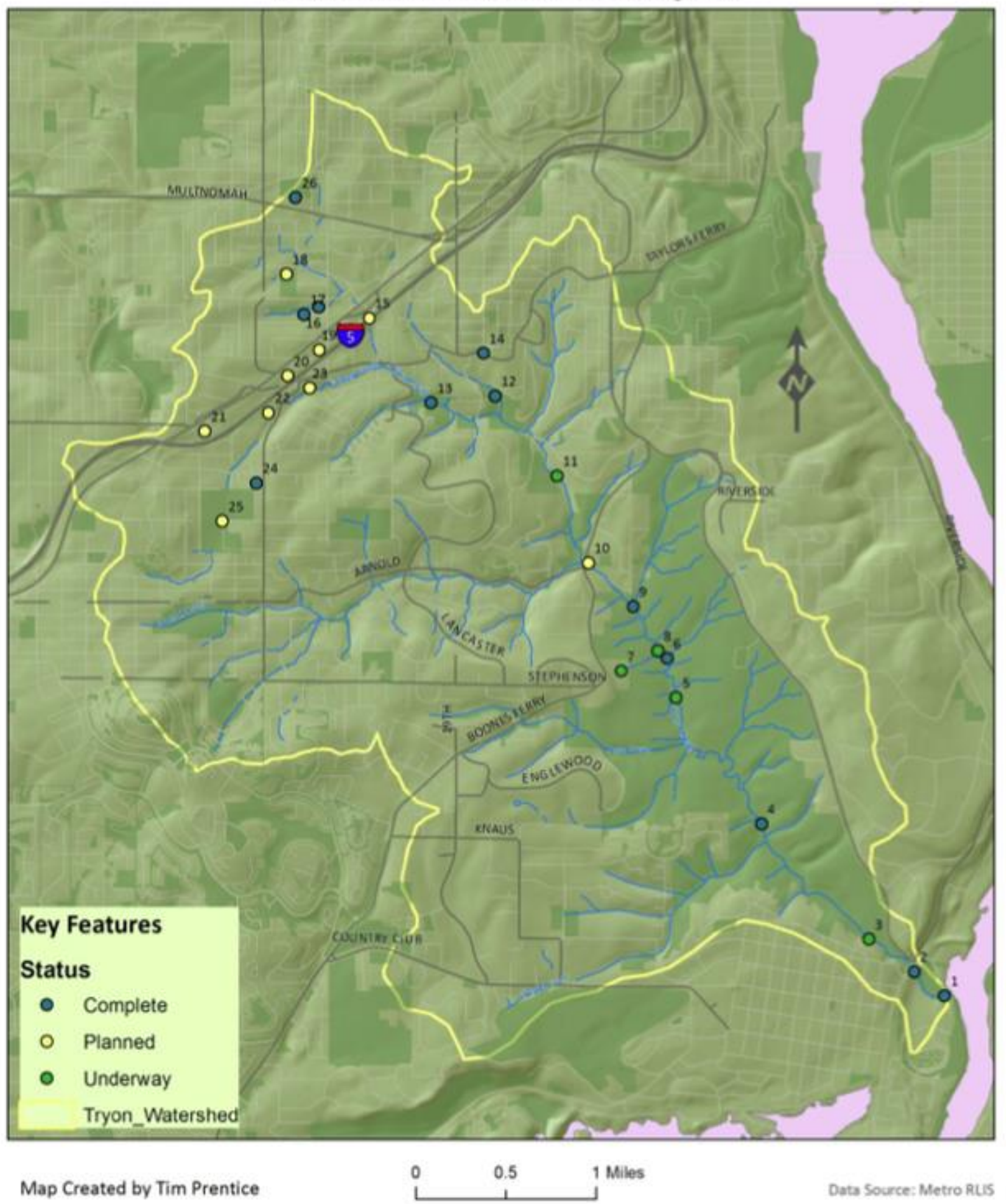

Figure 10.1 Map of restoration projects in various stages of completion throughout the Tryon Creek watershed (Source: Prentice, T.) 


\section{Key Findings}

\section{Historical Conditions}

The first human inhabitants of the Tryon Creek are those of the Clackamas Chinook, the WascoWishram, the Willamette Tumwater, the Multnomah, and other Chinookan peoples, as well as the Tualatin Kalapuya, the Cayuse, the Molalla and other tribes and bands of the Columbia and Willamette Rivers. Records of these people and their activities relevant to the history of the watershed are unfortunately sparse. It is suggested that local organizations prioritize the effort of learning about native inhabitants of Tryon Creek and the surrounding area through oral history and research. Further land settlement then began in the mid-1850s when families, including that of Socrates Tryon, were given land through the Donation Land Claim Act. Logging soon began to support the local iron smelting operations which sparked the development of Lake Oswego as a home for industry workers prior to being rebranded as a vacation spot for Portlanders in the early 190os. Through this time, sections the creek were diverted through pipes and culverts that continue to impact the habitat today. As development continued, neighbors came together to protect the forest within Tryon Creek State Natural Area in the 1970s, contributing to the health of the watershed. Today, local agencies and organizations, such as the Tryon Creek Watershed Council, focus efforts on the stewardship of the watershed through naturalization of stream segments and riparian vegetation work.

\section{Channel Habitat Types}

The evaluation of channel habitat types of Tryon Creek was made with few details and therefore could benefit from collection of new data for the purpose of targeted restoration. Characteristics observed throughout the stream channel are steep slopes, channel incision, and bank degradation. These characteristics can be attributed to the presence of impactful development within a watershed that has steep slopes and prone to landslides. Additionally, throughout sections of the watershed, the stream corridor is lined with landscaping and impervious surfaces that indirectly alter the structure of the stream bank. Actions that can restore channel structure toward a more natural state include improvement of channel meandering and daylighting at the headwaters and confluence. These are sections of the creek that have been most impacted by development through stream piping and diversion. It is advised that the Tryon Creek Watershed Council partner with the cities of Portland and Lake Oswego to educate neighbors about the history of the stream and opportunities for stewardship. Restoration of riparian habitat with native vegetation will also benefit in-stream habitat through prevention of erosion and stream bank stability.

\section{Hydrology and Water Use}

Understanding of hydrologic processes and land use effects are important for further ability to predict summer water temperatures, sediment transport, and other watershed geomorphic functions. The main issue associated with the hydrologic process of Tryon Creek is occurrence of peak flows during storms and low flows during dry months. Stormwater drainage patterns in the watershed influence the stream to have high flows following rain or storm events. This leads to erosion, introduction of sediments, and transport of woody debris and other habitat-forming materials. Low summer flows are harmful for fish and other species that rely on pool features for survival. Urban and residential land use have increased the frequency of high and low flows throughout the year. Restoration of stormwater drainage and inclusion of rain gardens and other beneficial infrastructure will benefit the health of Tryon Creek. Additionally, water rights data 
should be updated to include active diversions of water, including private landowner ponds and channels. This can be initiated by the Tryon Creek Watershed Council through a survey at an informative presentation regarding impacts of water diversion and continued through a door to door survey of residents.

\section{Riparian and Wetland Conditions}

Riparian vegetation is important for the biodiversity of the terrestrial aspect of a watershed as well as health of the stream. Benefits of intact riparian areas and wetlands for the stream include shading and providing large woody debris. Historic logging and recent development have altered the riparian environment, leaving the current primary canopy cover within the Tryon Creek State Natural Area being big leaf maple, Douglas fir and young to mid-aged western red cedar. Natural riparian habitat restoration is a large focus of the Tryon Creek Watershed Council (TCWC) and other local organizations throughout the watershed. The TCWC hosts events throughout the year to remove and replace invasive species, including the prolific English ivy. Ivy can overgrow trees and other vegetation, eventually smothering ground cover and felling trees due to the weight of biomass. It is suggested that land managers target ivy growing up tree trunks and smothering ground cover. Sensitive areas would be those with more recent introductions of the invasive plant species as well as those with heavy traffic and likelihood of spreading "hitchhiker" plants via boots or clothing. In addition to benefitting the riparian environment, community events targeted at invasive species removal educate residents and encourage them to continue to remove invasive species within their own properties. Riparian integrity is decreased in areas of concentrated development, especially the headwaters. Projects to remove invasive plant species and plant natives are key for enhancement of a diverse riparian habitat. Landowners can contribute to the native flora of the watershed by maintaining a Certified Backyard Habitat. The Backyard Habitat Certification Program is an effort designed by the Portland Audubon and Columbia Land Trust in an effort to create natural backyard habitats in the metro area (Portland Audubon, n.d.). Through the program, residents can work with a Habitat Technician to assess backyard habitat conditions and projects to encourage native vegetation and therefore supporting the surrounding ecosystem. Biodiversity and significant wetland environment are richest within the boundaries of the Tryon Creek State Natural Area. Wetlands assist with water storage as well as habitat for diverse plant and animals. Segments of the watershed that would most benefit from restoration of wetland habitat are the channeled headwaters and the confluence. It is suggested that the watershed council educate residents and help them to manage their land in ways that encourage meandering and wetland preservation. Native plant and terraced landscaping would increase water storage within the soil, rather than draining directly to the stream.

\section{Sediment Sources}

Tryon Creek is susceptible to sediment transport due to steep slopes, channel confinement, and concentrated development. Stormwater drainage diverted to the creek without water storage or filtration carries sediment and pollutants from roadways and other impervious surfaces. Fine sediments negatively impact aquatic organisms through smothering of rock surfaces and eggs as well as decreasing visibility. Many projects by the City of Portland target improvement of roadways and parking lots to increase water storage and filtration as it moves downstream to the creek. Recommendations for reduction of impacts of fine sediments include conservation of productive riparian environments and improvement of stormwater drainage from public and private facilities. Bio-swales and rain gardens provide water storage and filtrations for the runoff before entering the 
stream system. Figure 10.2 is an image of a bio-swale improvement on a public road within the Tryon Creek watershed.

An assessment of stormwater drainage on private land within the watershed would fill a large data gap. Through the acquisition of this knowledge, prioritization of private and public land restoration could take place. An educational community event would provide the opportunity for residents to learn about the impacts of fine sediments and pollutants carried in stormwater and gain resources for improvement of landscaping and drainage to benefit the health of the watershed. Due to steep slopes throughout the watershed, terraced landscaping would slow runoff flow and filter water as it moves downslope toward the creek. Additionally, it would be useful to conduct a street drainage system assessment of the entire watershed, including streets within the city of Lake Oswego. This would provide an understanding of watershed-wide impacts and further opportunity for restoration prioritization.

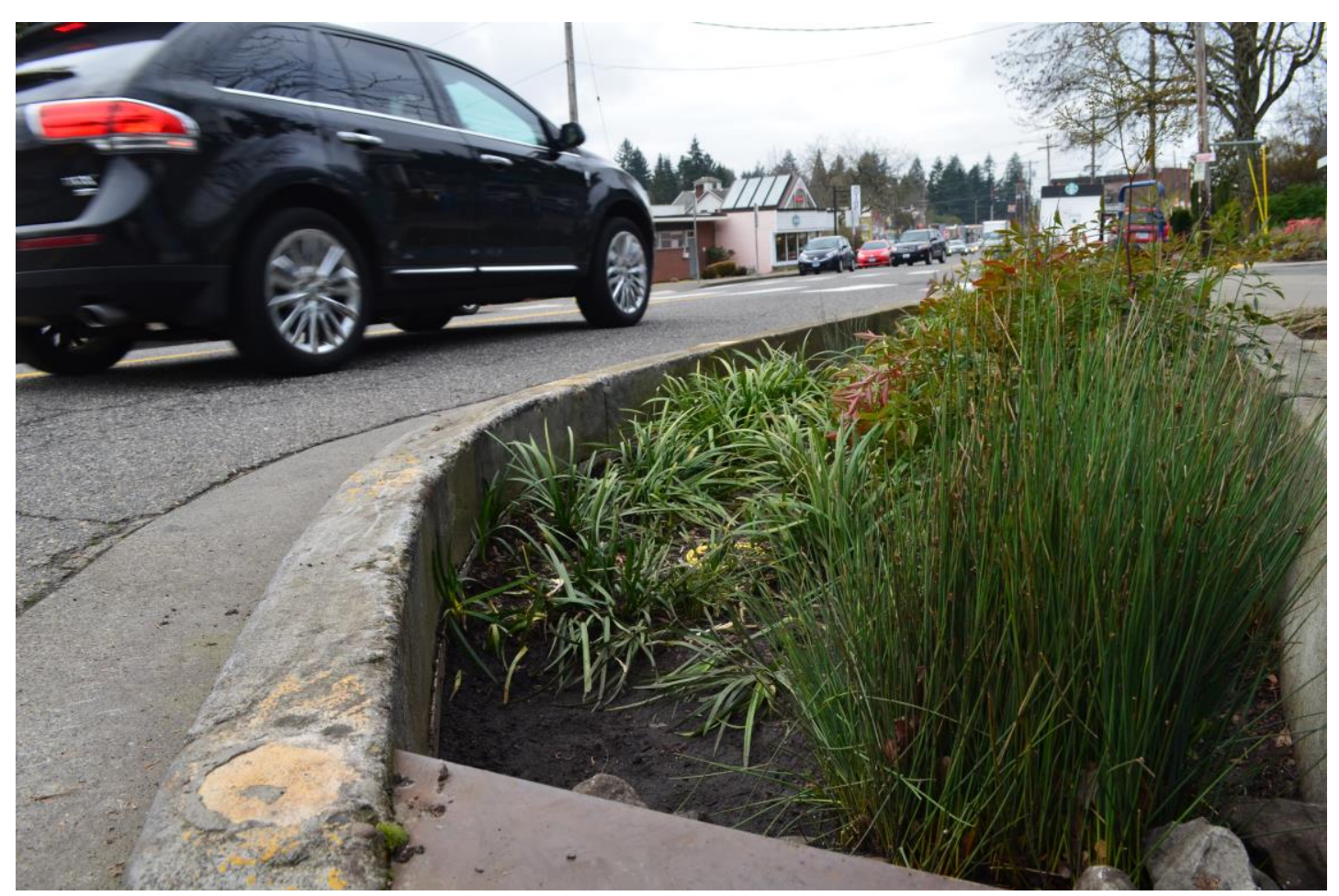

Figure 10.2 Bio-swales with low maintenance native vegetation improve roadside aesthetic while providing water storage and filtration services (Source: Barton, A.).

\section{Channel Modifications}

Development of Tryon Creek historically occurred without consideration of the health of the watershed and its aquatic organisms. The creek has been diverted through piping and culverts throughout its length. The culverts of Boones Ferry Rd and Hwy 43 have been identified as highly impactful for fish passage and are prioritized for improvement. When planning replacement of culverts, it is also important to consider challenges that the creek may face as a result. Sediment currently held in place upstream of culverts will be disturbed and washed downstream. Relocation of lamprey and other sediment dwelling organisms may reduce negative population impacts during construction of the Hwy 43 culvert. Restructuring of these culverts, daylighting sections, and improvement of floodplains would benefit the health of the aquatic habitat of Tryon Creek. Specifically, the headwaters of Tryon Creek were largely disregarded during development, leading 
to piping of stream channels that should be day-lighted to be enjoyed by the wildlife and human community. The confluence with the Willamette River is a section of the creek that has been channelized and would benefit from meandering and rehabilitation of the floodplain zone. This restoration would increase storm resilience by giving water more space to flow before flooding residential areas as well as provide key habitat for aquatic organisms.

\section{Water Quality}

Tryon Creek is $303(\mathrm{~d})$ listed for biological criteria, dissolved oxygen, and temperature. Sensitive beneficial uses of the watershed include salmon spawning and rearing which are highly responsive to changes of these factors. Projects to decrease temperature maximums should focus on increasing riparian vegetation shading, especially in urban areas of the watershed. Preservation of cool temperatures at the headwaters through shading riparian environment and healthy stream habitat will have downstream effects on water temperature. Through efforts to encourage a native riparian environment and allowing the stream to meander naturally on private and public land surrounding the stream, temperature, dissolved oxygen, and other water quality parameters would benefit. Additionally, protection of the environment within the state natural area would continue to serve as a positive impact on the entire watershed. Conservation of riparian environment and complex stream networks within the state natural area provide cooling benefits for the watershed as a whole. It is suggested that the watershed council, OPRD, and other organizations continue efforts to plant native species in this area and throughout the Tryon Creek watershed. Woody debris resulting from a prolific riparian environment would also provide channel complexity, contributing to the restoration of the stream for reduced temperature. The dissolved oxygen and biological criteria parameters have less data to steer restoration priorities. Yet, colder, fast moving water with few pollutant influences can typically retain more oxygen indicating that stormwater drainage improvements and channel restoration would also be effective for the purpose of increasing dissolved oxygen. Growth of riparian vegetation would additionally provide shading and structural support for the stream channel.

\section{Fish and Fish Habitat}

Salmonid and other fish species are observed in Tryon Creek downstream of the Hwy 43 culvert and it is concluded that they would move upstream if given the opportunity. Larval lamprey were also caught downstream of the Hwy 43 culvert during samples between 2005 and 2012. The primary action that would benefit salmon distribution throughout Tryon Creek would be restructuring of the Hwy 43 and Boones Ferry Road culverts. Removing this fish passage barrier would provide habitat and other useful resources to key species that historically used Tryon Creek for habitat. Improvement of channel complexity will also make the stream more habitable through maintenance of large woody debris and pool-riffle options. Another suggestion for retention of stream structure is the survey of and encouragement of beaver habitat. Beaver dams decrease stream velocity, effectively decreasing channel erosion and providing habitat for many other species within the channel, including salmonid species (Petro, et al., 2015). Beaver introduction would be most beneficial in the portion downstream of the Hwy 43 culvert because that is where the majority of fish populations were found. If fish are able to be reintroduced upstream of the culvert (after culvert replacement), then the Tryon Creek State Natural Area would also make an ideal habitat for beaver because it is relatively more natural and undisturbed when compared to residential and urban sections of the watershed. 


\section{Conclusion}

Tryon Creek and its surrounding ecosystem provide habitat, water filtration, aesthetic, and many other benefits for wildlife and humans of the community. Actions of local agencies, landowners, and residents within a watershed contribute to the health of the stream. Seemingly small changes such as landscaping can have large downstream effects. Consideration of Tryon Creek is key for future land management decisions. This watershed assessment aims to compile knowledge, identify data gaps, and prioritize stewardship efforts. It is intended that the audience apply this information for a watershed-based approach to management and conservation within the Tryon Creek watershed. Actions that landowners should take to protect the resources of the watershed are to work with the Tryon Creek Watershed Council to remove invasive plant species and integrate native vegetation into landscaping that can provide shading for the stream, bank stability, and prevent erosion of fine sediments. This would also increase wildlife corridor expansion, improving biodiversity throughout the watershed. Additionally, private and public facilities should install rain gardens and similar infrastructure that slows stormwater drainage, allowing soils to store and filter the runoff before it enters the stream system. Channel complexity can be improved throughout the watershed by encouragement of natural meandering of the stream, maintenance of large woody debris and diverse substrates in the channel. Additionally, protection of existing beaver habitat as well as further spread of beaver throughout the watershed would provide stream channel structure, woody material, and habitat for other species including salmonids. Public efforts to improve stormwater drainage from large roadways should continue to positively impact Tryon Creek and inspire private landowners to drainage from their properties as well. Through community education and further data collection, the Tryon Creek Watershed Council and other organizations can continue to conserve the natural habitat of the watershed for future generations of wildlife and humans. It is key that private and public landowners are informed of their connections to the watershed and make land use changes that benefit the water resources. Informed community members will also ideally vote and perform stewardship efforts that benefit the watershed. Stewardship and educational events that the Tryon creek Watershed Council hosts throughout the year help community members to connect with others in engagement that benefits the watershed.

\section{References}

Barton, A. (2019). Image of bio-swale within the Tryon Creek watershed. Tryon Creek Watershed Council.

Petro, V., et al. (2015). Evaluating landowner-based beaver relocation as a tool to restore salmon habitat. Global Ecology and Conservation. Volume 3, pages 477-486.

Portland Audubon (n.d.). Backyard Habitat Certification Program. Accessed at https://audubonportland.org/get-involved/backyard-habitat-certification-program/

Prentice, T. (2013). Tryon Creek Watershed Council Watershed Restoration Projects. Christina Friedle Portland Community College course. 